\title{
Iron-Catalyzed Polymerization of Isoprene and Other 1,3-Dienes
}

\section{Citation}

Raynaud, Jean, Jessica Y. Wu, and Tobias Ritter. 2012. Iron-catalyzed polymerization of isoprene and other 1,3-Dienes. Angewandte Chemie 124(47): 11975-11978.

\section{Published Version}

doi:10.1002/ange.201205152

\section{Permanent link}

http://nrs.harvard.edu/urn-3:HUL.InstRepos:10861168

\section{Terms of Use}

This article was downloaded from Harvard University's DASH repository, and is made available under the terms and conditions applicable to Open Access Policy Articles, as set forth at http:// nrs.harvard.edu/urn-3:HUL.InstRepos:dash.current.terms-of-use\#OAP

\section{Share Your Story}

The Harvard community has made this article openly available.

Please share how this access benefits you. Submit a story.

Accessibility 
Supporting Information

\title{
Iron-Catalyzed Polymerization of Isoprene and Other 1,3-Dienes
}

\author{
Jean Raynaud, Jessica Y. Wu and Tobias Ritter* \\ Department of Chemistry and Chemical Biology, Harvard University \\ 12 Oxford St., Cambridge, Massachusetts 02138 \\ E-mail: ritter@chemistry.harvard.edu
}




\section{Table of Contents}

NMR Spectra

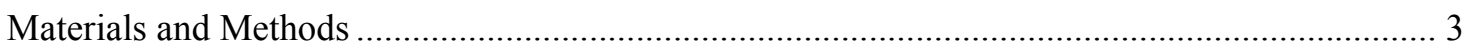

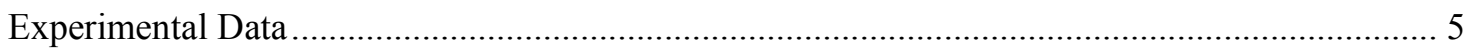

Experimental Procedures and Compound Characterization ................................................. 5

(E)-2,4,4-Trimethyl- $N$-(pyridin-2-ylmethylene)pentan-2-amine (S1) ............................. 5

(E)-2,4,4-Trimethyl- $N$-(pyridin-2-ylmethylene)pentan-2-amine iron(II) chloride (1) ............ 5

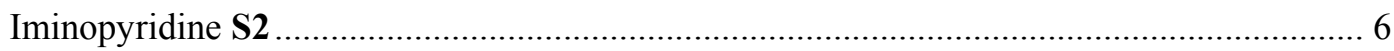

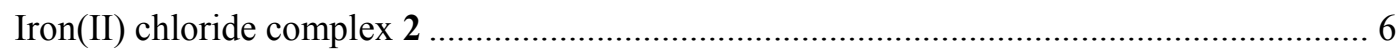

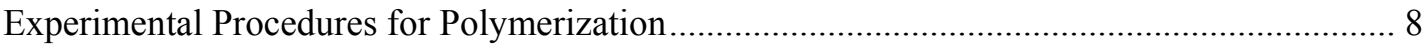

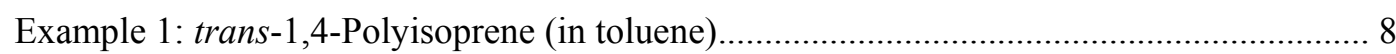

Example 2: trans-1,4-Polyisoprene (higher molar mass in Me-cyclohexane/toluene 5:1) ..... 8

Example 3: trans-1,4-Polyisoprene (in heptane/toluene 5:1) ............................................. 9

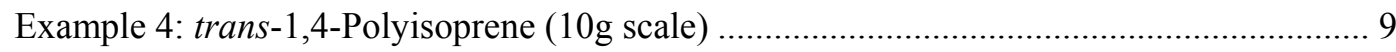

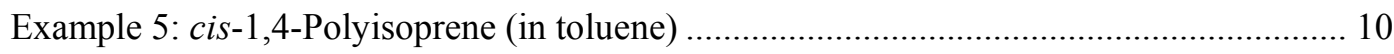

Example 6: cis-1,4-Polyisoprene (in Me-cyclohexane at room temperature) ......................... 10

Example 7: cis-1,4-Polyisoprene (in toluene at room temperature) .....................................11

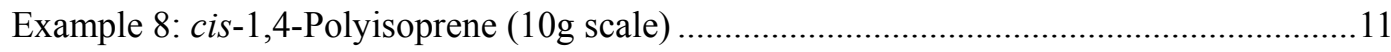

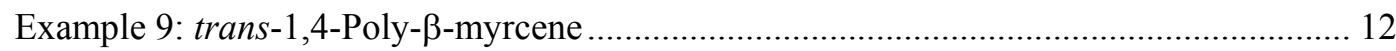

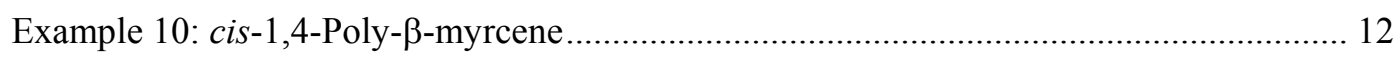

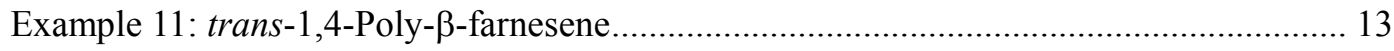

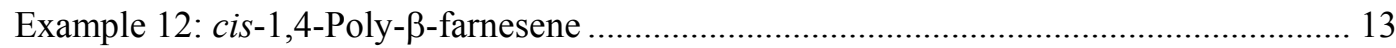

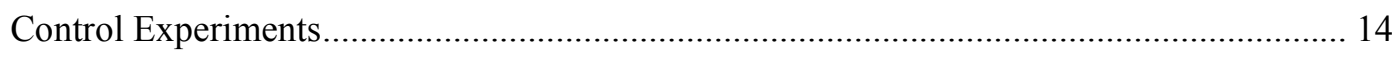

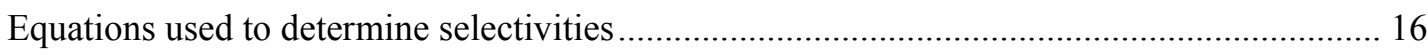

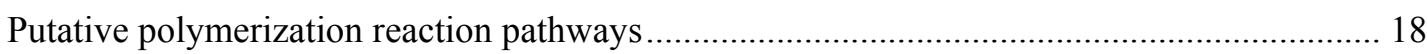

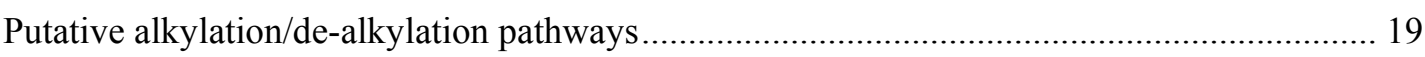

Different isomeric motifs obtained during isoprene polymerization........................................ 19

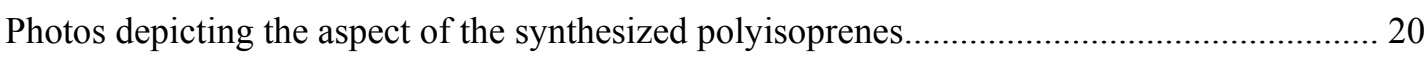

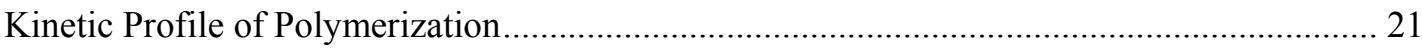

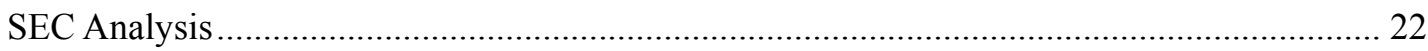

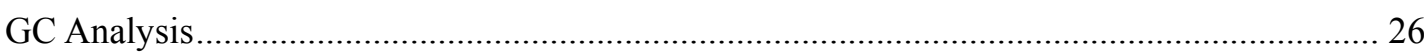

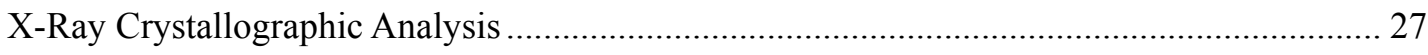

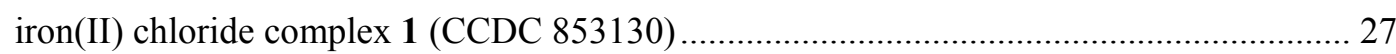

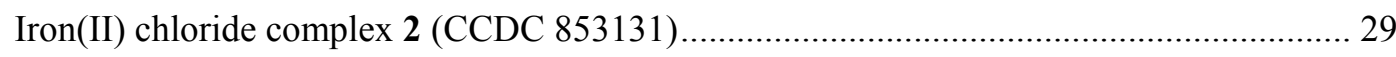

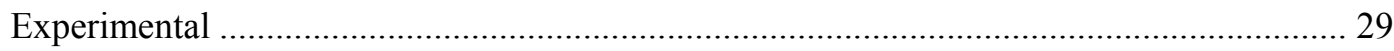

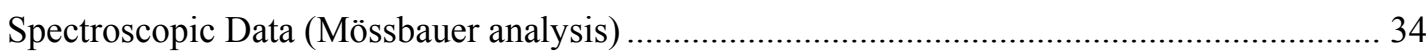

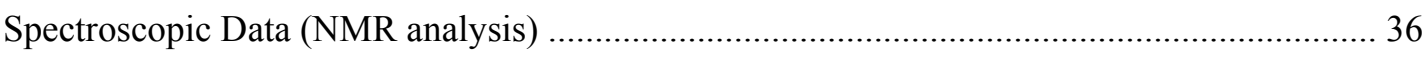

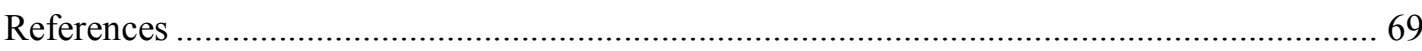




\section{NMR Spectra}

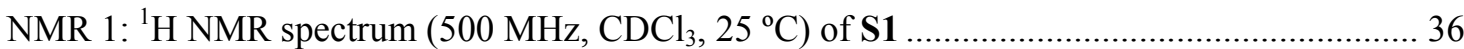

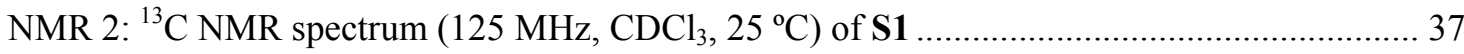

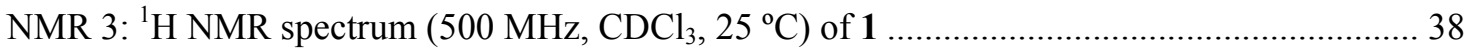

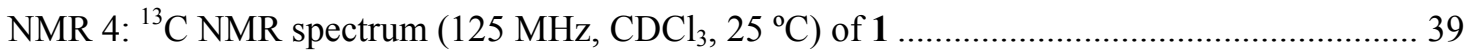

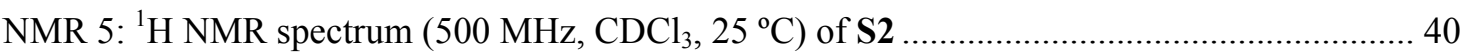

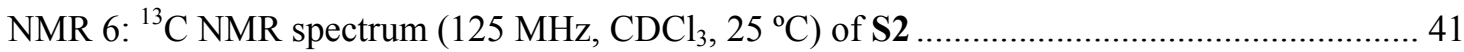

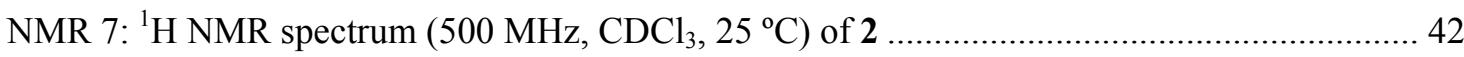

NMR 8: ${ }^{1} \mathrm{H}$ NMR spectrum $\left(500 \mathrm{MHz}, \mathrm{CDCl}_{3}, 25^{\circ} \mathrm{C}\right)$ of cis-1,4-polyisoprene (ex. 5) ............... 43

NMR 9: ${ }^{13} \mathrm{C}$ NMR spectrum $\left(125 \mathrm{MHz}, \mathrm{CDCl}_{3}, 25^{\circ} \mathrm{C}\right)$ of cis-1,4-polyisoprene (ex. 5) .............. 44

NMR 10: ${ }^{13} \mathrm{C}$ NMR spectrum (125 MHz, $\left.\mathrm{CDCl}_{3}, 25{ }^{\circ} \mathrm{C}\right)$ of cis-1,4-polyisoprene (aliphatic

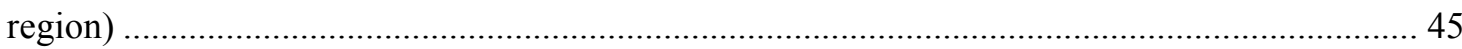

NMR 11: ${ }^{13} \mathrm{C}$ NMR spectrum (125 MHz, $\left.\mathrm{CDCl}_{3}, 25^{\circ} \mathrm{C}\right)$ of cis-1,4-polyisoprene (olefinic region)

46

NMR 12: ${ }^{1} \mathrm{H}$ NMR spectrum $\left(500 \mathrm{MHz}, \mathrm{CDCl}_{3}, 25^{\circ} \mathrm{C}\right)$ of trans-1,4-polyisoprene (ex. 2) ........ 47

NMR 13: ${ }^{1} \mathrm{H}$ NMR spectrum $\left(500 \mathrm{MHz}, \mathrm{CDCl}_{3}, 25^{\circ} \mathrm{C}\right)$ of trans-1,4-polyisoprene (ex. 1) ........ 48

NMR 14: ${ }^{13} \mathrm{C}$ NMR spectrum $\left(125 \mathrm{MHz}, \mathrm{CDCl}_{3}, 25{ }^{\circ} \mathrm{C}\right)$ of trans-1,4-polyisoprene (ex. 2) ....... 49

NMR 15: ${ }^{13} \mathrm{C}$ NMR spectrum $\left(125 \mathrm{MHz}, \mathrm{CDCl}_{3}, 25{ }^{\circ} \mathrm{C}\right)$ of trans-1,4-polyisoprene (aliphatic

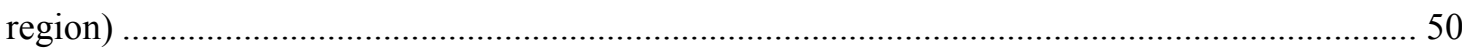

NMR 16: ${ }^{13} \mathrm{C}$ NMR spectrum $\left(125 \mathrm{MHz}, \mathrm{CDCl}_{3}, 25{ }^{\circ} \mathrm{C}\right)$ of trans-1,4-polyisoprene (full) ......... 51

NMR 17: ${ }^{13} \mathrm{C}$ NMR spectrum $\left(125 \mathrm{MHz}, \mathrm{CDCl}_{3}, 25{ }^{\circ} \mathrm{C}\right)$ of trans-1,4-polyisoprene (olefinic

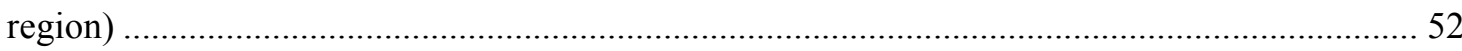

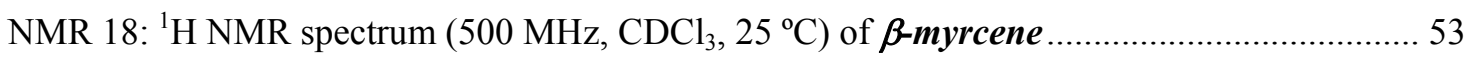

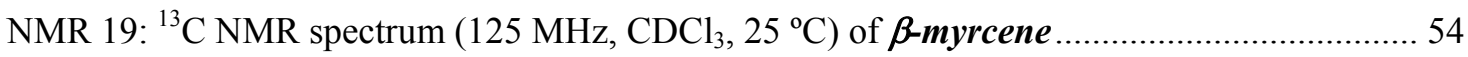

NMR 20: ${ }^{1} \mathrm{H}$ NMR spectrum $\left(500 \mathrm{MHz}, \mathrm{CDCl}_{3}, 25^{\circ} \mathrm{C}\right)$ of farnesene (mixture) ............................ 55

NMR 21: ${ }^{13} \mathrm{C}$ NMR spectrum $\left(125 \mathrm{MHz}, \mathrm{CDCl}_{3}, 25^{\circ} \mathrm{C}\right)$ of farnesene (mixture) .......................... 56

NMR 22: ${ }^{1} \mathrm{H}$ NMR spectrum ( $500 \mathrm{MHz}, \mathrm{CDCl}_{3}, 25^{\circ} \mathrm{C}$ ) of farnesene ( $\alpha$-isomer) (ex. 10) ......... 57

NMR 23: ${ }^{1} \mathrm{H}$ NMR spectrum ( $500 \mathrm{MHz}, \mathrm{CDCl}_{3}, 25^{\circ} \mathrm{C}$ ) of farnesene ( $\alpha$-isomer) (ex. 9) ........... 58

NMR 24: ${ }^{13} \mathrm{C}$ NMR spectrum $\left(125 \mathrm{MHz}, \mathrm{CDCl}_{3}, 25^{\circ} \mathrm{C}\right)$ of farnesene ( $\alpha$-isomer)....................... 59

NMR 25: ${ }^{1} \mathrm{H}$ NMR spectrum ( $500 \mathrm{MHz}, \mathrm{CDCl}_{3}, 25^{\circ} \mathrm{C}$ ) of trans-1,4-poly- $\boldsymbol{\beta}$-myrcene (ex. 9) .... 60

NMR 26: ${ }^{13} \mathrm{C}$ NMR spectrum $\left(125 \mathrm{MHz}, \mathrm{CDCl}_{3}, 25^{\circ} \mathrm{C}\right)$ of trans-1,4-poly- $\boldsymbol{\beta}$-myrcene (ex. 9) ... 61

NMR 27: ${ }^{1} \mathrm{H}$ NMR spectrum $\left(500 \mathrm{MHz}, \mathrm{CDCl}_{3}, 25^{\circ} \mathrm{C}\right)$ of cis-1,4-poly- $\boldsymbol{\beta}$-myrcene (ex. 10) ...... 62

NMR 28: ${ }^{13} \mathrm{C}$ NMR spectrum $\left(125 \mathrm{MHz}, \mathrm{CDCl}_{3}, 25^{\circ} \mathrm{C}\right)$ of cis-1,4-poly- $\boldsymbol{\beta}$-myrcene (ex. 10) ..... 63

NMR 29: ${ }^{1} \mathrm{H}$ NMR spectrum $\left(500 \mathrm{MHz}, \mathrm{CDCl}_{3}, 25^{\circ} \mathrm{C}\right)$ of trans-1,4-poly- $\boldsymbol{\beta}$-farnesene (ex. 11) 64

NMR 30: ${ }^{1} \mathrm{H}$ NMR spectrum $\left(500 \mathrm{MHz}, \mathrm{CDCl}_{3}, 25^{\circ} \mathrm{C}\right)$ of trans-1,4-poly- $\beta$-farnesene (ex. 11) 65

NMR 31: ${ }^{13} \mathrm{C}$ NMR spectrum $\left(125 \mathrm{MHz}, \mathrm{CDCl}_{3}, 25^{\circ} \mathrm{C}\right)$ of trans-1,4-poly- $\boldsymbol{\beta}$-farnesene (ex. 11) 66

NMR 32: ${ }^{1} \mathrm{H}$ NMR spectrum $\left(500 \mathrm{MHz}, \mathrm{CDCl}_{3}, 25^{\circ} \mathrm{C}\right)$ of cis-1,4-poly- $\beta$-farnesene (ex. 12) .... 67

NMR 33: ${ }^{13} \mathrm{C}$ NMR spectrum $\left(125 \mathrm{MHz}, \mathrm{CDCl}_{3}, 25^{\circ} \mathrm{C}\right)$ of cis-1,4-poly- $\boldsymbol{\beta}$-farnesene (ex. 12) ... 68 


\section{Materials and Methods}

All reactions were carried out under an inert atmosphere (nitrogen) using standard techniques for manipulating air-sensitive compounds unless otherwise stated. ${ }^{1}$ All glassware was stored in an oven or was flame-dried prior to use under an inert atmosphere of nitrogen or argon as stated. Anhydrous solvents were obtained either by filtration through drying columns ${ }^{2}\left(\mathrm{CH}_{2} \mathrm{Cl}_{2}\right)$ on an $\mathrm{mBraun}$ system or by distillation over sodium/benzophenone $\left(\mathrm{Et}_{2} \mathrm{O}\right.$, toluene, pentane, heptane, methylcyclohexane). Analytical thin-layer chromatography (TLC) was performed on EMD TLC plates pre-coated with $250 \mu \mathrm{m}$ thickness silica gel 60 F254 plates visualized by fluorescence quenching under UV light and stained using potassium permanganate stain. Flash chromatography was performed on Silicycle silica gel $60(40-63 \mu \mathrm{m})$ using a forced flow of eluent at $0.3-0.5$ bar pressure. ${ }^{3}$ Yields refer to purified and spectroscopically pure compounds (all polymers are spectroscopically pure with the exception of polyfarnesenes where traces of monomers, precipitated with the bulk, remain). ${ }^{1} \mathrm{H}$ NMR spectra were recorded on a Varian Unity/Inova 500 spectrometer operating at $500 \mathrm{MHz} .{ }^{13} \mathrm{C}$ NMR spectra were recorded on a Varian Unity/Inova 500 spectrometer operating at $125 \mathrm{MHz} .10$ seconds and 5 seconds were used as relaxation times for ${ }^{1} \mathrm{H} \mathrm{NMR}$ and ${ }^{13} \mathrm{C} \mathrm{NMR}$, respectively, for the determination of selectivities in polymerization reactions. Prior to use, $\mathrm{CDCl}_{3}$ was passed through a plug of basic alumina and $\mathrm{CD}_{2} \mathrm{Cl}_{2}$ was degassed by the freeze-pump-thaw method ${ }^{4}$ and dried over $4 \AA$ molecular sieves. Chemical shifts are reported in parts per million from tetramethylsilane with the solvent resonance as the internal standard. For ${ }^{1} \mathrm{H} N \mathrm{NM}: \mathrm{CDCl}_{3}=\delta 7.26 \mathrm{ppm}, \mathrm{CD}_{2} \mathrm{Cl}_{2}: \delta 5.32 \mathrm{ppm}$. For ${ }^{13} \mathrm{C}$ NMR: $\mathrm{CDCl}_{3}=\delta 77.16 \mathrm{ppm}, \mathrm{CD}_{2} \mathrm{Cl}_{2}=\delta 53.80 \mathrm{ppm}$. Data are reported as follows: chemical shift, multiplicity $(\mathrm{s}=$ singlet, $\mathrm{d}=$ doublet, $\mathrm{t}=$ triplet, $\mathrm{q}=$ quartet, $\mathrm{m}=$ multiplet and $\mathrm{br}=$ broad), coupling constant in $\mathrm{Hz}$, and integration. For paramagnetic molecules, the ${ }^{1} \mathrm{H} \mathrm{NMR}$ and ${ }^{13} \mathrm{C}$ NMR data are reported with the chemical shift followed by the peak width at half-height in Hz. Magnetic susceptibility measurements for all iron complexes were obtained using the Evans method $^{5}$ and are reported as follows: (field strength, solvent): $\mu_{\text {eff }}$ (concentration in $\mathrm{mg} / \mathrm{mL}$ ). ${ }^{57} \mathrm{Fe}$ Mössbauer spectra were measured with a constant acceleration spectrometer (SEE Co, Minneapolis, MN). Isomer shifts are quoted relative to Fe metal at room temperature. Data was analyzed and simulated with WMOSS software (Web Research Corp., Edina, MN). Elemental analysis was performed by Robertson Microlit Laboratories (Madison, NJ). Mass spectra were

\footnotetext{
${ }^{1}$ Shriver, D. F.; Drezdon, M. A. Inert-Atmosphere Glove Boxes. The Manipulation of Air-Sensitive Compounds, 2nd ed.; John Wiley \& Sons: New York, 1986; pp. 45-67.

${ }^{2}$ Pangborn, A. B.; Giardello, M. A.; Grubbs, R. H.; Rosen, R. K.; Timmers, F. J. Organometallics 1996, 15, 1518 1520 .

${ }^{3}$ Still, W. C.; Kahn, M.; Mitra, A. J. Org. Chem. 1978, 43, 2923-2925.

4 Armarego, W. L. F.; Chai, C. L. L. Purification of Laboratory Chemicals, 5th ed.; Butterworth Henemann: Amsterdam, 2003; pp. 29-30.

${ }^{5}$ Evans, D. F. J. Chem. Soc. 1959, 2003-2005.
} 
obtained at the Harvard University Mass Spectrometry Facilities. High resolution mass spectra were obtained on an Agilent 6210 Time-of-Flight LC/MS or an Agilent 1100 ESI attached to a Bruker Daltonics MicrOTOF-Q II. Bulb-to-bulb distillation was carried out using a Büchi B-585 Kugelrohr. Molar masses of polyisoprenes were determined using size exclusion chromatography with a Varian GPC, fitted with a 3-column set and a RI detector, using THF as the eluent and polystyrenes as standards (Grinstaff group, Boston University). SEC chromatography data are reported as average polar mass in weight $\left(M_{w}\right)$ in $\mathrm{g} / \mathrm{mol}$ and polydispersity $(D)$. Gas chromatography was performed on a Shimadzu GC-2014 equipped with an AOC-20i auto-injector and a set of hydrophobic columns (Restec Rtx-200MS, Crossbond trifluoropropylmethyl polysiloxane, 30 meter $0.25 \mathrm{mmID}, 1 \mu \mathrm{m} \mathrm{df}$ ). Temperature ramps were realized between $170^{\circ} \mathrm{C}$ and $250^{\circ} \mathrm{C}$ to separate the different isomers of farnesene.

Reagents: All reagents were purchased from standard commercial sources (Aldrich, Strem, Alfa Aesar or TCI) and used as received unless otherwise noted. 2-pyridinecarboxaldehyde (Aldrich, 98\%) was distilled prior to use. 2,2,4-pentane-2-amine (Aldrich, 97\%) was distilled prior to use. Supermesitylamine (Aldrich, 98\%) was used as received. Iron(II) chloride (98\% Aldrich or 99.99\% Strem) was u0sed as received. Trityl tetrakis(pentafluorophenyl)borate (bright yellow powder, 98\%, Strem) was used as received. Isoprene (99\%, Alfa Aesar or TCI) was distilled over $(n-\mathrm{Bu})_{2} \mathrm{Mg}$ or $\mathrm{Al}(i-\mathrm{Bu})_{3}$ and degassed by the freeze-pump-thaw method ${ }^{4}$ prior to use. Myrcene was distilled over $\mathrm{Al}(i-\mathrm{Bu})_{3}$ and degassed by the freeze-pump-thaw method ${ }^{4}$ prior to use. Farnesene was used as received as the isomer mixture ( $Z$ - and $E$ - $\beta$-farnesene as well as $Z$ - and $E$ $\alpha$-farnesene). Trimethylaluminum, triethylaluminum and tri-isobutylaluminum were purchased neat in metallic canisters from Aldrich (97\%, 93\%, and 95\% purity, respectively). Trialkylaluminum alkylating reagents were either cannula-transferred from storage tanks and used as is or redistilled prior to use (no major difference was observed). 


\section{Experimental Data}

\section{Experimental Procedures and Compound Characterization}<smiles>O=Cc1ccccn1</smiles><smiles>[BH3-]</smiles><smiles>CC(C)(C)CC(C)(C)N</smiles>

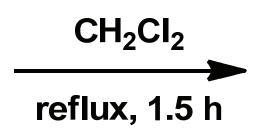

$94 \%$ yield

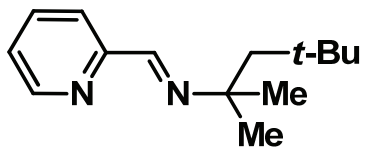

S1

\section{(E)-2,4,4-Trimethyl- $N$-(pyridin-2-ylmethylene)pentan-2-amine (S1)}

In air, to a solution of 2-pyridinecarboxaldehyde $(0.338 \mathrm{~g}, 0.300 \mathrm{~mL}, 3.15 \mathrm{mmol}, 1.01$ equiv $)$ in $\mathrm{CH}_{2} \mathrm{Cl}_{2}(10 \mathrm{~mL})$ was added 2,4,4-trimethylpentane-2-amine $(0.402 \mathrm{~g}, 0.500 \mathrm{~mL}, 3.11 \mathrm{mmol}, 1.00$ equiv). After heating at reflux for $1.5 \mathrm{~h}$ with azeotropic removal of water using a Dean-Stark trap, the reaction mixture was concentrated under reduced pressure. The residue was purified by bulb-to-bulb distillation $\left(250 \mathrm{mTorr}, 140{ }^{\circ} \mathrm{C}\right)$ to give the title compound as colorless oil $(0.639 \mathrm{~g}$, 94\% yield).

NMR Spectroscopy: ${ }^{1} \mathrm{H}$ NMR (500 MHz, $\left.\mathrm{CDCl}_{3}, 25^{\circ} \mathrm{C}, \delta\right): 8.61(\mathrm{dt}, J=4.9,1.0 \mathrm{~Hz}, 1 \mathrm{H}), 8.33$ (s, $1 \mathrm{H}), 8.03(\mathrm{dt}, J=7.8,1.0 \mathrm{~Hz}, 1 \mathrm{H}), 7.71(\mathrm{~m}, 1 \mathrm{H}), 7.26$ (ddd, $J=7.8,4.9,1.0 \mathrm{~Hz}, 1 \mathrm{H}), 1.70(\mathrm{~s}$, $2 \mathrm{H}), 1.33(\mathrm{~s}, 6 \mathrm{H}), 0.94(\mathrm{~s}, 9 \mathrm{H}) .{ }^{13} \mathrm{C} \mathrm{NMR}\left(125 \mathrm{MHz}, \mathrm{CDCl}_{3}, 25{ }^{\circ} \mathrm{C}, \delta\right): 156.0,155.9,149.3$, 136.6, 124.4, 120.8, 61.6, 56.6, 32.2, 31.9, 29.7. HRMS-ESI $(\mathrm{m} / \mathrm{z})$ : Calcd for $\left[\mathrm{C}_{14} \mathrm{H}_{22} \mathrm{~N}_{2}+\mathrm{H}\right]$, 219.1856. Found, 219.1854.

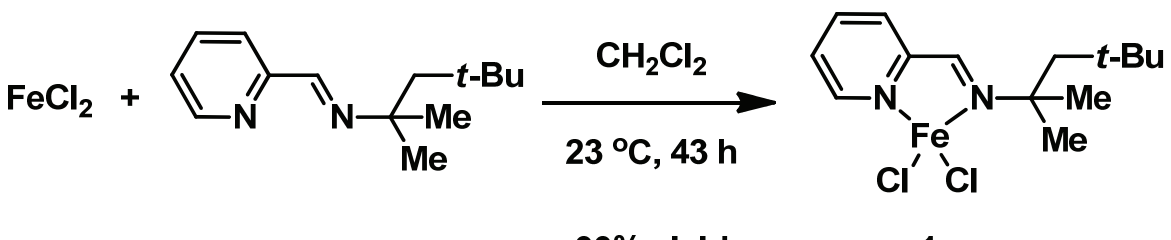

$99 \%$ yield

1

\section{(E)-2,4,4-Trimethyl- $N$-(pyridin-2-ylmethylene)pentan-2-amine iron(II) chloride (1)}

A solution of (E)-2,4,4-trimethyl- $N$-(pyridin-2-ylmethylene)propan-2-amine (S1), (0.300 g, 1.37 mmol, 1.00 equiv) in $\mathrm{CH}_{2} \mathrm{Cl}_{2}(8 \mathrm{~mL})$ was added to iron(II) chloride (174 mg, $1.37 \mathrm{mmol}, 1.00$ equiv). The reaction mixture was stirred at $23{ }^{\circ} \mathrm{C}$ for $43 \mathrm{~h}$. The reaction mixture was filtered over a celite pad, eluting with $\mathrm{CH}_{2} \mathrm{Cl}_{2}$, and the filtrate was concentrated under reduced pressure. The residue was washed with $\mathrm{Et}_{2} \mathrm{O}(2 \times 5 \mathrm{~mL})$ and dried under reduced pressure to afford the title compound as an orange solid $(0.471 \mathrm{~g}, 99 \%$ yield). X-Ray quality crystals were grown from vapor diffusion of pentane $(3 \mathrm{~mL})$ into a solution $\left(1 \mathrm{~mL}, 10 \mathrm{mg}\right.$ ) of the title compound in $\mathrm{CH}_{2} \mathrm{Cl}_{2}$ at $23{ }^{\circ} \mathrm{C}$ (use a $4-\mathrm{mL}$ straight-walled vial in a $20-\mathrm{mL}$ capped vial).

Magnetic susceptibility (500 MHz, $\left.\mathrm{CD}_{2} \mathrm{Cl}_{2}\right): \mu_{\text {eff }}=5.45 \mu_{\mathrm{B}}(8.43 \mathrm{mg} / \mathrm{mL})$. NMR Spectroscopy: ${ }^{1} \mathrm{H}$ NMR $\left(500 \mathrm{MHz}, \mathrm{CD}_{2} \mathrm{Cl}_{2}, 25{ }^{\circ} \mathrm{C}, \delta\right): 82.92\left(\Delta v_{1 / 2}=258 \mathrm{~Hz}\right), 64.16\left(\Delta v_{1 / 2}=702 \mathrm{~Hz}\right), 57.30$ $\left(\Delta v_{1 / 2}=77 \mathrm{~Hz}\right), 52.50\left(\Delta v_{1 / 2}=61 \mathrm{~Hz}\right),-3.23\left(\Delta v_{1 / 2}=82 \mathrm{~Hz}\right),-15.99\left(\Delta v_{1 / 2}=334 \mathrm{~Hz}\right),-17.94$ 
$\left(\Delta v_{1 / 2}=39 \mathrm{~Hz}\right),-24.21\left(\Delta v_{1 / 2}=550 \mathrm{~Hz}\right) \cdot{ }^{13} \mathrm{C} \mathrm{NMR}\left(125 \mathrm{MHz}, \mathrm{CD}_{2} \mathrm{Cl}_{2}, 25{ }^{\circ} \mathrm{C}, \delta\right): 298.8\left(\Delta v_{1 / 2}=\right.$ $296 \mathrm{~Hz}), 246.7\left(\Delta v_{1 / 2}=89 \mathrm{~Hz}\right), 245.4\left(\Delta v_{1 / 2}=84 \mathrm{~Hz}\right), 142.6\left(\Delta v_{1 / 2}=97 \mathrm{~Hz}\right), 111.7\left(\Delta v_{1 / 2}=252\right.$ $\mathrm{Hz}), 107.5\left(\Delta v_{1 / 2}=208 \mathrm{~Hz}\right), 78.5\left(\Delta v_{1 / 2}=153 \mathrm{~Hz}\right), 36.6\left(\Delta v_{1 / 2}=143 \mathrm{~Hz}\right), 29.6\left(\Delta v_{1 / 2}=187 \mathrm{~Hz}\right)$, $27.4\left(\Delta v_{1 / 2}=78 \mathrm{~Hz}\right), 17.5\left(\Delta v_{1 / 2}=29 \mathrm{~Hz}\right)$. Mössbauer Spectroscopy $(95 \mathrm{~K}): \delta=0.9 \mathrm{~mm} / \mathrm{s}, \Delta \mathrm{E}_{\mathrm{Q}}=$ $2.8 \mathrm{~mm} / \mathrm{s}$. Anal Calcd for $\mathrm{C}_{14} \mathrm{H}_{22} \mathrm{Cl}_{2} \mathrm{FeN}_{2}: \mathrm{C}, 48.73 ; \mathrm{H}, 6.43 ; \mathrm{N}, 8.12$. Found: C, 48.81; H, 6.15; $\mathrm{N}: 8.00$. X-Ray data included in X-Ray Crystallographic Analysis section.

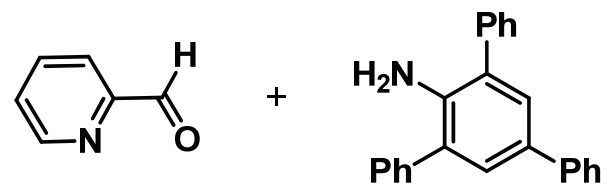

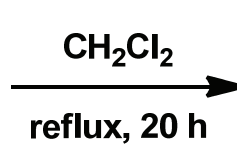

$96 \%$ yield

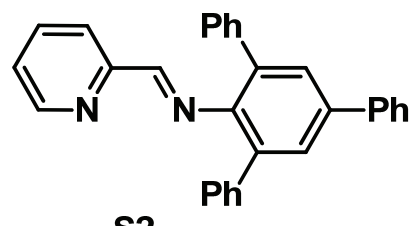

S2

\section{Iminopyridine S2}

In air, to a solution of 2,4,6-triphenylaniline ( $0.964 \mathrm{~g}, 3.00 \mathrm{mmol}, 1.00$ equiv) in $\mathrm{CH}_{2} \mathrm{Cl}_{2}(10 \mathrm{~mL})$ was added 2-pyridinecarboxaldehyde $(0.326 \mathrm{~g}, 0.290 \mathrm{~mL}, 3.05 \mathrm{mmol}, 1.02$ equiv). After heating at reflux for $20 \mathrm{~h}$ with azeotropic removal of water using a Dean-Stark trap, the reaction mixture was concentrated under reduced pressure. The residue was purified by trituration with hexanes and dried in vacuo to give the title compound as a yellow solid (1.18 g, 96\% yield).

Melting Point: $141-144{ }^{\circ} \mathrm{C}$. NMR Spectroscopy: ${ }^{1} \mathrm{H}$ NMR $\left(500 \mathrm{MHz}, \mathrm{CDCl}_{3}, 25{ }^{\circ} \mathrm{C}, \delta\right): 8.52(\mathrm{~d}, J$ $=4.6 \mathrm{~Hz}, 1 \mathrm{H}), 8.08(\mathrm{~s}, 1 \mathrm{H}), 7.89(\mathrm{~d}, J=7.8 \mathrm{~Hz}, 1 \mathrm{H}), 7.67-7.70(\mathrm{~m}, 3 \mathrm{H}), 7.66(\mathrm{~s}, 2 \mathrm{H}), 7.44-7.48$ (m, 7H), 7.30-7.37 (m, 5H), 7.22-7.27 (m, 2H). $\left.{ }^{13} \mathrm{C} \mathrm{NMR} \mathrm{(125} \mathrm{MHz,} \mathrm{CDCl}_{3}, 25{ }^{\circ} \mathrm{C}, \delta\right): 165.4$, 154.3, 149.4, 147.1, 140.6, 139.8, 137.9, 136.5, 134.0, 130.2, 128.9, 128.8, 128.2, 127.4, 127.1, 126.9, 125.1, 121.2. HRMS-ESI $(\mathrm{m} / \mathrm{z})$ : Calcd for $\left[\mathrm{C}_{30} \mathrm{H}_{22} \mathrm{~N}_{2}+\mathrm{Na}\right]$, 433.1675. Found, 433.1657.

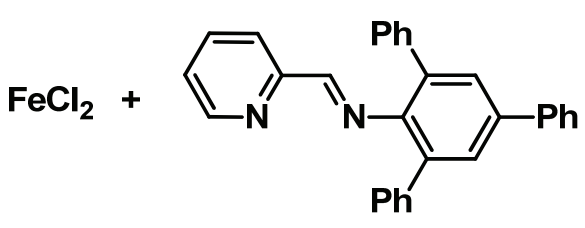

$\mathrm{Ph}$

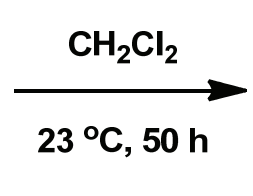

95\% yield

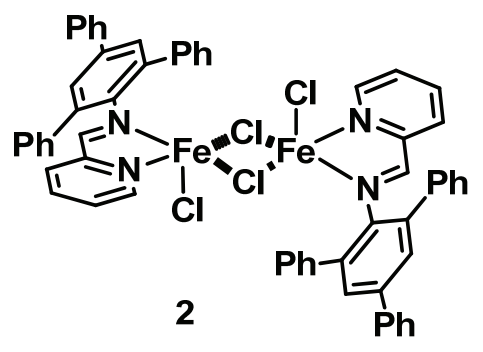

\section{Iron(II) chloride complex 2}

A solution of iminopyridine $\mathbf{S 2}(0.150 \mathrm{~g}, 0.365 \mathrm{mmol}, 1.00$ equiv $)$ in $\mathrm{CH}_{2} \mathrm{Cl}_{2}(5 \mathrm{~mL})$ was added to iron(II) chloride ( $46.3 \mathrm{mg}, 0.365 \mathrm{mmol}, 1.00$ equiv). The reaction mixture was stirred at $23{ }^{\circ} \mathrm{C}$ for $72 \mathrm{~h}$. The reaction mixture was filtered over a celite pad. The residue on the filter cake was eluted with about $5 \mathrm{~mL} \mathrm{CH} \mathrm{Cl}_{2}$ and the combined filtrates were concentrated under reduced pressure. The residue was washed with pentane $(2 \times 7 \mathrm{~mL})$ and dried under reduced pressure to afford the title compound as a green solid $(0.187 \mathrm{~g}, 95 \%$ yield $)$. The title compound was insufficiently soluble in a deuterated solvent, such as $\mathrm{CD}_{2} \mathrm{Cl}_{2}$, to obtain a ${ }^{13} \mathrm{C}$ NMR. X-Ray 
quality crystals were grown from vapor diffusion of diethyl ether into a solution of the title compound in $\mathrm{CH}_{2} \mathrm{Cl}_{2}$ ( 3 to $5 \mathrm{mg}$ dissolved in $1 \mathrm{~mL}$, then filtered over a pad of celite) at $-35{ }^{\circ} \mathrm{C}$ over $48 \mathrm{~h}$.

Magnetic susceptibility (500 MHz, $\left.\mathrm{CD}_{2} \mathrm{Cl}_{2}\right): \mu_{\text {eff }}=5.28 \mu_{\mathrm{B}}(7.4 \mathrm{mg} / \mathrm{mL}) .{ }^{5}$ NMR Spectroscopy: ${ }^{1} \mathrm{H}$ NMR $\left(500 \mathrm{MHz}, \mathrm{CD}_{2} \mathrm{Cl}_{2}, 25{ }^{\circ} \mathrm{C}, \delta\right): 80.28\left(\Delta v_{1 / 2}=187 \mathrm{~Hz}\right), 67.24\left(\Delta v_{1 / 2}=741 \mathrm{~Hz}\right), 57.84$ $\left(\Delta v_{1 / 2}=73 \mathrm{~Hz}\right), 54.71\left(\Delta v_{1 / 2}=68 \mathrm{~Hz}\right), 7.35\left(\Delta v_{1 / 2}=19 \mathrm{~Hz}\right), 6.62\left(\Delta v_{1 / 2}=42 \mathrm{~Hz}\right), 6.51\left(\Delta v_{1 / 2}=28\right.$ $\mathrm{Hz}), 4.65\left(\Delta v_{1 / 2}=54 \mathrm{~Hz}\right), 3.72\left(\Delta v_{1 / 2}=29 \mathrm{~Hz}\right), 1.84\left(\Delta v_{1 / 2}=22 \mathrm{~Hz}\right), 1.28\left(\Delta v_{1 / 2}=50 \mathrm{~Hz}\right), 0.88$ $\left(\Delta v_{1 / 2}=24 \mathrm{~Hz}\right),-13.62\left(\Delta v_{1 / 2}=58 \mathrm{~Hz}\right)$. Mössbauer Spectroscopy $(95 \mathrm{~K}): \delta=1.07 \mathrm{~mm} / \mathrm{s}, \Delta \mathrm{E}_{\mathrm{Q}}=$ $3.35 \mathrm{~mm} / \mathrm{s}$. Anal Calcd for $\mathrm{C}_{60} \mathrm{H}_{44} \mathrm{Cl}_{4} \mathrm{Fe}_{2} \mathrm{~N}_{4}: \mathrm{C}, 67.07 ; \mathrm{H}, 4.13 ; \mathrm{N}, 5.21$. Found: $\mathrm{C}, 66.23 ; \mathrm{H}, 4.22$; $\mathrm{N}: 4.87$. X-Ray data included in X-Ray Crystallographic Analysis section.

${ }^{5}$ Evans, D. F. J. Chem. Soc. 1959, 2003-2005. 


\section{Experimental Procedures for Polymerization}

All polymerization reactions were conducted using inert atmosphere (nitrogen) using a glovebox or conventional Schlenk techniques (for the $10 \mathrm{~g}$ scales).

\section{Example 1: trans-1,4-Polyisoprene (in toluene)}

To a $20 \mathrm{~mL}$ scintillation vial was added iron(II) chloride complex 1 ( $3.2 \mathrm{mg}, 9.3 \mu \mathrm{mol}, 1.0$ equiv) and $2 \mathrm{~mL}$ of toluene, followed by triisobutylaluminum $(5.5 \mathrm{mg}, 28 \mu \mathrm{mol}, 3.0$ equiv) in $1 \mathrm{~mL}$ toluene at $23^{\circ} \mathrm{C}$. The reaction mixture was stirred for $2 \mathrm{~min}$ and trityl tetrakis(pentafluorophenyl)borate $(8.6 \mathrm{mg}, 9.3 \mu \mathrm{mol}, 1.0$ equiv) was added as a solution in $2 \mathrm{~mL}$ toluene at $23^{\circ} \mathrm{C}$. The reaction mixture was stirred for $2 \mathrm{~min}$ and isoprene $(0.681 \mathrm{~g}, 1.00 \mathrm{~mL}, 10.0$ mmol, $1.08 \times 10^{3}$ equiv) was added. The reaction mixture was stirred for 2 hours at $23{ }^{\circ} \mathrm{C}$. The reaction mixture was quenched by opening to air and diluting with DCM from the squirt bottle $(10 \mathrm{~mL})$. The title compound was isolated by precipitation in cold methanol to yield a colorless gum that was dried in vacuo overnight (yield $>99 \% 700 \mathrm{mg}$ ).

NMR Spectroscopy: ${ }^{1} \mathrm{H}$ NMR $\left(500 \mathrm{MHz}, \mathrm{CDCl}_{3}, 23{ }^{\circ} \mathrm{C}, \delta\right.$, relaxation time $\left.10 \mathrm{~s}\right)$ : olefinic $\mathrm{H}$ atoms for 1,4-motif: 5.12 (s, $\left.\Delta v_{1 / 2}=35 \mathrm{~Hz}, 1 \mathrm{H}\right) ; 3,4$-motif: $4.73(\mathrm{~d}, b r, J \sim 20 \mathrm{~Hz}, 1 \mathrm{H}), 4.66$ (d, $b r, J \sim$ $20 \mathrm{~Hz}, 1 \mathrm{H})$; aliphatic $\mathrm{H}$ atoms for 1,4-motif: $2.07(\mathrm{~s}, b, 2 \mathrm{H}), 1.99(\mathrm{~d}, b, J \sim 5 \mathrm{~Hz}, 2 \mathrm{H}), 1.60(\mathrm{~s}$, $3 \mathrm{H})$, ); 3,4-motif : $2.20(\mathrm{~s}, b r, 2 \mathrm{H}), 1.86(\mathrm{~m}, b r, 2 \mathrm{H}), 1.68(\mathrm{~s}, b, 3 \mathrm{H}) .{ }^{13} \mathrm{C} \mathrm{NMR}(125 \mathrm{MHz}$, $\mathrm{CDCl}_{3}, 25{ }^{\circ} \mathrm{C}, \delta$, relaxation time $5 \mathrm{~s}$ ): olefinic $\mathrm{C}$ atoms for trans-1,4-motif: $135.1,124.4 ; 3,4-$ motif: 147.8, 111.4, aliphatic $\mathrm{C}$ atoms for trans-1,4-motif: 39.9, 26.9, $16.2\left(\mathrm{CH}_{3}\right.$-methyl); for cis1,4-motif: $23.7\left(\mathrm{CH}_{3}\right.$-methyl); 3,4-motif: $45.0(\mathrm{~m}), 37.6(\mathrm{~m}), 18.5(\mathrm{~m})$. SEC chromatography (eluent: THF, Polystyrene standards): $M_{w}=125,000 \mathrm{~g} / \mathrm{mol}, D=2.0$. Selectivity: 1,4 / 3,4 $=12: 1$ and trans-1,4 / cis-1,4 > 99:1 (92\% of trans-1,4-polyisoprene in the bulk).

\section{Example 2: trans-1,4-Polyisoprene (higher molar mass in Me-cyclohexane/toluene 5:1)}

To a $20 \mathrm{~mL}$ scintillation vial was added iron(II) chloride complex 1 ( $3.2 \mathrm{mg}, 9.3 \mu \mathrm{mol}, 1.0$ equiv) and $5 \mathrm{~mL}$ of Me-cyclohexane, followed by triisobutylaluminum ( $5.5 \mathrm{mg}, 28 \mu \mathrm{mol}, 3.0$ equiv) in 1 $\mathrm{mL}$ of Me-cyclohexane at $23^{\circ} \mathrm{C}$. The reaction mixture was stirred for $2 \mathrm{~min}$ and trityl tetrakis(pentafluorophenyl)borate ( $8.6 \mathrm{mg}, 9.3 \mu \mathrm{mol}, 1.0$ equiv) was added as a solution in $3 \mathrm{~mL}$ of a 1:1 mixture of Me-cyclohexane and toluene at $23^{\circ} \mathrm{C}$. The reaction mixture was stirred for 2 min and isoprene $\left(1.362 \mathrm{~g}, 2.00 \mathrm{~mL}, 20.0 \mathrm{mmol}, 2.15 \times 10^{3}\right.$ equiv) was added. The reaction mixture was stirred for 4 hours at $23{ }^{\circ} \mathrm{C}$. The reaction mixture was quenched by opening to air and diluting with DCM from the squirt bottle $(10 \mathrm{~mL})$. The title compound was isolated by precipitation in cold methanol to yield a colorless gum that was dried under vacuo overnight (yield $>99 \% 1.4 \mathrm{~g}$ ).

NMR Spectroscopy: ${ }^{1} \mathrm{H}$ NMR $\left(500 \mathrm{MHz}, \mathrm{CDCl}_{3}, 23{ }^{\circ} \mathrm{C}, \delta\right.$, relaxation time $\left.10 \mathrm{~s}\right)$ : olefinic $\mathrm{H}$ atoms for 1,4-motif: $5.12\left(\mathrm{~s}, \Delta v_{1 / 2}=50 \mathrm{~Hz}, 1 \mathrm{H}\right) ; 3,4$-motif: $4.73(\mathrm{~d}, b r, 1 \mathrm{H}), 4.66(\mathrm{~d}, b r, 1 \mathrm{H})$; aliphatic $\mathrm{H}$ atoms for 1,4-motif: 2.07 (s, $b r, 2 \mathrm{H}), 1.99$ (d, $b r, J \sim 5 \mathrm{~Hz}, 2 \mathrm{H}), 1.60$ (s, 3H), ); 3,4-motif : 2.20 
$(\mathrm{s}, b r, 2 \mathrm{H}), 1.86(\mathrm{~m}, b r, 2 \mathrm{H}), 1.68(\mathrm{~s}, b r, 3 \mathrm{H}) .{ }^{13} \mathrm{C} \mathrm{NMR}\left(125 \mathrm{MHz}, \mathrm{CDCl}_{3}, 25{ }^{\circ} \mathrm{C}, \delta\right.$, relaxation time 5s): olefinic $\mathrm{C}$ atoms for trans-1,4-motif: 135.1, 124.4; 3,4-motif: $147.8,111.4$, aliphatic $\mathrm{C}$ atoms for trans-1,4-motif: 39.9, 26.9, $16.2\left(\mathrm{CH}_{3}\right.$-methyl); for cis-1,4-motif: $23.7\left(\mathrm{CH}_{3}\right.$-methyl); 3,4-motif: $45.0(\mathrm{~m}), 37.6(\mathrm{~m}), 18.5(\mathrm{~m})$. SEC chromatography (eluent: THF, Polystyrene standards): $M_{w}=600,000 \mathrm{~g} / \mathrm{mol}, D=2.5$. Selectivity: $1,4 / 3,4>12: 1$ and trans $-1,4 /$ cis- $1,4>$ 99:1 (93\% of trans-1,4-polyisoprene in the bulk).

\section{Example 3: trans-1,4-Polyisoprene (in heptane/toluene 5:1)}

To a $20 \mathrm{~mL}$ scintillation vial was iron(II) chloride complex 1 (3.2 mg, $9.3 \mu \mathrm{mol}, 1.0$ equiv) and 5 $\mathrm{mL}$ of heptane, followed by triisobutylaluminum $(5.5 \mathrm{mg}, 28 \mu \mathrm{mol}, 3.0$ equiv) in $1 \mathrm{~mL}$ of heptane at $23^{\circ} \mathrm{C}$. The reaction mixture was stirred for $2 \mathrm{~min}$ and trityl tetrakis(pentafluorophenyl)borate ( $8.6 \mathrm{mg}, 9.3 \mu \mathrm{mol}, 1.0$ equiv) was added as a solution in $3 \mathrm{~mL}$ of a $1: 1$ mixture of heptane and toluene at $23^{\circ} \mathrm{C}$. The reaction mixture was stirred for $2 \mathrm{~min}$ and isoprene $(1.362 \mathrm{~g}, 2.00 \mathrm{~mL}, 20.0$ mmol, $2.15 \times 10^{3}$ equiv) was added. The reaction mixture was stirred for 4 hours at $23{ }^{\circ} \mathrm{C}$. The reaction mixture was quenched by opening to air and diluting with DCM from the squirt bottle $(10 \mathrm{~mL})$. The title compound was isolated by precipitation in cold methanol to yield a colorless gum that was dried in vacuo overnight (yield $>99 \% 1.4 \mathrm{~g}$ ).

NMR Spectroscopy: ${ }^{1} \mathrm{H}$ NMR $\left(500 \mathrm{MHz}, \mathrm{CDCl}_{3}, 23{ }^{\circ} \mathrm{C}, \delta\right.$, relaxation time $\left.10 \mathrm{~s}\right)$ : olefinic $\mathrm{H}$ atoms for 1,4-motif: $5.12\left(\mathrm{~s}, \Delta v_{1 / 2}=45 \mathrm{~Hz}, 1 \mathrm{H}\right) ; 3,4$-motif: $4.73(\mathrm{~d}, b r, 1 \mathrm{H}), 4.66(\mathrm{~d}, b r, 1 \mathrm{H})$; aliphatic $\mathrm{H}$ atoms for 1,4-motif: $2.07(\mathrm{~s}, b r, 2 \mathrm{H}), 1.99(\mathrm{~d}, b r, J \sim 5 \mathrm{~Hz}, 2 \mathrm{H}), 1.60(\mathrm{~s}, 3 \mathrm{H})$, ); 3,4-motif : 2.20 $(\mathrm{s}, b r, 2 \mathrm{H}), 1.86(\mathrm{~m}, b r, 2 \mathrm{H}), 1.68(\mathrm{~s}, b r, 3 \mathrm{H}) .{ }^{13} \mathrm{C} \mathrm{NMR}\left(125 \mathrm{MHz}, \mathrm{CDCl}_{3}, 25{ }^{\circ} \mathrm{C}, \delta\right.$, relaxation time 5s): olefinic $\mathrm{C}$ atoms for trans-1,4-motif: 135.1, 124.4; 3,4-motif: $147.8,111.4$, aliphatic $\mathrm{C}$ atoms for trans-1,4-motif: 39.9, 26.9, $16.2\left(\mathrm{CH}_{3}\right.$-methyl); for cis-1,4-motif: $23.7\left(\mathrm{CH}_{3}\right.$-methyl); 3,4-motif: $45.0(\mathrm{~m}), 37.6(\mathrm{~m}), 18.5(\mathrm{~m})$. SEC chromatography (eluent: THF, Polystyrene standards): $M_{w}=500,000 \mathrm{~g} / \mathrm{mol}, D=2.6$. Selectivity: $1,4 / 3,4>12: 1$ and trans $-1,4 /$ cis-1,4 $>$ 99:1 (92.5\% of trans-1,4-polyisoprene in the bulk).

\section{Example 4: trans-1,4-Polyisoprene (10g scale)}

To a $500 \mathrm{~mL}$ round-bottom flask was added iron(II) chloride complex 1 (9.6 mg, $28 \mu \mathrm{mol}, 1.0$ equiv) and $10 \mathrm{~mL}$ of toluene, followed by triisobutylaluminum ( $16.5 \mathrm{mg}, 84 \mu \mathrm{mol}, 3.0$ equiv) in 5 $\mathrm{mL}$ toluene at $23^{\circ} \mathrm{C}$. The reaction mixture was stirred for $3 \mathrm{~min}$ and trityl tetrakis(pentafluorophenyl)borate $(25.8 \mathrm{mg}, 28 \mu \mathrm{mol}, 1.0$ equiv) was added as a solution in $5 \mathrm{~mL}$ toluene at $23^{\circ} \mathrm{C}$. The reaction mixture was stirred for $2 \mathrm{~min}$ and $50 \mathrm{~mL}$ of $\mathrm{Me}$-cyclohexane was added to bring the total volume to $70 \mathrm{~mL}$, and then isoprene $(10.0 \mathrm{~g}, 14.7 \mathrm{~mL}, 147 \mathrm{mmol}, 5.25 \times$ $10^{3}$ equiv) was added. The reaction mixture was stirred for 5 hours at $23{ }^{\circ} \mathrm{C}$. The reaction mixture was quenched by opening to air and diluting with DCM from the squirt bottle $(50 \mathrm{~mL})$. The title compound was isolated by precipitation in cold methanol to yield a colorless gum that was dried in vacuo overnight (yield $>99 \% 10.1 \mathrm{~g}$ after drying overnight under vacuum).

NMR Spectroscopy: ${ }^{1} \mathrm{H}$ NMR $\left(500 \mathrm{MHz}, \mathrm{CDCl}_{3}, 23{ }^{\circ} \mathrm{C}, \delta\right.$, relaxation time $\left.10 \mathrm{~s}\right)$ : olefinic protons 
for 1,4-motif: 5.12 (s, $\left.\Delta v_{1 / 2}=45 \mathrm{~Hz}, 1 \mathrm{H}\right)$; 3,4-motif: $4.73(\mathrm{~d}, b r, 1 \mathrm{H}), 4.66(\mathrm{~d}, b, 1 \mathrm{H})$; aliphatic protons for 1,4-motif: $2.07(\mathrm{~s}, b r, 2 \mathrm{H}), 1.99(\mathrm{~d}, b r, J \sim 5 \mathrm{~Hz}, 2 \mathrm{H}), 1.60(\mathrm{~s}, 3 \mathrm{H})$, ); 3,4-motif : 2.20 $(\mathrm{s}, b r, 2 \mathrm{H}), 1.86(\mathrm{~m}, b r, 2 \mathrm{H}), 1.68(\mathrm{~s}, b r, 3 \mathrm{H}) .{ }^{13} \mathrm{C} \mathrm{NMR}\left(125 \mathrm{MHz}, \mathrm{CDCl}_{3}, 25{ }^{\circ} \mathrm{C}, \delta\right.$, relaxation time 5s): olefinic carbons for trans-1,4-motif: 135.1, 124.4; 3,4-motif: 147.8, 111.4, aliphatic carbons for trans-1,4-motif: 39.9, 26.9, 16.2; for cis-1,4-motif: $23.7\left(\mathrm{CH}_{3}\right.$-methyl); 3,4-motif: $45.0(\mathrm{~m}), 37.6(\mathrm{~m}), 18.5(\mathrm{~m})$. SEC chromatography (eluent: THF, Polystyrene standards): $M_{w}=$ $650,000 \mathrm{~g} / \mathrm{mol}, D=3.9$. Selectivity $1,4 / 3,4=12: 1$ and trans $-1,4 /$ cis-1,4 $>99: 1(92.5 \%$ of trans-1,4-polyisoprene in the bulk).

\section{Example 5: cis-1,4-Polyisoprene (in toluene)}

To a $20 \mathrm{~mL}$ scintillation vial was iron(II) chloride complex 2 (5.0 mg, $9.3 \mu \mathrm{mol}, 1.0$ equiv) and 2 $\mathrm{mL}$ of toluene, followed by triethylaluminum $(3.2 \mathrm{mg}, 28 \mu \mathrm{mol}, 3.0$ equiv) in $1 \mathrm{~mL}$ toluene at $23^{\circ} \mathrm{C}$. The reaction mixture was stirred for $2 \mathrm{~min}$ and trityl tetrakis(pentafluorophenyl)borate $(8.6$ $\mathrm{mg}, 9.3 \mu \mathrm{mol}, 1.0$ equiv) was added as a solution in $2 \mathrm{~mL}$ toluene at $23^{\circ} \mathrm{C}$. The reaction mixture was stirred for $5 \mathrm{~min}$ at $-78^{\circ} \mathrm{C}$ and cold isoprene $\left(0.681 \mathrm{~g}, 1.00 \mathrm{~mL}, 10.0 \mathrm{mmol}, 1.08 \times 10^{3}\right.$ equiv) was added. The reaction mixture was stirred for 4 hours at $-78{ }^{\circ} \mathrm{C}$. The reaction mixture was quenched by opening to air and diluting with DCM from the squirt bottle $(10 \mathrm{~mL})$. The title compound was isolated by precipitation in cold methanol to yield a colorless gum that was dried in vacuo overnight (yield $>99 \% 700 \mathrm{mg}$ ).

NMR Spectroscopy: ${ }^{1} \mathrm{H}$ NMR (500 MHz, $\mathrm{CDCl}_{3}, 23{ }^{\circ} \mathrm{C}, \delta$ ): olefinic $\mathrm{H}$ atoms for 1,4-motif: 5.12 (s, $\left.\Delta v_{1 / 2}=50 \mathrm{~Hz}, 1 \mathrm{H}\right)$; 3,4-motif: $4.72(b r, 1 \mathrm{H}), 4.68(b r, 1 \mathrm{H})$; aliphatic $\mathrm{H}$ atoms for 1,4-motif: $2.03(b r, 4 \mathrm{H}), 1.70(\mathrm{~s}, 3 \mathrm{H}) ; 3,4$-motif : $2.22(b r, 1 \mathrm{H}), 1.80(\mathrm{~m}, b r, 2 \mathrm{H}), 1.32(\mathrm{~s}, b r, 3 \mathrm{H}) .{ }^{13} \mathrm{C} \mathrm{NMR}$ $\left(125 \mathrm{MHz}, \mathrm{CDCl}_{3}, 25{ }^{\circ} \mathrm{C}, \delta\right.$ ): olefinic $\mathrm{C}$ atoms for cis-1,4-motif: $135.6(\mathrm{~m}), 134.0(\mathrm{~m}), 126.5(\mathrm{~m})$, $125.3(\mathrm{~m})$; 3,4-motif: 147.7, 111.5, aliphatic $\mathrm{C}$ atoms for cis-1,4-motif: $33.2(\mathrm{~m}), 30.8,28.5(\mathrm{~m})$, 26.1(m), 23.7; 3,4-motif: 45.4 (m), 36.8 (m), 18.5 (m). SEC chromatography (eluent: THF, Polystyrene standards): $M_{w}=140,000 \mathrm{~g} / \mathrm{mol}, D=1.7$. Selectivity $1,4 / 3,4=6: 1$ and cis-1,4 $/$ trans-1,4 > 99:1 (85\% of cis-1,4-polyisoprene in the bulk).

\section{Example 6: cis-1,4-Polyisoprene (in Me-cyclohexane at room temperature)}

To a $20 \mathrm{~mL}$ scintillation vial was added iron(II) chloride complex 2 (5.0 $\mathrm{mg}, 9.3 \mu \mathrm{mol}, 1.0$ equiv) and $2 \mathrm{~mL}$ of Me-cyclohexane, followed by triethylaluminum (3.2 mg, $28 \mu \mathrm{mol}, 3.0$ equiv) in 1 $\mathrm{mL}$ Me-cyclohexane at $23^{\circ} \mathrm{C}$. The reaction mixture was stirred for $2 \mathrm{~min}$ and trityl tetrakis(pentafluorophenyl)borate $(8.6 \mathrm{mg}, 9.3 \mu \mathrm{mol}, 1.0$ equiv) was added as a dispersion in 2 $\mathrm{mL}$ Me-cyclohexane at $23^{\circ} \mathrm{C}$. The reaction mixture was stirred for $2 \mathrm{~min}$ and isoprene $(0.681 \mathrm{~g}$, $1.00 \mathrm{~mL}, 10.0 \mathrm{mmol}, 1.08 \times 10^{3}$ equiv) was added. The reaction mixture was stirred for 2 hours at $23{ }^{\circ} \mathrm{C}$. The reaction mixture was quenched by opening to air and diluting with DCM from the squirt bottle $(10 \mathrm{~mL})$. The title compound was isolated by precipitation in cold methanol to yield a colorless gum that was dried in vacuo overnight (yield $>99 \% 700 \mathrm{mg}$ ).

NMR Spectroscopy: ${ }^{1} \mathrm{H}$ NMR (500 MHz, $\mathrm{CDCl}_{3}, 23{ }^{\circ} \mathrm{C}, \delta$ ): olefinic $\mathrm{H}$ atoms for 1,4-motif: 5.12 
(s, $\left.\Delta v_{1 / 2}=40 \mathrm{~Hz}, 1 \mathrm{H}\right) ; 3,4-$ motif: $4.72(\mathrm{~d}, 1 \mathrm{H}, b r), 4.68(\mathrm{~d}, 1 \mathrm{H}, b r)$; aliphatic $\mathrm{H}$ atoms for 1,4motif: $2.03(4 \mathrm{H}, b r), 1.70(3 \mathrm{H}, b r)$; 3,4-motif : $2.22(1 \mathrm{H}, b r), 1.80(\mathrm{~m}, b r, 2 \mathrm{H}), 1.32(\mathrm{~s}, b r, 3 \mathrm{H})$.

${ }^{13} \mathrm{C}$ NMR (125 MHz, $\left.\mathrm{CDCl}_{3}, 25{ }^{\circ} \mathrm{C}, \delta\right)$ : olefinic $\mathrm{C}$ atoms for cis-1,4-motif: $135.6(\mathrm{~m}), 134.0(\mathrm{~m})$, 126.5 (m), 125.3 (m); 3,4-motif: 147.7, 111.5, aliphatic C atoms for cis-1,4-motif: $33.2(\mathrm{~m}), 30.8$, 28.5(m), 26.1(m), 23.7; 3,4-motif: 45.4 (m), 36.8 (m), 18.5 (m). SEC chromatography (eluent: THF, Polystyrene standards): $M_{w}=100,000 \mathrm{~g} / \mathrm{mol}, D=2.3$. Selectivity $1,4 / 3,4=3: 1$ and cis $-1,4$ / trans-1,4 > 99:1 (75\% of cis-1,4-polyisoprene in the bulk).

\section{Example 7: cis-1,4-Polyisoprene (in toluene at room temperature)}

To a $20 \mathrm{~mL}$ scintillation vial was iron(II) chloride complex 2 (5.0 $\mathrm{mg}, 9.3 \mu \mathrm{mol}, 1.0$ equiv) and 2 $\mathrm{mL}$ of toluene, followed by triethylaluminum $(3.2 \mathrm{mg}, 28 \mu \mathrm{mol}, 3.0$ equiv) in $1 \mathrm{~mL}$ toluene at $23^{\circ} \mathrm{C}$. The reaction mixture was stirred for $2 \mathrm{~min}$ and trityl tetrakis(pentafluorophenyl)borate $(8.6$ $\mathrm{mg}, 9.3 \mu \mathrm{mol}, 1.0$ equiv) was added as a solution in $2 \mathrm{~mL}$ toluene at $23^{\circ} \mathrm{C}$. The reaction mixture was stirred for $2 \mathrm{~min}$ and isoprene $\left(0.681 \mathrm{~g}, 1.00 \mathrm{~mL}, 10.0 \mathrm{mmol}, 1.08 \times 10^{3}\right.$ equiv) was added. The reaction mixture was stirred for 1 hour at $23{ }^{\circ} \mathrm{C}$. The reaction mixture was quenched by opening to air and diluting with DCM from the squirt bottle $(10 \mathrm{~mL})$. The title compound was isolated by precipitation in cold methanol to yield a colorless gum that was dried in vacuo overnight (yield $>99 \% 700 \mathrm{mg}$ ).

NMR Spectroscopy: ${ }^{1} \mathrm{H}$ NMR $\left(500 \mathrm{MHz}, \mathrm{CDCl}_{3}, 23{ }^{\circ} \mathrm{C}\right.$, $\delta$ ): olefinic $\mathrm{H}$ atoms for 1,4-motif: 5.12 (s, $\left.\Delta v_{1 / 2}=40 \mathrm{~Hz}, 1 \mathrm{H}\right)$; 3,4-motif: $4.72(b r, 1 \mathrm{H}), 4.68(b r, 1 \mathrm{H})$; aliphatic $\mathrm{H}$ atoms for 1,4-motif: $2.03(b r, 4 \mathrm{H}), 1.70(\mathrm{~s}, b r 3 \mathrm{H}) ; 3,4$-motif : $2.22(b r, 1 \mathrm{H}), 1.80(\mathrm{~m}, b r, 2 \mathrm{H}), 1.32(\mathrm{~s}, b r, 3 \mathrm{H}) .{ }^{13} \mathrm{C}$ NMR (125 MHz, $\left.\mathrm{CDCl}_{3}, 25{ }^{\circ} \mathrm{C}, \delta\right)$ : olefinic $\mathrm{C}$ atoms for cis-1,4-motif: $135.6(\mathrm{~m}), 134.0(\mathrm{~m})$, 126.5 (m), 125.3 (m); 3,4-motif: 147.7, 111.5, aliphatic $C$ atoms for $c i s-1,4$-motif: $33.2(\mathrm{~m}), 30.8$, 28.5(m), 26.1(m), 23.7; 3,4-motif: $45.4(\mathrm{~m}), 36.8$ (m), 18.5 (m). SEC chromatography (eluent: THF, Polystyrene standards): $M_{w}=150,000 \mathrm{~g} / \mathrm{mol}, D=1.9$. Selectivity $1,4 / 3,4=2: 1$ and cis $-1,4$ / trans-1,4 > 99:1 (66\% of cis-1,4-polyisoprene in the bulk).

\section{Example 8: cis-1,4-Polyisoprene (10g scale)}

To a $500 \mathrm{~mL}$ round-bottom flask was added iron(II) chloride $2(15.0 \mathrm{mg}, 28 \mu \mathrm{mol}, 1.0$ equiv) and $10 \mathrm{~mL}$ of toluene, followed by triethylaluminum $(9.6 \mathrm{mg}, 84 \mu \mathrm{mol}, 3.0$ equiv) in $5 \mathrm{~mL}$ toluene at $23^{\circ} \mathrm{C}$. The reaction mixture was stirred for $5 \mathrm{~min}$ and trityl tetrakis(pentafluorophenyl)borate ( $25.8 \mathrm{mg}, 28 \mu \mathrm{mol}, 1.0$ equiv) was added as a solution in $5 \mathrm{~mL}$ toluene at $23^{\circ} \mathrm{C}$. The reaction mixture was mixed for $5 \mathrm{~min}$ at $-78^{\circ} \mathrm{C}$ and $50 \mathrm{~mL}$ of $\mathrm{Me}$-cyclohexane was added to bring the total volume to $70 \mathrm{~mL}$, and then isoprene $\left(10.0 \mathrm{~g}, 14.7 \mathrm{~mL}, 147 \mathrm{mmol}, 5.25 \times 10^{3}\right.$ equiv) was added at $-78^{\circ} \mathrm{C}$. The reaction mixture was stirred for 5 hours at $-78{ }^{\circ} \mathrm{C}$. The reaction mixture was quenched by opening to air and diluting with DCM from the squirt bottle $(50 \mathrm{~mL})$. The title compound was isolated by precipitation in cold methanol to yield a colorless gum that was dried in vacuo overnight (yield $>99 \% 10.1 \mathrm{~g}$ after drying overnight under vacuum).

NMR Spectroscopy: ${ }^{1} \mathrm{H}$ NMR (500 MHz, $\mathrm{CDCl}_{3}, 23{ }^{\circ} \mathrm{C}, \delta$ ): olefinic $\mathrm{H}$ atoms for 1,4-motif: 5.12 
(s, $\left.\Delta v_{1 / 2}=50 \mathrm{~Hz}, 1 \mathrm{H}\right) ; 3,4-$ motif: $4.72(b r, 1 \mathrm{H}), 4.68(b r, 1 \mathrm{H})$; aliphatic $\mathrm{H}$ atoms for 1,4-motif: $2.03(b r, 4 \mathrm{H}), 1.70(\mathrm{~s}, 3 \mathrm{H}) ; 3,4$-motif : $2.22(b r, 1 \mathrm{H}), 1.80(\mathrm{~m}, b r, 2 \mathrm{H}), 1.32(\mathrm{~s}, b r, 3 \mathrm{H}) .{ }^{13} \mathrm{C} \mathrm{NMR}$ $\left(125 \mathrm{MHz}, \mathrm{CDCl}_{3}, 25{ }^{\circ} \mathrm{C}, \delta\right.$ ): olefinic $\mathrm{C}$ atoms for cis-1,4-motif: $135.6(\mathrm{~m}), 134.0(\mathrm{~m}), 126.5(\mathrm{~m})$, $125.3(\mathrm{~m})$; 3,4-motif: 147.7, 111.5, aliphatic $\mathrm{C}$ atoms for cis-1,4-motif: $33.2(\mathrm{~m}), 30.8,28.5(\mathrm{~m})$, 26.1(m), 23.7; 3,4-motif: 45.4 (m), 36.8 (m), 18.5 (m). SEC chromatography (eluent: THF, Polystyrene standards): $M_{w}=800,000 \mathrm{~g} / \mathrm{mol}, D=3.5$. Selectivity $1,4 / 3,4=5: 1$ and cis-1,4 / trans-1,4 > 99:1 (83\% of cis-1,4-polyisoprene in the bulk).

\section{Example 9: trans-1,4-Poly- $\beta$-myrcene}

To a $20 \mathrm{~mL}$ scintillation vial was added iron(II) chloride complex 1 ( $3.2 \mathrm{mg}, 9.3 \mu \mathrm{mol}, 1.0$ equiv) and $2 \mathrm{~mL}$ of toluene, followed by triisobutylaluminum $(9.2 \mathrm{mg}, 46 \mu \mathrm{mol}, 5.0$ equiv) in $1 \mathrm{~mL}$ toluene at $23^{\circ} \mathrm{C}$. The reaction mixture was stirred for $2 \mathrm{~min}$ and trityl tetrakis(pentafluorophenyl)borate $(8.6 \mathrm{mg}, 9.3 \mu \mathrm{mol}, 1.0$ equiv) was added as a solution in $2 \mathrm{~mL}$ toluene at $23^{\circ} \mathrm{C}$. The reaction mixture was stirred for $2 \mathrm{~min}$ and $\beta$-myrcene $(2.384 \mathrm{~g}, 3.00 \mathrm{~mL}$, $17.5 \mathrm{mmol}, 1.89 \times 10^{3}$ equiv) was added. The reaction mixture was stirred for 2 hours at $23{ }^{\circ} \mathrm{C}$. The reaction mixture was quenched by opening to air and diluting with DCM from the squirt bottle $(10 \mathrm{~mL})$. The title compound was isolated by precipitation in cold methanol to yield a colorless gum that was dried in vacuo overnight (yield 91\% $2.17 \mathrm{~g}$ ).

NMR Spectroscopy: ${ }^{1} \mathrm{H}$ NMR $\left(500 \mathrm{MHz}, \mathrm{CDCl}_{3}, 23{ }^{\circ} \mathrm{C}, \delta\right.$, relaxation time $\left.10 \mathrm{~s}\right)$ : olefinic $\mathrm{H}$ atoms for 1,4-motif: 5.13 (s, $\left.\Delta v_{1 / 2}=35 \mathrm{~Hz}, 2 \mathrm{H}\right)$; 3,4-motif: $4.76(\mathrm{~d}, b r, J \sim 20 \mathrm{~Hz}, 1 \mathrm{H}), 4.72(\mathrm{~d}, b r, J \sim$ $20 \mathrm{~Hz}, 1 \mathrm{H}$ ); aliphatic $\mathrm{H}$ atoms for 1,4-motif: 2.03 (t, $b r, 2 \mathrm{H}, J \sim 16 \mathrm{~Hz}), 2.08(\mathrm{~s}, b r, 2 \mathrm{H}), 1.99$ (s, $b, 2 \mathrm{H}), 1.68(\mathrm{~s}, 3 \mathrm{H}), 1.60$ (s, 3H); 3,4-motif : non-detectable. ${ }^{13} \mathrm{C} \mathrm{NMR}\left(125 \mathrm{MHz}, \mathrm{CDCl}_{3}, 25{ }^{\circ} \mathrm{C}\right.$, $\delta$, relaxation time $5 \mathrm{~s}$ ): olefinic $\mathrm{C}$ atoms for trans-1,4-motif: 139.2, 131.6, 125.0, 124.6; 3,4-motif: non-detectable, aliphatic $\mathrm{C}$ atoms for trans-1,4-motif: 37.5, 30.6, 27.3, 27.1, 25.9,17.8 $\left(\mathrm{CH}_{3-}\right.$ methyl); for cis-1,4-motif: non-detectable; 3,4-motif: non-detectable. SEC chromatography (eluent: THF, Polystyrene standards): $M_{w}=250,000 \mathrm{~g} / \mathrm{mol}, D=2.1$. Selectivity: 1,4 / 3,4 $=12: 1$ and trans-1,4/cis-1,4 > 20:1.

\section{Example 10: cis-1,4-Poly- $\beta$-myrcene}

To a $20 \mathrm{~mL}$ scintillation vial was added iron(II) chloride complex 2 (5.0 $\mathrm{mg}, 9.3 \mu \mathrm{mol}, 1.0$ equiv) and $2 \mathrm{~mL}$ of toluene, followed by triethylaluminum $(5.3 \mathrm{mg}, 46 \mu \mathrm{mol}, 5.0$ equiv) in $1 \mathrm{~mL}$ toluene at $23^{\circ} \mathrm{C}$. The reaction mixture was stirred for $2 \mathrm{~min}$ and trityl tetrakis(pentafluorophenyl)borate ( $8.6 \mathrm{mg}, 9.3 \mu \mathrm{mol}, 1.0$ equiv) was added as a dispersion in $2 \mathrm{~mL}$ toluene at $23^{\circ} \mathrm{C}$. The reaction mixture was stirred for $2 \mathrm{~min}$ and $\beta$-myrcene $\left(2.384 \mathrm{~g}, 3.00 \mathrm{~mL}, 17.5 \mathrm{mmol}, 1.89 \times 10^{3}\right.$ equiv) was added. The reaction mixture was stirred for 2 hours at $23{ }^{\circ} \mathrm{C}$. The reaction mixture was quenched by opening to air and diluting with DCM from the squirt bottle $(10 \mathrm{~mL})$. The title compound was isolated by precipitation in cold methanol to yield a colorless gum that was dried in vacuo overnight (yield $>99 \% 2.07 \mathrm{~g}$ ).

NMR Spectroscopy: ${ }^{1} \mathrm{H}$ NMR (500 MHz, $\mathrm{CDCl}_{3}, 23{ }^{\circ} \mathrm{C}, \delta$ ): olefinic $\mathrm{H}$ atoms for 1,4-motif: 5.11 
(s, $\left.\Delta v_{1 / 2}=40 \mathrm{~Hz}, 2 \mathrm{H}\right) ; 3,4$-motif: $4.76(\mathrm{~m}, b r, 2 \mathrm{H})$; aliphatic $\mathrm{H}$ atoms for 1,4-motif: 2.04 (t, $b r$, 2H, $J \sim 15 \mathrm{~Hz}$ ), 2.06 (s, $b r, 2 \mathrm{H}), 2.00$ (s, $b, 2 \mathrm{H}), 1.67$ (s, 3H), 1.59 (s, 3H); 3,4-motif : 2.17 (br, $1 \mathrm{H}), 1.85(\mathrm{~m}, b r, 2 \mathrm{H}), 1.37(\mathrm{~s}, b r, 3 \mathrm{H}) .{ }^{13} \mathrm{C} \mathrm{NMR}\left(125 \mathrm{MHz}, \mathrm{CDCl}_{3}, 25{ }^{\circ} \mathrm{C}, \delta\right)$ : olefinic $\mathrm{C}$ atoms for cis-1,4-motif: $139.5(\mathrm{~m}), 131.4(\mathrm{~m}), 124.7(\mathrm{~m})$; 3,4-motif: 152.2, 109.1, aliphatic $\mathrm{C}$ atoms for cis-1,4-motif: 37.3, 37.0, 29.7(6), 28.5(m), 27.2, 25.8, 17.8; 3,4-motif: 44.8, 33.4 (m), 26.6. SEC chromatography (eluent: THF, Polystyrene standards): $M_{w}=230,000 \mathrm{~g} / \mathrm{mol}, D=2.2$. Selectivity $1,4 / 3,4=4: 1$ and cis-1,4/trans-1,4 > 20:1.

\section{Example 11: trans-1,4-Poly- $\beta$-farnesene}

To a $20 \mathrm{~mL}$ scintillation vial was added iron(II) chloride complex 1 ( $3.2 \mathrm{mg}, 9.3 \mu \mathrm{mol}, 1.0$ equiv) and $2 \mathrm{~mL}$ of toluene, followed by triisobutylaluminum ( $28 \mathrm{mg}, 140 \mu \mathrm{mol}, 15$ equiv, to activate and dry the commercially available mixture of farnesene isomers) in $1 \mathrm{~mL}$ toluene at $23^{\circ} \mathrm{C}$. The reaction mixture was stirred for $2 \mathrm{~min}$ and trityl tetrakis(pentafluorophenyl)borate $(8.6 \mathrm{mg}, 9.3$ $\mu$ mol, 1.0 equiv) was added as a solution in $2 \mathrm{~mL}$ toluene at $23^{\circ} \mathrm{C}$. The reaction mixture was stirred for $2 \mathrm{~min}$ and a mixture of farnesene isomers $\left(3.58 \mathrm{~g}, 4.50 \mathrm{~mL}, 17.5 \mathrm{mmol}, 1.89 \times 10^{3}\right.$ equiv) containing an extra quantity of triisobutylaluminum ( $28 \mathrm{mg}, 140 \mu \mathrm{mol}, 15$ equiv, to dry the commercially available mixture of farnesene isomers), was added. The reaction mixture was stirred for 2 hours at $23{ }^{\circ} \mathrm{C}$. The reaction mixture was quenched by opening to air and diluting with DCM from the squirt bottle $(10 \mathrm{~mL})$. The title compound was isolated by precipitation in cold methanol to yield a white gum (yield $61 \%, 2.2 \mathrm{~g}$ after drying overnight under vacuum, residues of $\alpha$-farnesene are still present in the bulk, the yield is slightly overestimated).

NMR Spectroscopy: ${ }^{1} \mathrm{H}$ NMR $\left(500 \mathrm{MHz}, \mathrm{CDCl}_{3}, 23{ }^{\circ} \mathrm{C}, \delta\right.$, relaxation time $\left.10 \mathrm{~s}\right)$ : olefinic $\mathrm{H}$ atoms for 1,4-motif: 5.14 (s, $\left.\Delta v_{1 / 2}=45 \mathrm{~Hz}, 3 \mathrm{H}\right)$; 3,4-motif: $4.78(\mathrm{~d}, b r, J \sim 10 \mathrm{~Hz}, 1 \mathrm{H}), 4.66$ (d, $b r, J \sim$ $10 \mathrm{~Hz}, 1 \mathrm{H})$; aliphatic $\mathrm{H}$ atoms for 1,4-motif: $2.03(\mathrm{~m}, b, 2 \mathrm{H}), 1.99(\mathrm{~m}, b, 2 \mathrm{H}), 1.67$ and 1.60 (s, $\mathrm{br}, 9 \mathrm{H})$; 3,4-motif : non-detectable. ${ }^{13} \mathrm{C}$ NMR $\left(125 \mathrm{MHz}, \mathrm{CDCl}_{3}, 25{ }^{\circ} \mathrm{C}, \delta\right.$, relaxation time $\left.5 \mathrm{~s}\right)$ : olefinic $\mathrm{C}$ atoms for trans-1,4-motif: 139.2, 135.3, 131.5, 125.3, 124.9, 124.5; 3,4-motif: 109.9, aliphatic $\mathrm{C}$ atoms for trans-1,4-motif: 39.9, 37.6, 32.1, 30.9, 30.6, 27 (m), 25.8, 23.6, 22.6, 17.6, $16.2\left(\mathrm{CH}_{3}\right.$-methyl); for cis-1,4-motif: $22.6\left(\mathrm{CH}_{3}\right.$-methyl); 3,4-motif: 22.5 (m). SEC chromatography (eluent: THF, Polystyrene standards): $M_{w}=110,000 \mathrm{~g} / \mathrm{mol}, D=1.5$. Selectivity: $1,4 / 3,4=11: 1$ and trans-1,4/ cis-1,4 > 20:1.

\section{Example 12: cis-1,4-Poly- $\beta$-farnesene}

To a $20 \mathrm{~mL}$ scintillation vial was iron(II) chloride complex 2 (5.0 $\mathrm{mg}, 9.3 \mu \mathrm{mol}, 1.0$ equiv) and 2 $\mathrm{mL}$ of toluene, followed by triethylaluminum $(16 \mathrm{mg}, 140 \mu \mathrm{mol}, 15$ equiv, to activate and dry the commercially available mixture of farnesene isomers) in $1 \mathrm{~mL}$ toluene at $23^{\circ} \mathrm{C}$. The reaction mixture was stirred for $2 \mathrm{~min}$ and trityl tetrakis(pentafluorophenyl)borate $(8.6 \mathrm{mg}, 9.3 \mu \mathrm{mol}, 1.0$ equiv) was added as a dispersion in $2 \mathrm{~mL}$ tolune at $23^{\circ} \mathrm{C}$. The reaction mixture was mixed for 2 min and a mixture of farnesene isomers $\left(3.58 \mathrm{~g}, 4.50 \mathrm{~mL}, 17.5 \mathrm{mmol}, 1.89 \times 10^{3}\right.$ equiv) containing an extra quantity of triethylaluminum $(16 \mathrm{mg}, 140 \mu \mathrm{mol}, 15$ equiv, to dry the 
commercially available mixture of farnesene isomers), was added at $23^{\circ} \mathrm{C}$. The reaction mixture was stirred for 5 hours at $-78{ }^{\circ} \mathrm{C}$. The reaction mixture was quenched by opening to air and diluting with DCM from the squirt bottle $(10 \mathrm{~mL})$. The title compound was isolated by precipitation in cold methanol to yield a white gum (yield 53\%, $1.9 \mathrm{~g}$ after drying overnight under vacuum, residues of $\alpha$-farnesene are still present in the bulk, the yield is slightly overestimated).

NMR Spectroscopy: ${ }^{1} \mathrm{H}$ NMR (500 MHz, $\mathrm{CDCl}_{3}, 23{ }^{\circ} \mathrm{C}, \delta$ ): olefinic $\mathrm{H}$ atoms for 1,4-motif: 5.14 (s, $\left.\Delta v_{1 / 2}=40 \mathrm{~Hz}, 3 \mathrm{H}\right)$; 3,4-motif: $4.78(\mathrm{~d}, b r, J \sim 10 \mathrm{~Hz}, 1 \mathrm{H}), 4.66(\mathrm{~d}, b r, J \sim 10 \mathrm{~Hz}, 1 \mathrm{H})$; aliphatic $\mathrm{H}$ atoms for 1,4-motif: $2.03(\mathrm{~m}, b, 2 \mathrm{H}), 1.99(\mathrm{~m}, b, 2 \mathrm{H}), 1.67$ and $1.60(\mathrm{~s}, b r, 9 \mathrm{H})$; 3,4motif : $2.15(b r, 1 \mathrm{H}), \sim 1.9(\mathrm{~m}, b r, 2 \mathrm{H}), 1.36(\mathrm{~s}, b r, 3 \mathrm{H}) .{ }^{13} \mathrm{C} \mathrm{NMR}\left(125 \mathrm{MHz}, \mathrm{CDCl}_{3}, 25{ }^{\circ} \mathrm{C}, \delta\right)$ : olefinic $\mathrm{C}$ atoms for cis-1,4-motif: 139.5, 135.0, 131.3, 125.1, 124.4; 3,4-motif: 152.2, 146.1, 109.9, 109.1, 107.2, aliphatic $C$ atoms for cis-1,4-motif: 37.3, 32.5, 29.7, 27 (m), 23.6, 22.6, 17.8, 16.2; 3,4-motif: 22.5. SEC chromatography (eluent: THF, Polystyrene standards): $M_{w}=100,000$ $\mathrm{g} / \mathrm{mol}, D=1.4$. Selectivity $1,4 / 3,4=4: 1$ and cis-1,4 $/$ trans- $1,4>20: 1$.

\section{Control Experiments}

Control experiments have been run and no noticeable polymerization was obtained when either of the components was left out. Trialkylaluminum derivatives alone or in combination with either of the two other ingredients provided less than $5 \%$ conversion of the isoprene into various isomers and cyclization products which is characteristic of cationic processes that are usually difficult to control especially at ambient temperature with isoprene (or other dienes) as monomers. $\left[\mathrm{Ph}_{3} \mathrm{C}^{+}\right][$ $\mathrm{BArF}_{20}$ ] alone or in combination with either of the two other ingredients did not yield polydiene. Without iron chloride, no polymer was generated either. 


\section{References and Notes}

The determination of NMR chemical shifts was accomplished using the following references, matching with values displayed in their Supplementary Information respective sections: ${ }^{6-11}$

W. Gao, D. Cui J. Am. Chem. Soc. 2008, 130, 4984-4991

D. Cui et al. Organometallics 2010, 29, 2186-2193

K. Lv, D. Cui Organometallics 2010, 29, 2987-2993

S. Zhang, Z. Hou, X. Li et al. Organometallics 2011, 30, 160-170

S. V. Kostjuk et al Macromolecules 2011, 44, 1372-1384

Peruch et al. J. Polym. Sci. Part A: Polym. Chem. 2011, 49, 4948-4954

A review concerning polyisoprenoids has been published: ${ }^{12}$

Peruch et al. Polym. Int. 2012, 61, 149-156

The use of $\mathrm{AlEt}_{3}$ in the octyl-iminopyridine ferrous chloride catalyzed polymerization of isoprene, stereoselective for trans-1,4-polyisoprene, resulted in a slightly less selective polymerization $\left(91-92 \%\right.$ trans-1,4-polyisoprene at $\left.23^{\circ} \mathrm{C}\right)$.

The use of $\mathrm{AliBu}_{3}$ in the supermesityl-iminopyridine ferrous chloride catalyzed polymerization of isoprene, stereoselective for cis-1,4-polyisoprene, resulted in a slightly less selective polymerization $\left(55-60 \%\right.$ cis-1,4-polyisoprene at $\left.23^{\circ} \mathrm{C}\right)$.

The ferrous chloride complexes are relatively bench-stable, they slowly oxidize to $\mathrm{Fe}(\mathrm{III})$, after several days spent on the bench: their bright color (orange for $\mathbf{1}$ or green for $\mathbf{2}$ ) turns to rust.

Warning, the manipulation of trialkylaluminum reagents is hazardous. They are extremely pyrophoric reagents that should be handled with care. If a fire is ignited, two ways to extinguish it are reliable: a thick fire-proof safety blanket and either a powder or $\mathrm{CO}_{2}$ extinguisher. 


\section{Equations used to determine selectivities}

\section{Polyisoprene}

$$
\begin{gathered}
{[\% 1,4-\text { motif }]=\frac{\mathrm{A}(\sim \mathrm{CH}=\mathrm{CMe}-1,4-\text { motif })}{\mathrm{A}(\sim \mathrm{CH}=\mathrm{CMe}-1,4-\text { motif })+\frac{\mathrm{A}\left(\mathrm{CH}_{2}=\mathrm{CMe}-3,4-\text { motif }\right)}{2}}} \\
{[\% 1,4-\text { motif }]=\frac{\mathrm{A}(5.12 \mathrm{ppm})}{\mathrm{A}(5.12 \mathrm{ppm})+\frac{\mathrm{A}(4.5-4.9 \mathrm{ppm})}{2}}} \\
{[\% \text { trans }-1,4-\text { motif }]=\frac{\mathrm{A}\left(\mathrm{CH}_{3}-\text { trans }-1,4-\text { motif }\right)}{\mathrm{A}\left(\mathrm{CH}_{3}-\text { trans }-1,4-\text { motif }\right)+\mathrm{A}\left(\mathrm{CH}_{3}-\text { cis }-1,4-\text { motif }\right)}} \\
{[\% \text { trans }-1,4-\text { motif }]=\frac{\mathrm{A}(16.2 \mathrm{ppm})}{\mathrm{A}(16.2 \mathrm{ppm})+\mathrm{A}(23.7 \mathrm{ppm})}} \\
{[\% \text { cis }-1,4-\text { motif }]=\frac{\mathrm{A}\left(\mathrm{CH} \mathrm{H}_{3}-\text { cis }-1,4-\text { motif }\right)}{\mathrm{A}\left(\mathrm{CH} \mathrm{H}_{3}-\text { cis }-1,4-\text { motif }\right)+\mathrm{A}\left(\mathrm{CH} \mathrm{H}_{3}-\text { trans }-1,4-\text { motif }\right)}} \\
{[\% \text { cis }-1,4-\text { motif }]=\frac{\mathrm{A}(23.7 \mathrm{ppm})}{\mathrm{A}(23.7 \mathrm{ppm})+\mathrm{A}(16.2 \mathrm{ppm})}}
\end{gathered}
$$

\section{Polymyrcene}

$$
\begin{gathered}
{[\% 1,4-\text { motif }]=\frac{\frac{\mathrm{A}(\sim \mathrm{CH}=\mathrm{CMe})}{2}}{\frac{\mathrm{A}(\sim \mathrm{CH}=\mathrm{CMe})}{2}+\frac{\mathrm{A}\left(\mathrm{CH} H_{2}=\mathrm{CMe}-3,4-\text { motif }\right)}{2}}} \\
{[\% 1,4-\text { motif }]=\frac{\mathrm{A}(5.12 \mathrm{ppm})}{\mathrm{A}(5.12 \mathrm{ppm})+\mathrm{A}(4.76 \mathrm{ppm})}} \\
{[\% \text { trans }-1,4-\text { motif }]=\frac{\mathrm{A}\left(\sim \mathrm{C} \mathrm{H}_{2}-\text { trans }-1,4-\text { motif }\right)}{\mathrm{A}\left(\sim C \mathrm{H}_{2}-\text { trans }-1,4-\text { motif }\right)+\mathrm{A}\left(\sim \mathrm{CH} \mathrm{H}_{2}-\text { cis }-1,4-\text { motif }\right)}} \\
{[\% \text { trans }-1,4-\text { motif }]=\frac{\mathrm{A}(30.6 \mathrm{ppm})}{\mathrm{A}(30.6 \mathrm{ppm})+\mathrm{A}(29.6 \mathrm{ppm})}}
\end{gathered}
$$




$$
\begin{gathered}
{[\% \text { cis }-1,4-\text { motif }]=\frac{\mathrm{A}\left(\sim \mathrm{CH}_{2}-\text { cis }-1,4-\text { motif }\right)}{\mathrm{A}\left(\sim C \mathrm{H}_{2}-\text { cis }-1,4-\text { motif }\right)+\mathrm{A}\left(\sim C \mathrm{H}_{2}-\text { trans }-1,4-\text { motif }\right)}} \\
{[\% \text { cis }-1,4-\text { motif }]=\frac{\mathrm{A}(29.6 \mathrm{ppm})}{\mathrm{A}(29.6 \mathrm{ppm})+\mathrm{A}(30.6 \mathrm{ppm})}}
\end{gathered}
$$

\section{Polyfarnesene}

$$
\begin{gathered}
{[\% 1,4-\text { motif }]=\frac{\frac{\mathrm{A}(\sim \mathrm{CH}=\mathrm{CMe})}{3}}{\frac{\mathrm{A}(\sim \mathrm{CH}=\mathrm{CMe})}{3}+\frac{\mathrm{A}\left(\mathrm{CH} H_{2}=\mathrm{CMe}-3,4-\text { motif }\right)}{2}}} \\
{[\% 1,4-\text { motif }]=\frac{\frac{\mathrm{A}(5.13 \mathrm{ppm})}{3}}{\frac{\mathrm{A}(5.13 \mathrm{ppm})}{3}+\frac{\mathrm{A}(4.6-4.8 \mathrm{ppm})}{2}}} \\
{[\% \text { trans }-1,4-\text { motif }]=\frac{\mathrm{A}\left(\sim C \mathrm{H}_{2}-\text { trans }-1,4-\text { motif }\right)}{\mathrm{A}\left(\sim C \mathrm{H}_{2}-\text { trans }-1,4-\text { motif }\right)+\mathrm{A}\left(\sim C \mathrm{H}_{2}-\text { cis }-1,4-\text { motif }\right)}} \\
{[\% \text { trans }-1,4-\text { motif }]=\frac{\mathrm{A}(32.1 \mathrm{ppm})}{\mathrm{A}(32.1 \mathrm{ppm})+\mathrm{A}(29.7 \mathrm{ppm})}} \\
{[\% \text { cis }-1,4-\text { motif }]=\frac{\mathrm{A}\left(\sim C \mathrm{H}_{2}-\text { cis }-1,4-\text { motif }\right)}{\mathrm{A}\left(\sim C \mathrm{H}_{2}-\text { cis }-1,4-\text { motif }\right)+\mathrm{A}\left(\sim C \mathrm{H}_{2}-\text { trans }-1,4-\text { motif }\right)}} \\
{[\% \text { cis }-1,4-\text { motif }]=\frac{\mathrm{A}(29.7 \mathrm{ppm})}{\mathrm{A}(29.7 \mathrm{ppm})+\mathrm{A}(32.1 \mathrm{ppm})}}
\end{gathered}
$$




\section{Putative polymerization reaction pathways}<smiles>c1ccc([C](c2ccccc2)c2ccccc2)cc1</smiles>

Trityl BArF 20<smiles></smiles>

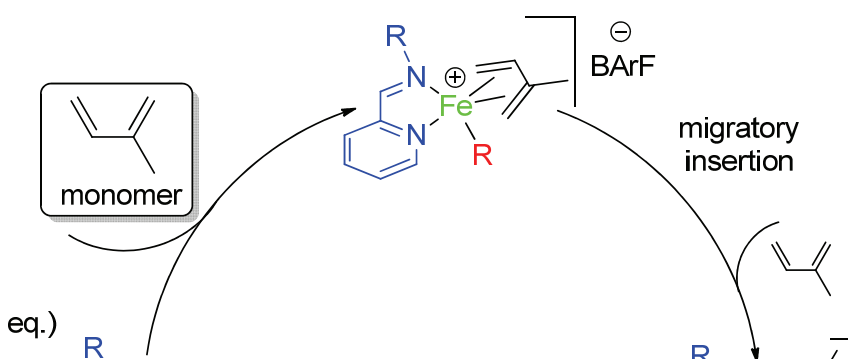<smiles></smiles>

1. $\mathrm{AIR}_{3}$ (3 eq.)

2. Trityl BArF (1 eq.)

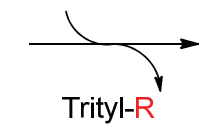

Fe-II

in apolar solvents
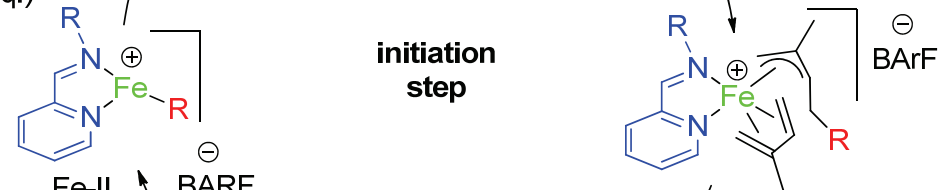

termination reaction proton transfer

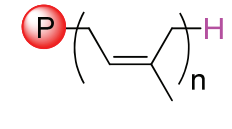

1,4-polyisoprene

Eventual side reaction:

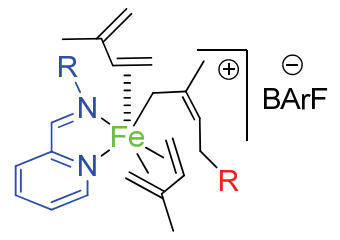

Coordination of a diene molecule as an olefin:

3,4 insertion

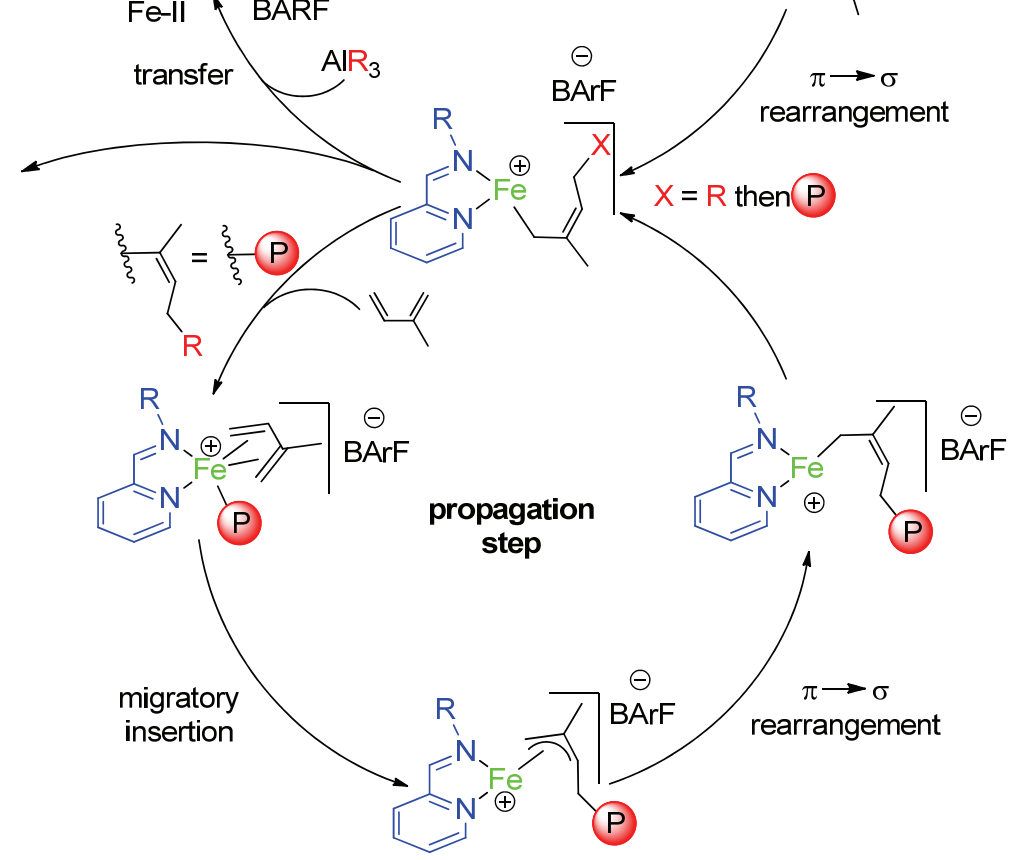




\section{Putative alkylation/de-alkylation pathways}

A molecule of $\mathrm{AlR}_{3}$ can form a bimetallic onium complex together with the iron center:<smiles>[R][R]1:[R]([Si]([R])([R])[R])nc2ccccn12</smiles>

dormant form<smiles>[Se]C1CC1</smiles>

ArF<smiles></smiles>

B

active form

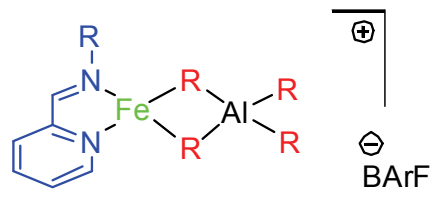

Formation of $\mathbf{A}$ :

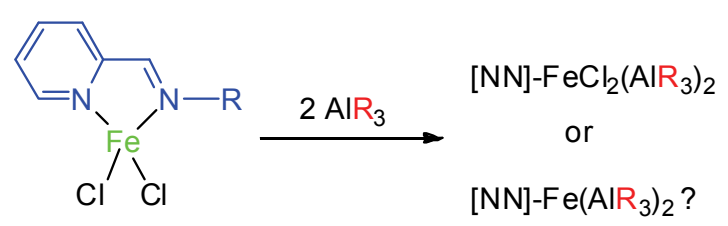

then $A$ when reacts with $\left[\mathrm{Ph}_{3} \mathrm{C}\right]\left[\mathrm{B}\left(\mathrm{C}_{6} \mathrm{~F}_{5}\right)_{4}\right]$ forming $\mathrm{Ph}_{3} \mathrm{CR}$
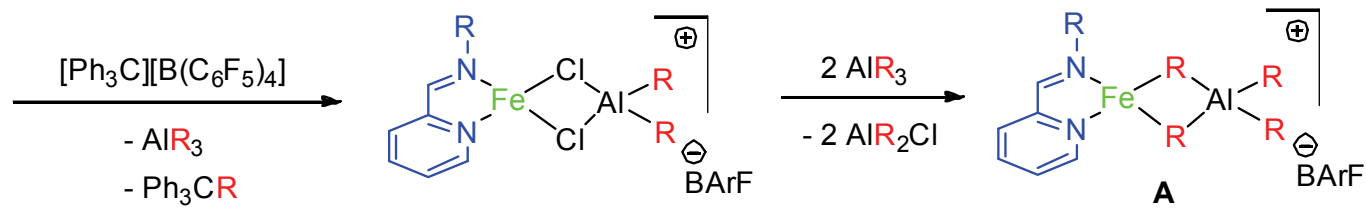

\section{Different isomeric motifs obtained during isoprene polymerization}

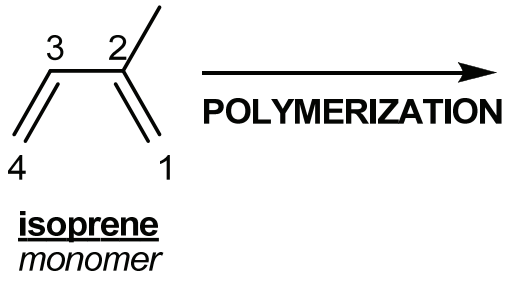<smiles>CCCCCCCCCCCC</smiles>

1,4-trans motif

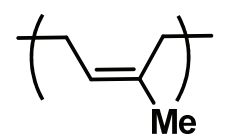

1,4-cis motif<smiles>C=C(C)C(CC)C(C)C</smiles>

3,4 motif<smiles>C=CC(CC)(CC)C(C)C</smiles>

1,2 motif not observed 
Photos depicting the aspect of the synthesized polyisoprenes
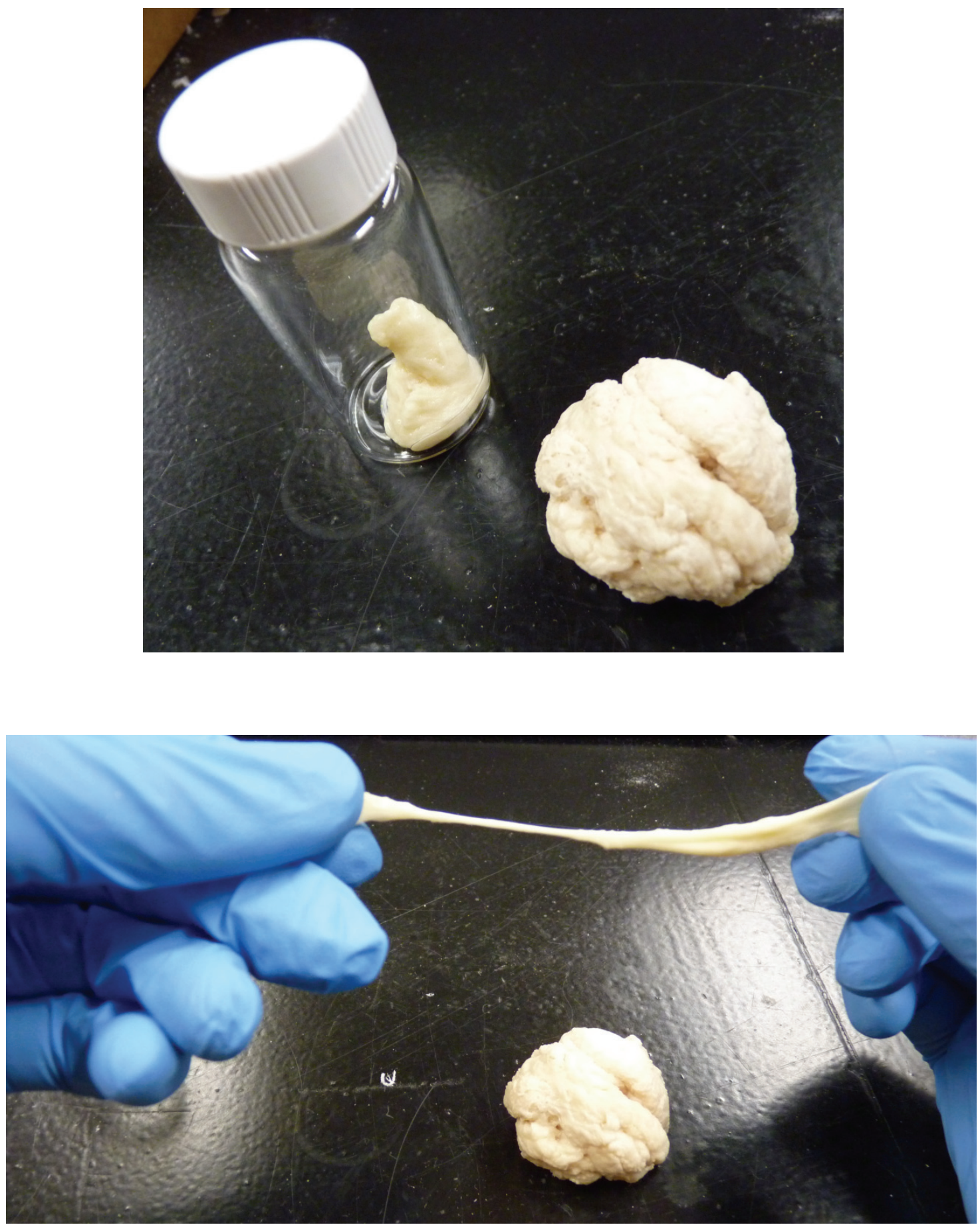


\section{Kinetic Profile of Polymerization}

Kinetic experiments were conducted according polymerization procedures depicted in examples 1 and 5 of the SI. Different aliquots were taken during the course of the reaction to determine conversion vs. time. Conversions were determined via ${ }^{1} \mathrm{H}$ NMR, using the characteristic chemical shifts of the olefinic protons of polyisoprene (5.12 and 4.6-4.8 ppm) and those of isoprene [6.45 (dd, $J=17.5 \mathrm{~Hz}, J=10.5 \mathrm{~Hz}, 1 \mathrm{H}), 5.18(\mathrm{~d}, J=17.5 \mathrm{~Hz}, 1 \mathrm{H}), 5.08(\mathrm{~d}, J=10.5 \mathrm{~Hz}, 1 \mathrm{H}), 4.9 \mathrm{ppm}$ $(\mathrm{m}, 2 \mathrm{H})$ and $1.85\left(\mathrm{t},{ }^{4} \mathrm{~J}=1.2 \mathrm{~Hz}\right)$.

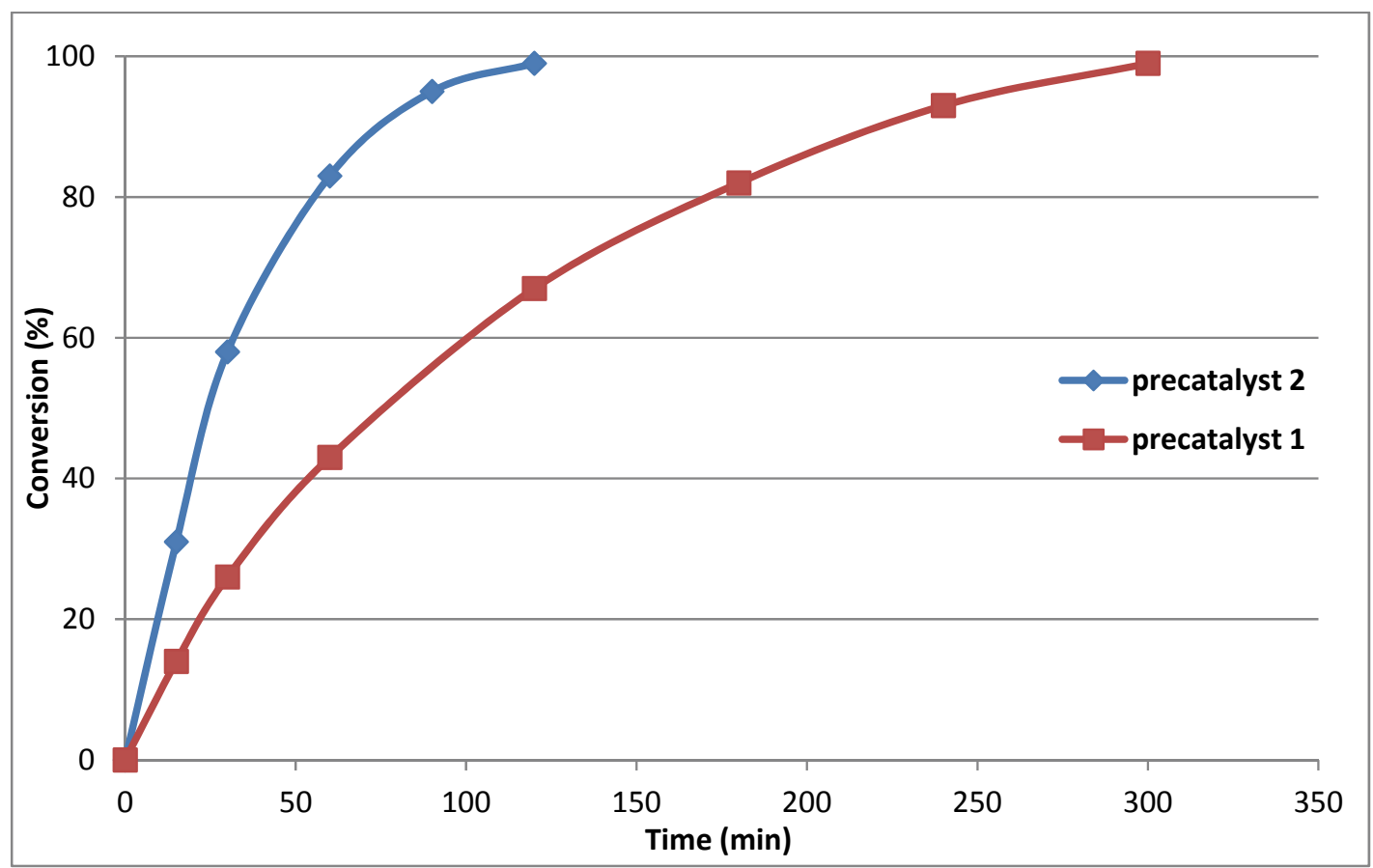

The formula used to determine conversion is the following:

$$
\begin{gathered}
\text { Conv. }(\%)=\frac{\text { Area normalized for polymer }}{\text { Area normalized for polymer }+ \text { Area normalized for monomer }} \\
\text { Conv. }(\%)=\frac{(A(5.05 \text { to } 5.25)-2 \times A(6.4 \text { to } 6.5))}{(A(5.05 \text { to5.25 })-2 \times A(6.4 \text { to } 6.5))+A(6.4 \text { to } 6.5)}
\end{gathered}
$$

The experiment with precatalyst 2 yields an activity of $1 \mathrm{~kg}$ polyisoprene $\cdot \mathrm{g}_{\mathrm{Fe}}{ }^{-1} \cdot \mathrm{h}^{-1}$ The experiment with precatalyst 1 yields an activity of $0.33 \mathrm{~kg}$ polyisoprene $\cdot \mathrm{g} \mathrm{Fe}^{-1} \cdot \mathrm{h}^{-1}$

These numbers were derived using pseudo-linear portions of the curves between 20 and $80 \%$ conversion (jump in conversion achieved in $50 \mathrm{~min}$ for precatalyst 2 and $150 \mathrm{~min}$ for precatalyst 1). 


\section{SEC Analysis}

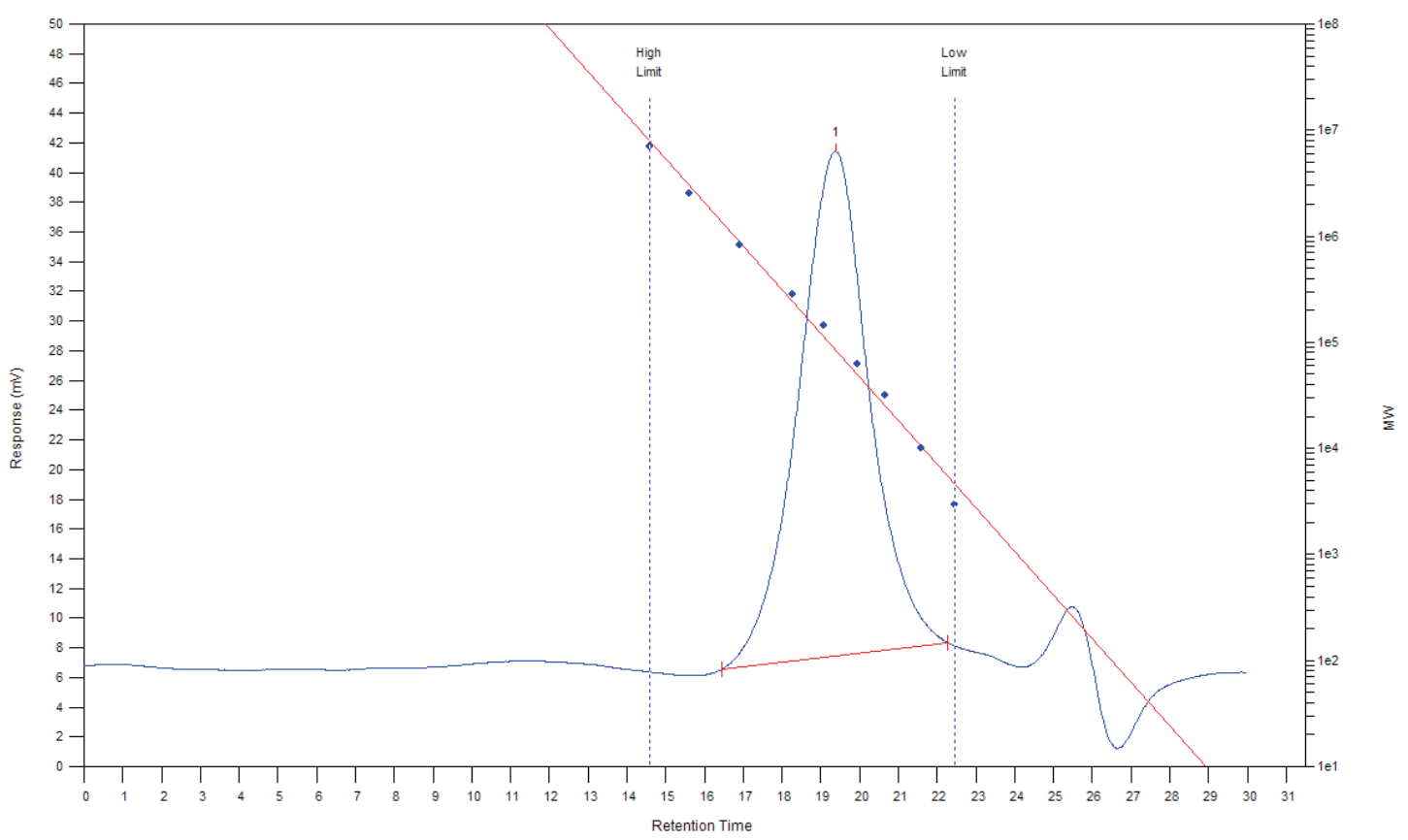

Figure S1. Size-exclusion chromatogram of trans-1,4-polyisoprene $M_{w}=125,000 \mathrm{~g} / \mathrm{mol}, D=2.0$. Baselines automatically generated by the software, polydispersity values might be slightly higher than shown (same comment for Figure S2).

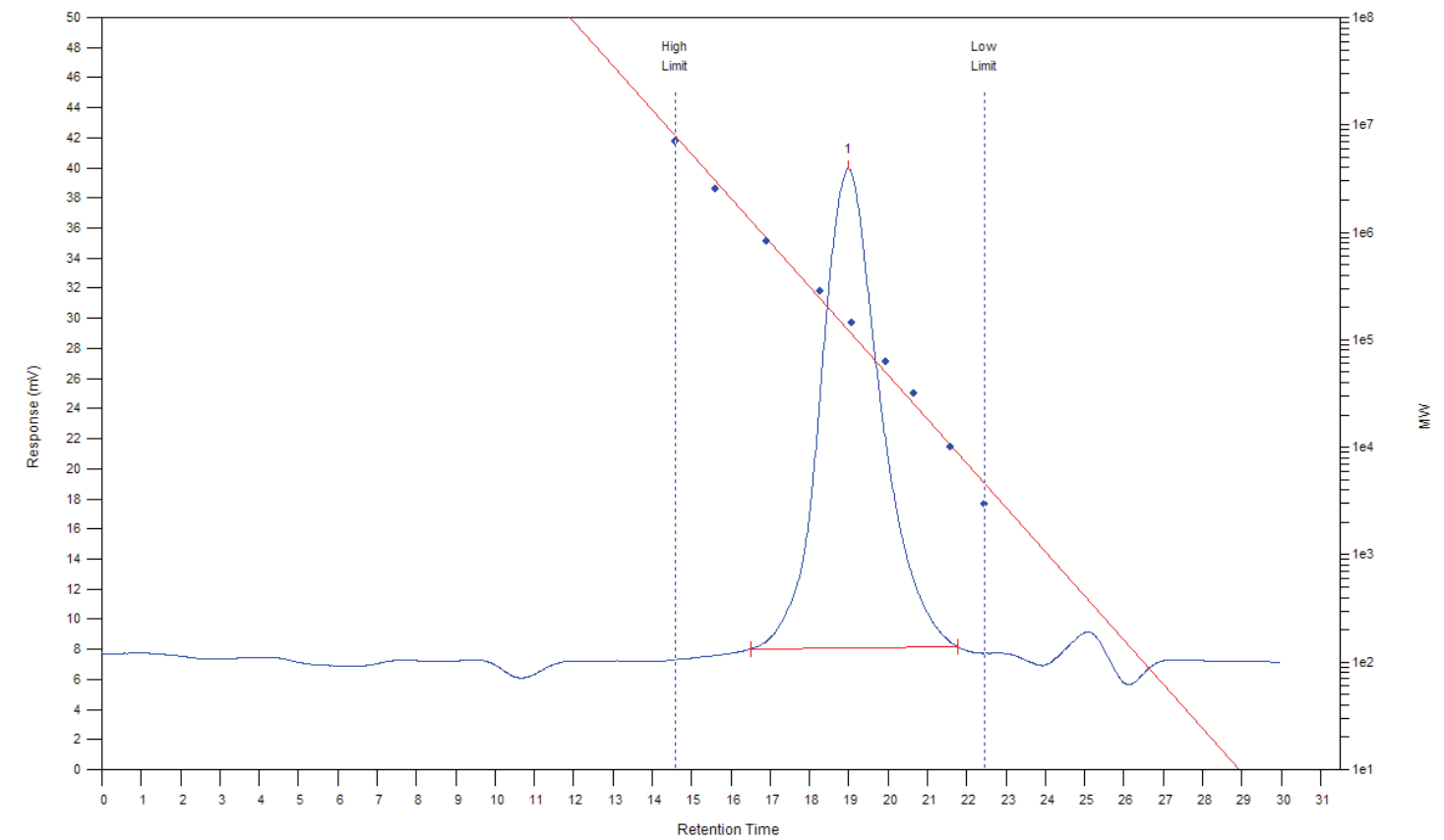

Figure S2. Size-exclusion chromatogram of $c i s-1,4$-polyisoprene $M_{w}=140,000 \mathrm{~g} / \mathrm{mol}, D=1.7$. 


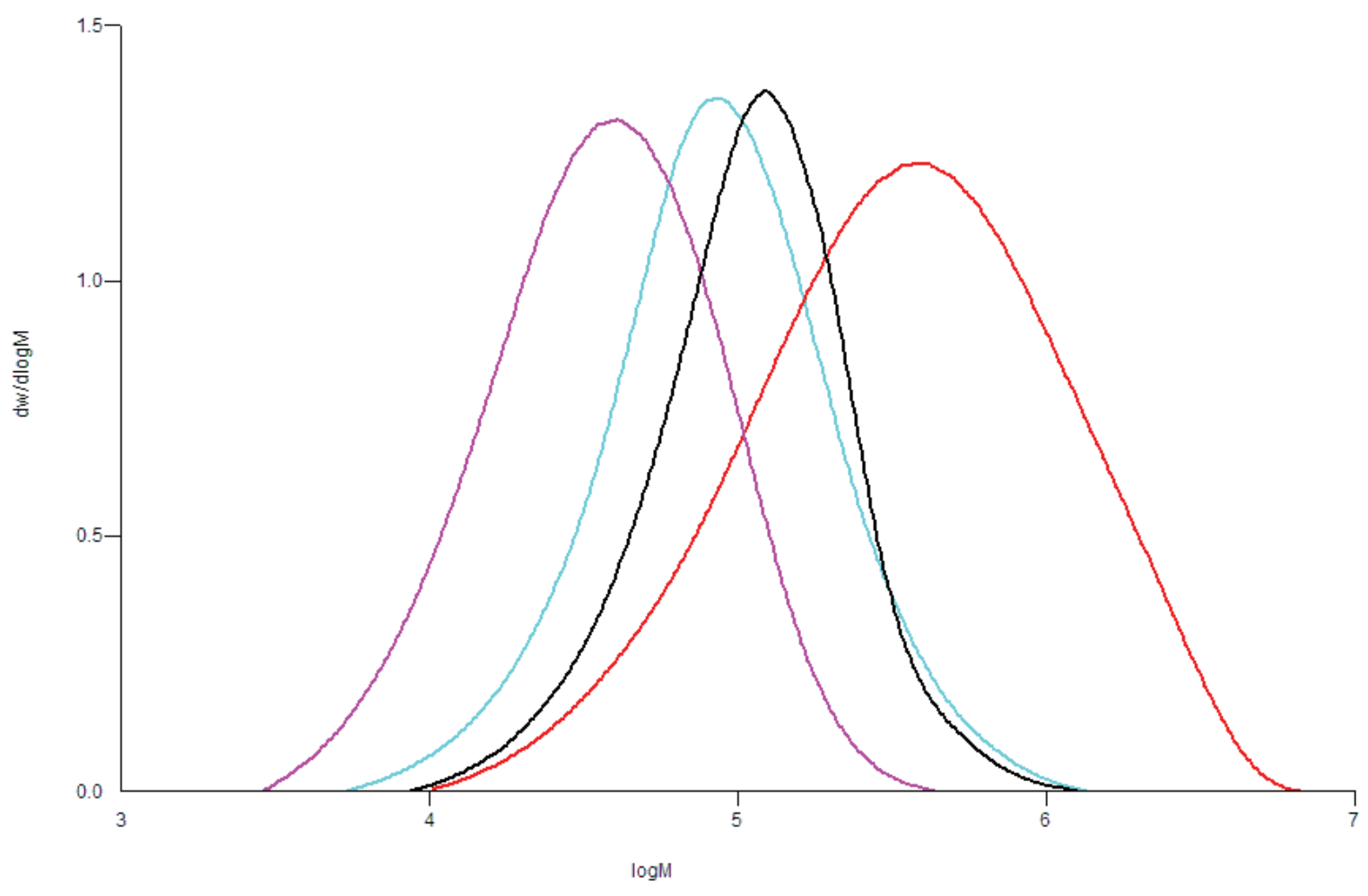

Figure S3. Molar mass distributions: living character of the Iron catalyzed polymerization of isoprene. The blue curve represents the SEC-M trace of chain extension of a pre-existing polymer of lower molar masses represented by the pink curve. Similarly, the red curve represents the chain extension to higher molar masses of a pre-existing polymer of medium molar masses represented by the black curve. 


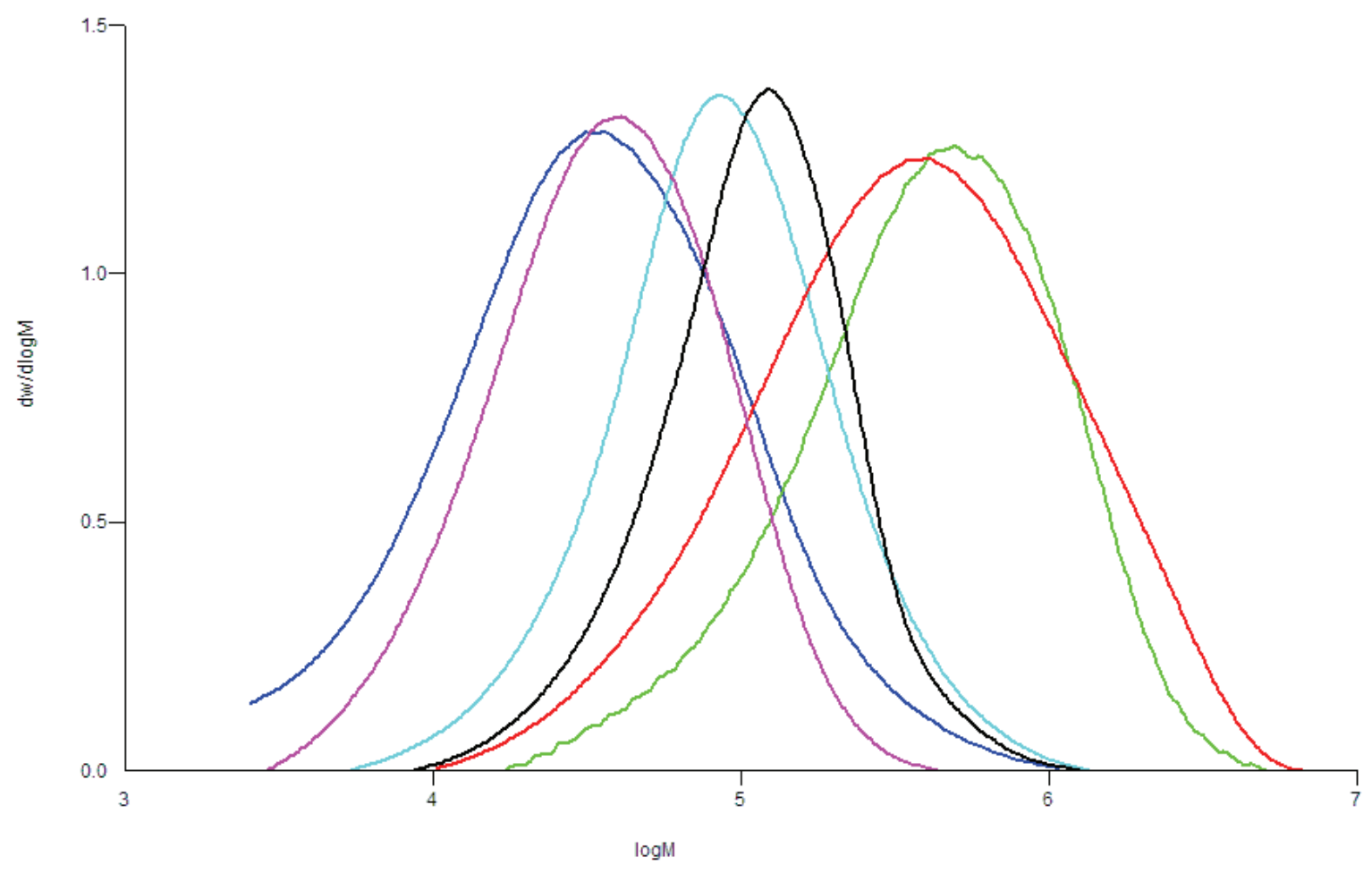

Figure S4. Accessible molar masses, obtained from the various polymerization reactions reported above varying the ratio [isoprene]/[Fe]. Green (example 8) and red (example 4) curves are obtained with a ratio of 5000. The black curve represents an aliquot of example 4, after $1 \mathrm{~h}$ of polymerization. The light blue (example 2) curve is obtained with a ratio of 2000 . The blue curve (example 1) is obtained with a ratio of 1000 . The pink curve is obtained represents an aliquot of example 2. 


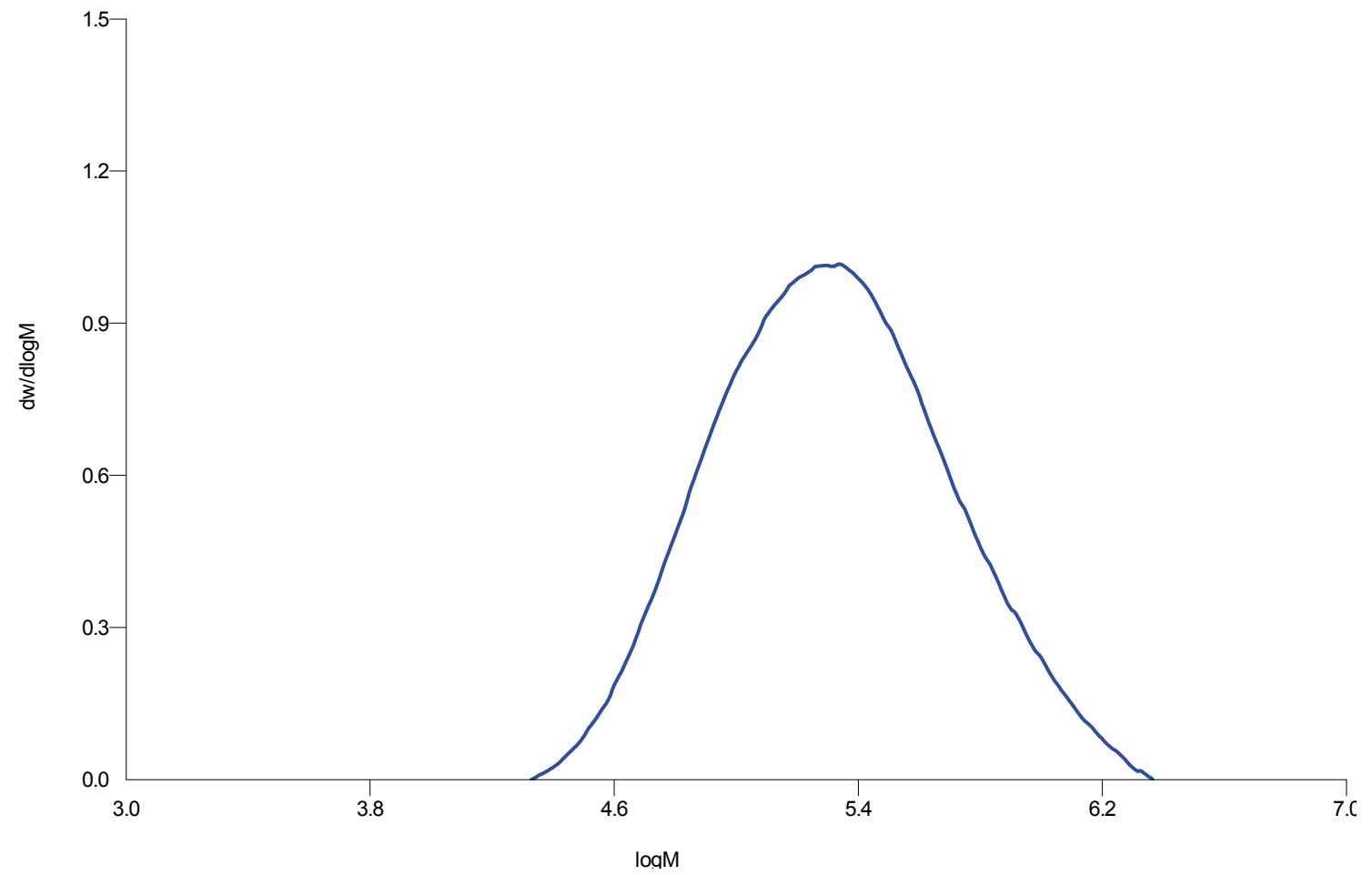

Figure S5. Size-exclusion chromatogram of trans-1,4-poly- $\beta$-myrcene $M_{w}=250,000 \mathrm{~g} / \mathrm{mol}, D=$ 2.1 .

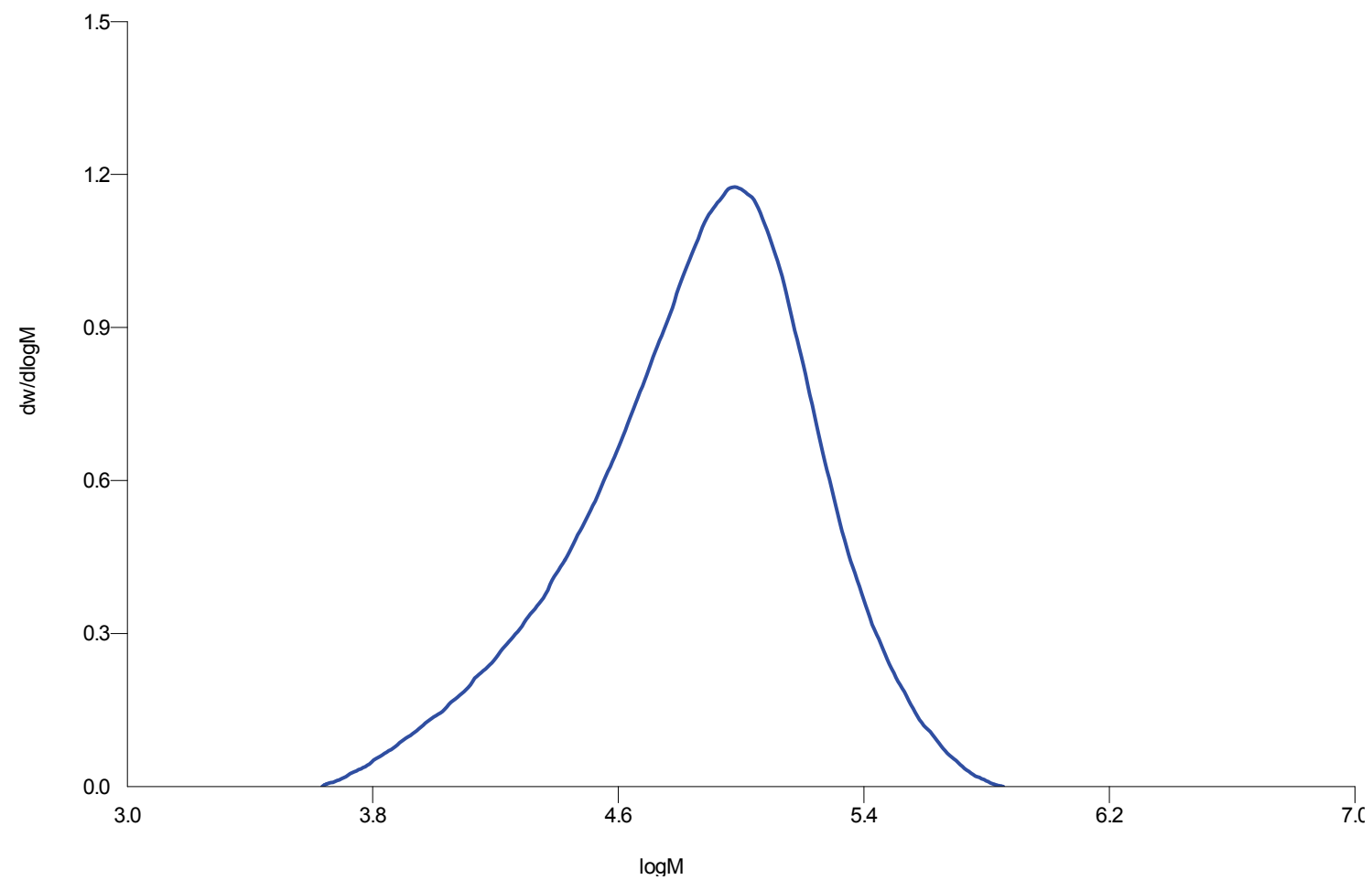

Figure S6. Size-exclusion chromatogram of trans-1,4-poly- $\beta$-farnesene $M_{w}=110,000 \mathrm{~g} / \mathrm{mol}, D=$ 1.5 . 


\section{GC Analysis}

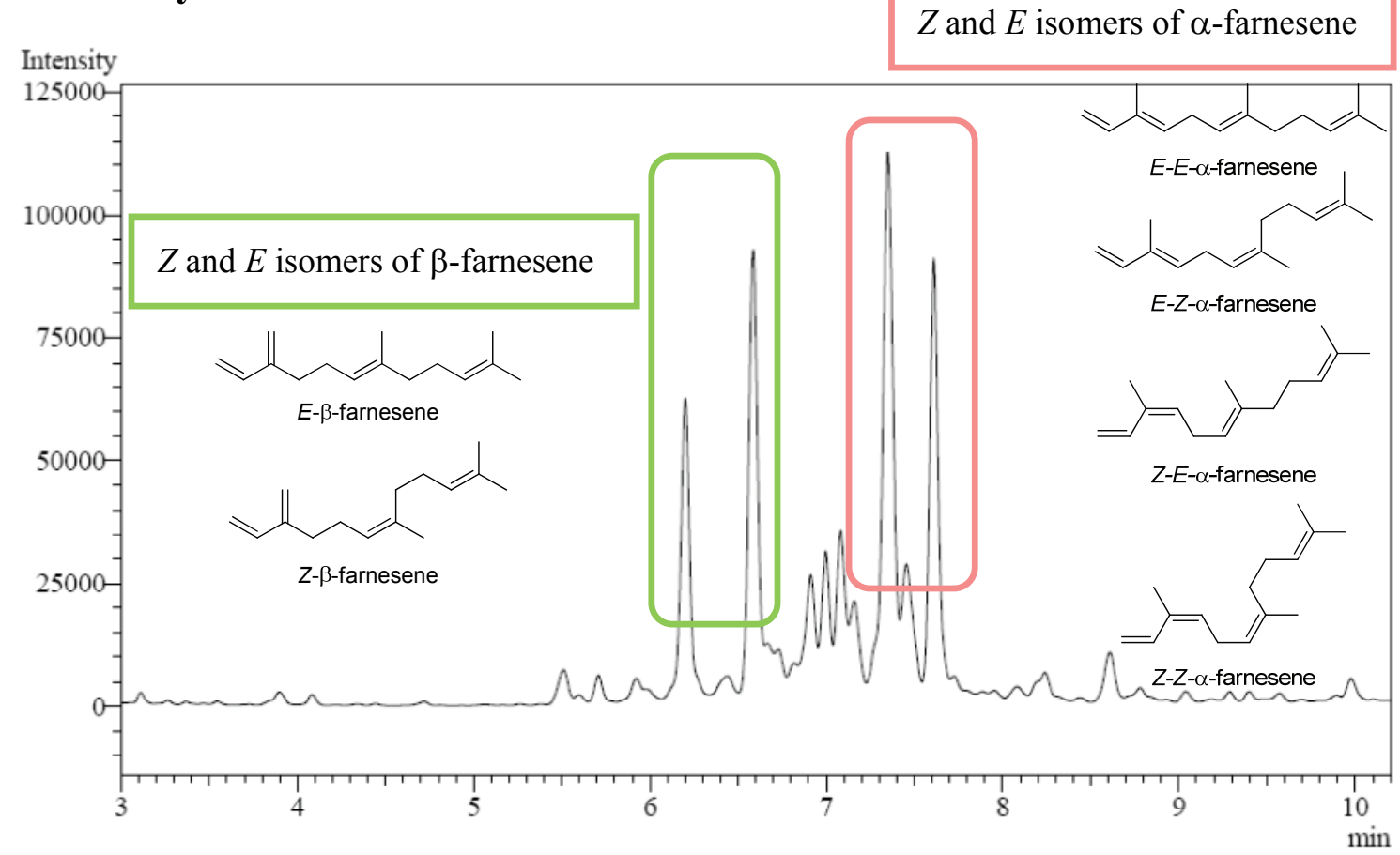

Figure S7. Gas chromatogram of the commercially available mixture of farnesene isomers (in green $\beta$-farnesene isomers, in pink two major isomers among the four possible isomers of $\alpha$ farnesene. $\beta$-farnesene isomers have lower bp ${ }^{\circ}$ than $\alpha$-farnesene counterparts. ${ }^{7}$

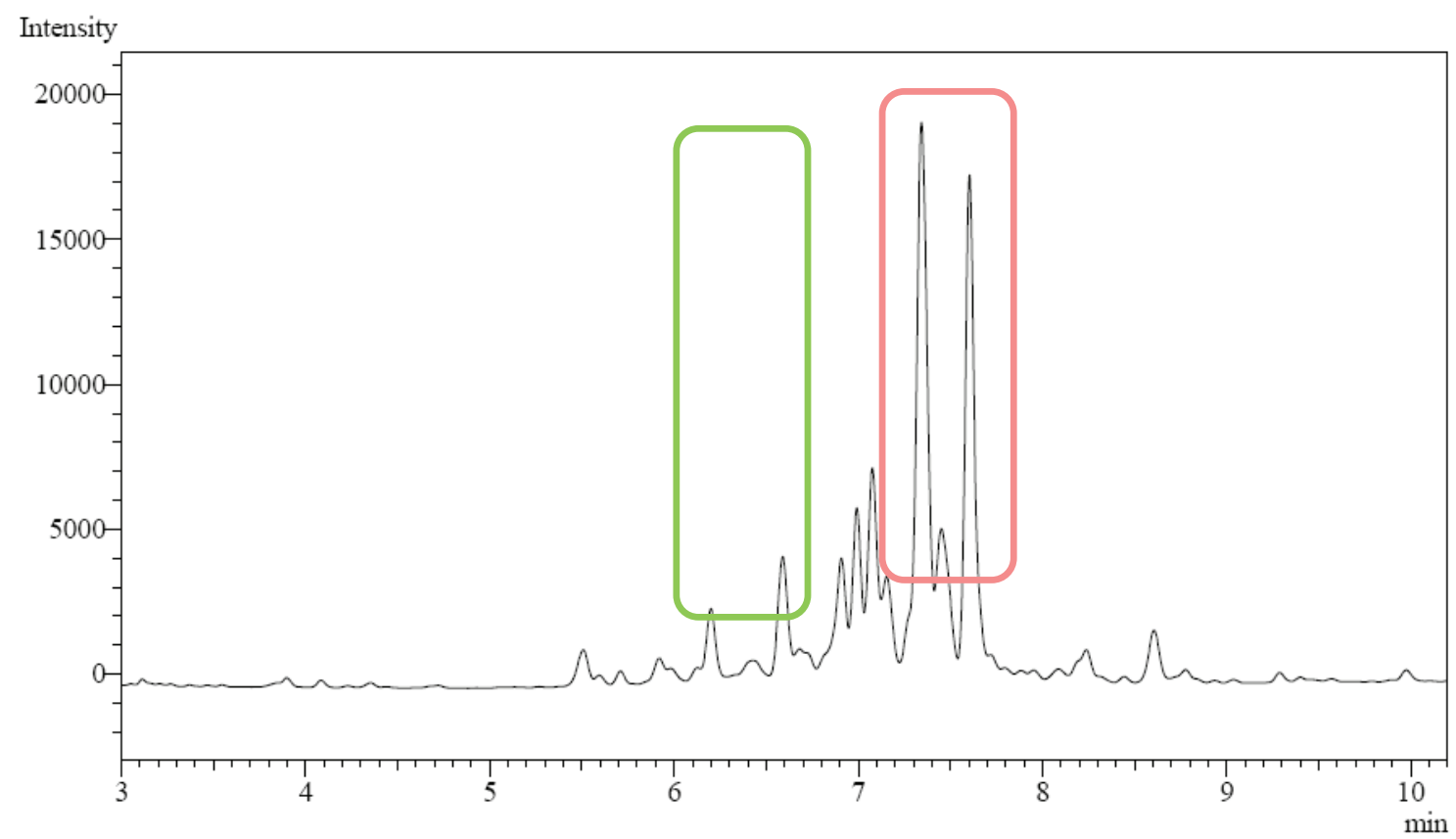

Figure S8. Gas chromatogram of the solution obtained after precipitation of the trans-1,4-poly$\beta$-farnesene (ex. 11): the two peaks corresponding to the $\beta$-isomers have almost disappeared.

${ }^{7}$ Wang, S. C.; Tseng, T. Y.; Huang, C. M.; Tsai, T. H. Journal of Chromatography B 2004, 812, 193-202 


\title{
X-Ray Crystallographic Analysis
}

\author{
iron(II) chloride complex 1 (CCDC 853130)
}

\section{Experimental}

The title compound crystallized as orange plates from a vapor diffusion of pentane into a $\mathrm{CH}_{2} \mathrm{Cl}_{2}$ solution at $23{ }^{\circ} \mathrm{C}$. A crystal $0.001 \mathrm{~mm} \times 0.050 \mathrm{~mm} \times 0.100 \mathrm{~mm}$ in size was selected, mounted on a nylon loop with Paratone-N oil, and transferred to a Bruker SMART APEX II DUO CCD diffractometer equipped with an Oxford Cryosystems nitrogen flow apparatus and $\mathrm{Cu} \mathrm{K} \alpha$ radiation $(\lambda=1.54178 \AA)$. The data collection method involved $1.0^{\circ}$ scans in $\omega$ at $30^{\circ}, 55^{\circ}, 90^{\circ}$, and $115^{\circ}$ in $2 \theta$. Data integration down to $0.84 \AA$ resolution was carried out using SAINT V7.46 (Bruker diffractometer, 2009) with reflection spot size optimization. Absorption corrections were made with the program SADABS (Bruker diffractometer, 2009). The structure was solved by direct methods and refined by least-squares methods against $F^{2}$ using SHELXS-97 and SHELXL97 (Sheldrick, 2008). Non-hydrogen atoms were refined anisotropically, and hydrogen atoms were allowed to ride on their respective atoms. Crystal data as well as details of data collection and refinement are summarized in Table 1 and geometric parameters are shown in Table 2. Ortep plots were produced with SHELXL-97 (Sheldrick, 2008).

\section{References}

Bruker AXS (2009). APEX2 v2009.3.0. Bruker Analytical X-ray Systems Inc., Madison, Wisconsin, USA.

Bruker AXS (2009). SADABS. Bruker Analytical X-ray Systems Inc., Madison, Wisconsin, USA.

Bruker AXS (2009). SAINT V7.46A. Bruker Analytical X-ray Systems Inc., Madison, Wisconsin, USA.

Sheldrick, G. M. Acta Cryst. (2008). A64, 112-122.

Creagh, D. C. \& McAuley, W. J. (1992). International Tables for Crystallography: Mathematical, Physical and Chemical Tables, Vol C, edited by A. J. C. Wilson, pp. 206-222. Dordrecht, The Netherlands: Kluwer.

Maslen, E. N., Fox, A. G. \& O'Keefe, M. A. (1992). International Tables for Crystallography: Mathematical, Physical and Chemical Tables, Vol C, edited by A. J. C. Wilson, pp. 476-516. Dordrecht, The Netherlands: Kluwer.

$\mathrm{R}(\mathrm{F})=\mathrm{R} 1=\Sigma\left\|\mathrm{F}_{\mathrm{o}}|-| \mathrm{F}_{\mathrm{c}}\right\| / \Sigma\left|\mathrm{F}_{\mathrm{o}}\right|, \mathrm{wR}\left(\mathrm{F}^{2}\right)=\mathrm{wR} 2=\left[\Sigma \mathrm{w}\left(\mathrm{F}_{\mathrm{o}}{ }^{2}-\mathrm{F}_{\mathrm{c}}{ }^{2}\right)^{2} / \Sigma \mathrm{w}\left(\mathrm{F}_{\mathrm{o}}{ }^{2}\right)^{2}\right]^{1 / 2}$, and $\mathrm{S}=$ Goodness-of-fit on $\mathrm{F}^{2}=\left[\Sigma \mathrm{W}\left(\mathrm{F}_{\mathrm{o}}{ }^{2}-\mathrm{F}_{\mathrm{c}}{ }^{2}\right)^{2} /(\mathrm{n}-\mathrm{p})\right]^{1 / 2}$, where $\mathrm{n}$ is the number of reflections and $\mathrm{p}$ is the number of parameters refined. 


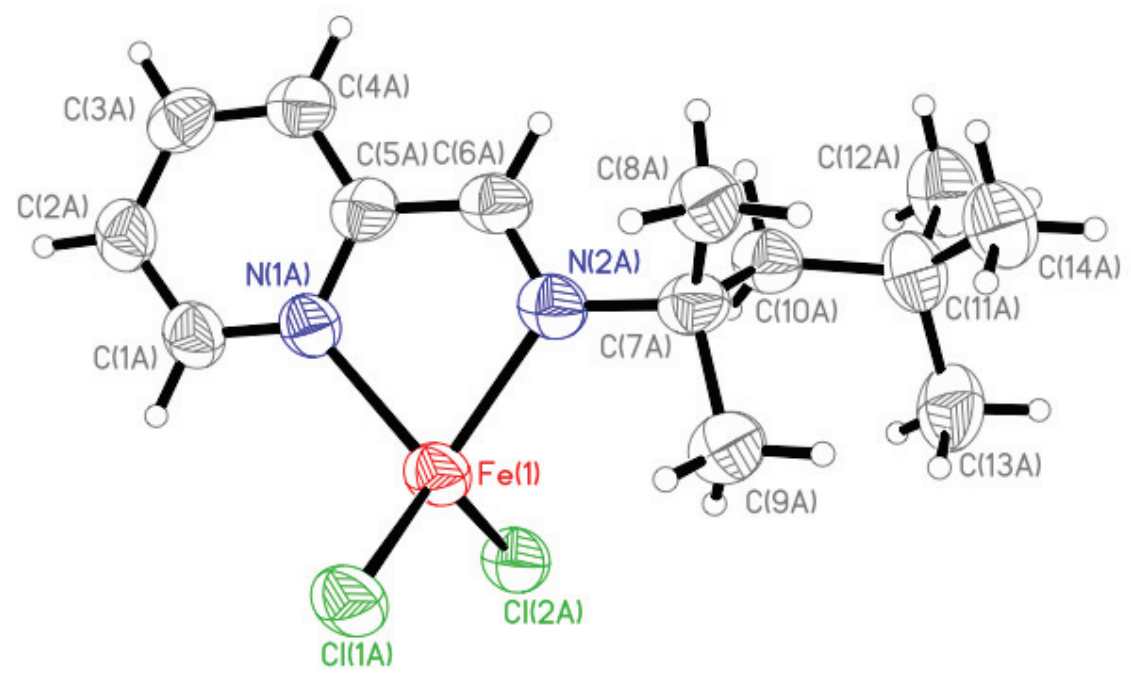

Figure S9. The X-ray structure of (E)-2,4,4-trimethyl- $N$-(pyridin-2-ylmethylene)pentan-2-amine iron(II) chloride 1 with hydrogens and with the atom labeling scheme employed. The nonhydrogen atoms are depicted with $50 \%$ probability ellipsoids.

Table S1. Crystal data and structure refinement for (E)-2,4,4-trimethyl- $N$-(pyridin-2ylmethylene)pentan-2-amine iron(II) chloride.

\begin{tabular}{ll}
\hline Identification code & $\mathrm{CCDC} 853130$ \\
Chemical formula & $\mathrm{C}_{14} \mathrm{H}_{22} \mathrm{Cl}_{2} \mathrm{FeN}_{2}$ \\
Molecular weight & 345.09 \\
Crystal system, space group & Triclinic, $P-1$ \\
Temperature (K) & 100 \\
$a, b, c(\AA)$ & $8.0412(4), 12.8066(7), 16.8314(10)$ \\
$\alpha, \beta, \gamma\left({ }^{\circ}\right)$ & $99.106(3), 97.796(3), 97.609(4)$ \\
$V\left(\AA^{3}\right)$ & $1674.53(16)$ \\
\hline
\end{tabular}


Z 4

Radiation type

$\mathrm{Cu} K \alpha$

$\mu\left(\mathrm{mm}^{-1}\right)$

10.06

Crystal size (mm)

$0.10 \times 0.05 \times 0.01$

Data collection

Diffractometer

Bruker D8 goniometer with CCD area detector diffractometer

Absorption correction

Multi-scan, SADABS (Sheldrick,2008)

$T_{\min }, T_{\max }$

$0.036,0.633$

No. of measured, 26716, 5572, 3897

independent and observed $[I$

$>2 \sigma(I)]$ reflections

$R_{\text {int }}$

0.085

Refinement

$R\left[F^{2}>2 \sigma\left(F^{2}\right)\right], w R\left(F^{2}\right), S \quad 0.079,0.204,1.07$

No. of reflections

No. of parameters

No. of restraints

0

$\mathrm{H}$-atom treatment

$\mathrm{H}$-atom parameters constrained

$\Delta \rho_{\max }, \Delta \rho_{\min }\left(\mathrm{e} \AA^{-3}\right)$

$1.12,-0.62$

\section{Iron(II) chloride complex 2 (CCDC 853131)}

\section{Experimental}

The title compound crystallized as green needles from a vapor diffusion of diethyl ether into a $\mathrm{CH}_{2} \mathrm{Cl}_{2}$ solution at $-35{ }^{\circ} \mathrm{C}$. A crystal $0.01 \mathrm{~mm} \times 0.01 \mathrm{~mm} \times 0.05 \mathrm{~mm}$ in size was selected, mounted on a nylon loop with Paratone-N oil, and transferred to a Bruker SMART APEX II DUO $\mathrm{CCD}$ diffractometer equipped with an Oxford Cryosystems nitrogen flow apparatus and $\mathrm{Cu} \mathrm{Ka}$ radiation $(\lambda=1.54178 \AA)$. The data collection method involved $1.0^{\circ}$ scans in $\omega$ at $30^{\circ}, 55^{\circ}, 90^{\circ}$, and $115^{\circ}$ in $2 \theta$. Data integration down to $0.84 \AA$ resolution was carried out using SAINT V7.46 (Bruker diffractometer, 2009) with reflection spot size optimization. Absorption corrections were made with the program SADABS (Bruker diffractometer, 2009). The crystal diffracted weakly, resulting in the high $\mathrm{R}_{\text {int }}$. Two partial solvent molecules, dichloromethane and diethyl ether, were 
removed using Platon Squeeze, because they were difficult to locate on the difference map. The structure was solved by direct methods and refined by least-squares methods against $F^{2}$ using SHELXS-97 and SHELXL-97 (Sheldrick, 2008). Non-hydrogen atoms were refined anisotropically, and hydrogen atoms were allowed to ride on their respective atoms. Crystal data as well as details of data collection and refinement are summarized in Table 1 and geometric parameters are shown in Table 2. Ortep plots were produced with SHELXL-97 (Sheldrick, 2008).

\section{References}

Bruker AXS (2009). APEX2 v2009.3.0. Bruker Analytical X-ray Systems Inc., Madison, Wisconsin, USA.

Bruker AXS (2009). SADABS. Bruker Analytical X-ray Systems Inc., Madison, Wisconsin, USA.

Bruker AXS (2009). SAINT V7.46A. Bruker Analytical X-ray Systems Inc., Madison, Wisconsin, USA.

Sheldrick, G. M. Acta Cryst. (2008). A64, 112-122.

Creagh, D. C. \& McAuley, W. J. (1992). International Tables for Crystallography: Mathematical, Physical and Chemical Tables, Vol C, edited by A. J. C. Wilson, pp. 206-222. Dordrecht, The Netherlands: Kluwer.

Maslen, E. N., Fox, A. G. \& O'Keefe, M. A. (1992). International Tables for Crystallography: Mathematical, Physical and Chemical Tables, Vol C, edited by A. J. C. Wilson, pp. 476-516. Dordrecht, The Netherlands: Kluwer.

$\mathrm{R}(\mathrm{F})=\mathrm{R} 1=\Sigma\left\|\mathrm{F}_{\mathrm{o}}\left|-\mathrm{F}_{\mathrm{c}} \| / \Sigma\right| \mathrm{F}_{\mathrm{o}} \mid, \mathrm{wR}\left(\mathrm{F}^{2}\right)=\mathrm{wR} 2=\left[\Sigma \mathrm{w}\left(\mathrm{F}_{\mathrm{o}}^{2}-\mathrm{F}_{\mathrm{c}}^{2}\right)^{2} / \Sigma \mathrm{w}\left(\mathrm{F}_{\mathrm{o}}^{2}\right)^{2}\right]^{1 / 2}\right.$, and $\mathrm{S}=$ Goodness-of-fit on $\mathrm{F}^{2}=\left[\Sigma \mathrm{w}\left(\mathrm{F}_{\mathrm{o}}{ }^{2}-\mathrm{F}_{\mathrm{c}}{ }^{2}\right)^{2} /(\mathrm{n}-\mathrm{p})\right]^{1 / 2}$, where $\mathrm{n}$ is the number of reflections and $\mathrm{p}$ is the number of parameters refined. 


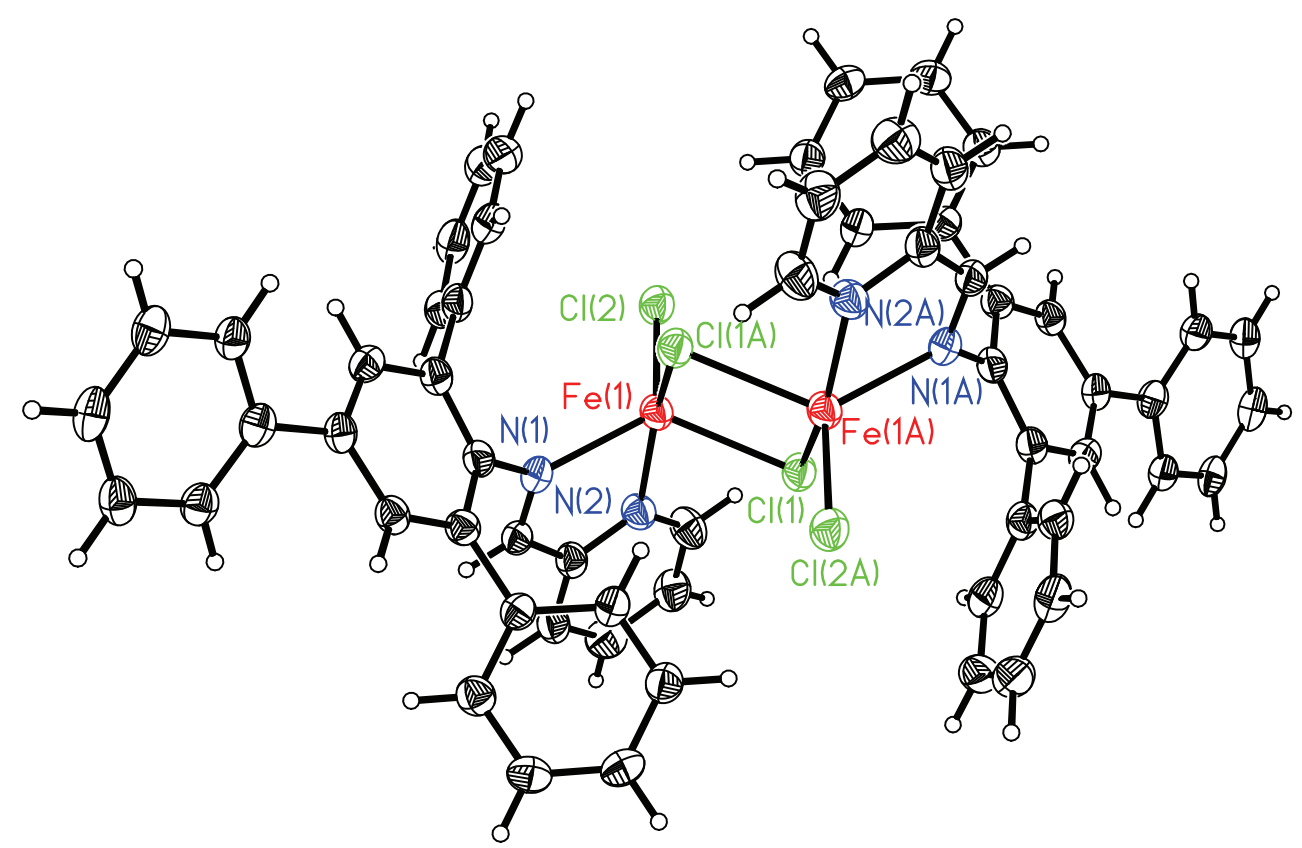

Figure S10. The X-ray structure of (E)-3,5-diphenyl- $N$-(pyridin-2-ylmethylene)biphenyl-2-amine iron(II) chloride 2 with hydrogens and with the atom labeling scheme employed for heteroatoms. The nonhydrogen atoms are depicted with $50 \%$ probability ellipsoids. 


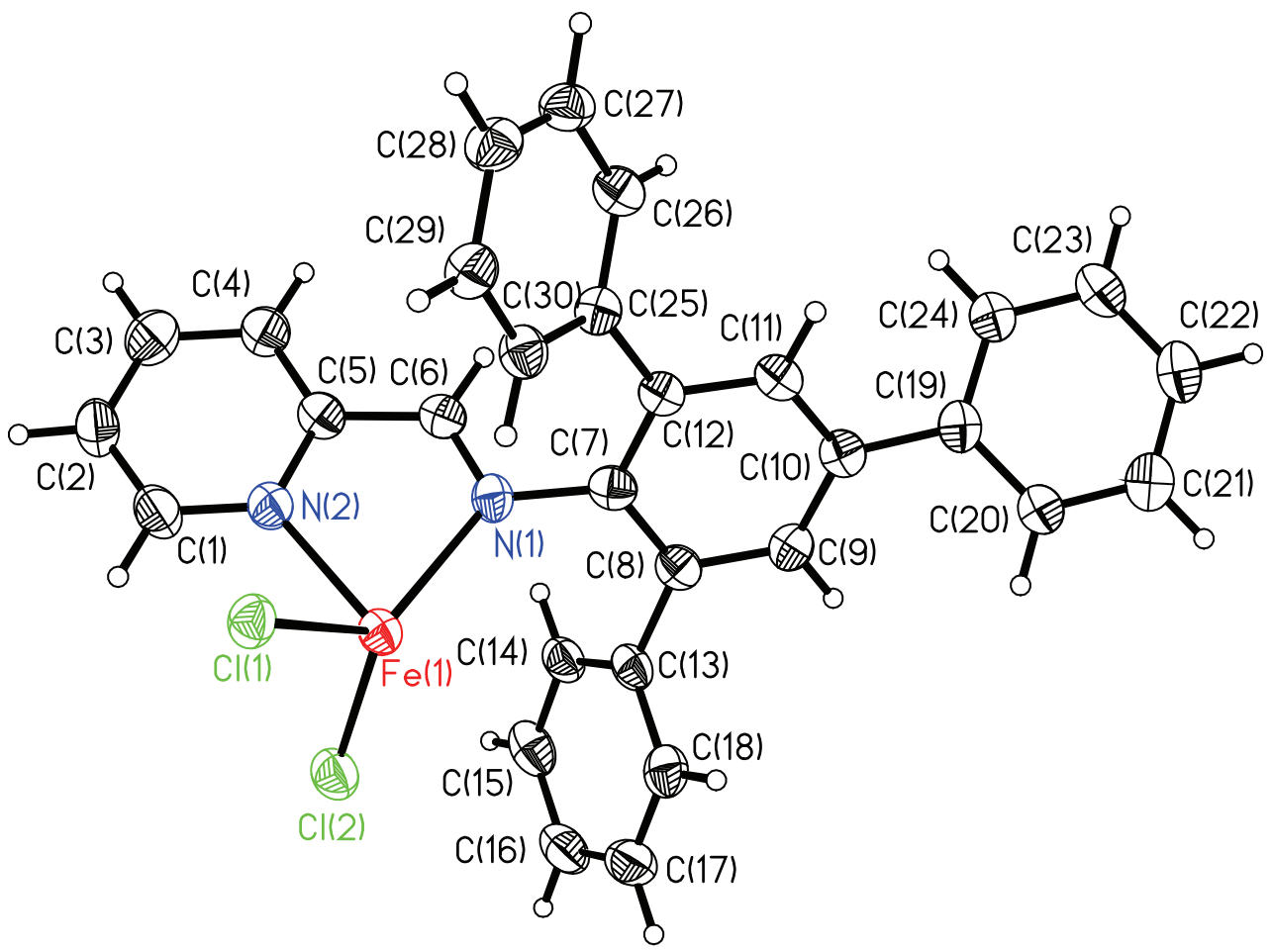

Figure S11. The X-ray structure of one half of the dimeric unit of (E)-3,5-diphenyl- $N$-(pyridin-2ylmethylene)biphenyl-2-amine iron(II) chloride 2 with hydrogens and with the atom labeling scheme employed. The nonhydrogen atoms are depicted with $50 \%$ probability ellipsoids.

Table S2. Crystal data and structure refinement for (E)-2,4,4-trimethyl- $N$-(pyridin-2ylmethylene)pentan-2-amine iron(II) chloride.

\begin{tabular}{ll}
\hline Identification code & $\mathrm{CCDC} 853131$ \\
Chemical formula & $\mathrm{C}_{60} \mathrm{H}_{44} \mathrm{Cl}_{4} \mathrm{Fe}_{2} \mathrm{~N}_{4}$ \\
$M_{\mathrm{r}}$ & 1074.49 \\
Crystal system, space group & Orthorhombic, Pccn \\
Temperature (K) & 100 \\
$a, b, c(\AA)$ & $19.6880(16), 28.115(2), 10.4622(9)$ \\
$V\left(\AA^{3}\right)$ & $5791.2(8)$ \\
$Z$ & 4 \\
\hline
\end{tabular}




\begin{tabular}{ll}
\hline $\begin{array}{l}\text { Radiation type } \\
\mu\left(\mathrm{mm}^{-1}\right)\end{array}$ & $\mathrm{CuK \alpha}$ \\
Crystal size $(\mathrm{mm})$ & 6.01 \\
Data collection & $0.05 \times 0.01 \times 0.01$ \\
& \\
Diffractometer & $\begin{array}{l}\text { Bruker D8 goniometer with CCD area } \\
\text { detector diffractometer }\end{array}$ \\
Absorption correction & Multi-scan, SADABS (Sheldrick, 2008) \\
$T_{\min }, T_{\max }$ & $0.753,0.942$
\end{tabular}

No. of measured, independent and observed $[I$

$>2 \sigma(I)]$ reflections

$69244,5053,3940$

$R_{\text {int }}$

0.131

Refinement

$R\left[F^{2}>2 \sigma\left(F^{2}\right)\right], w R\left(F^{2}\right), S$

$0.062,0.151,1.10$

No. of reflections

5053

No. of parameters

316

No. of restraints

0

$\mathrm{H}$-atom treatment

$\mathrm{H}$-atom parameters constrained

$\Delta \rho_{\max }, \Delta \rho_{\min }\left(\mathrm{e} \AA^{-3}\right)$

$0.92,-0.50$ 


\section{Spectroscopic Data (Mössbauer analysis)}

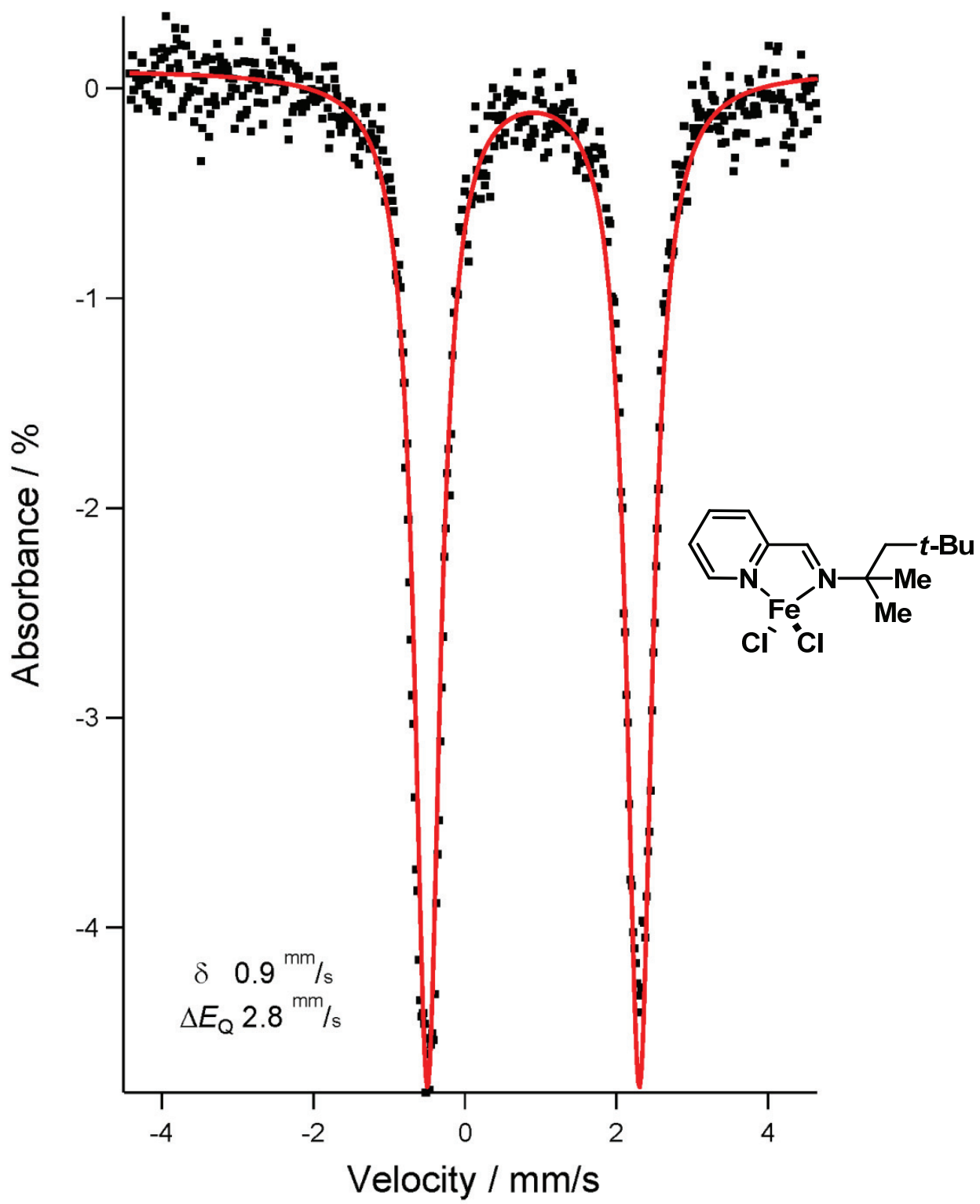

Figure S12. Mössbauer spectrum of (E)-2,4,4-trimethyl- $N$-(pyridin-2-ylmethylene)pentan-2amine iron(II) chloride (1) at $90 \mathrm{~K}$. 


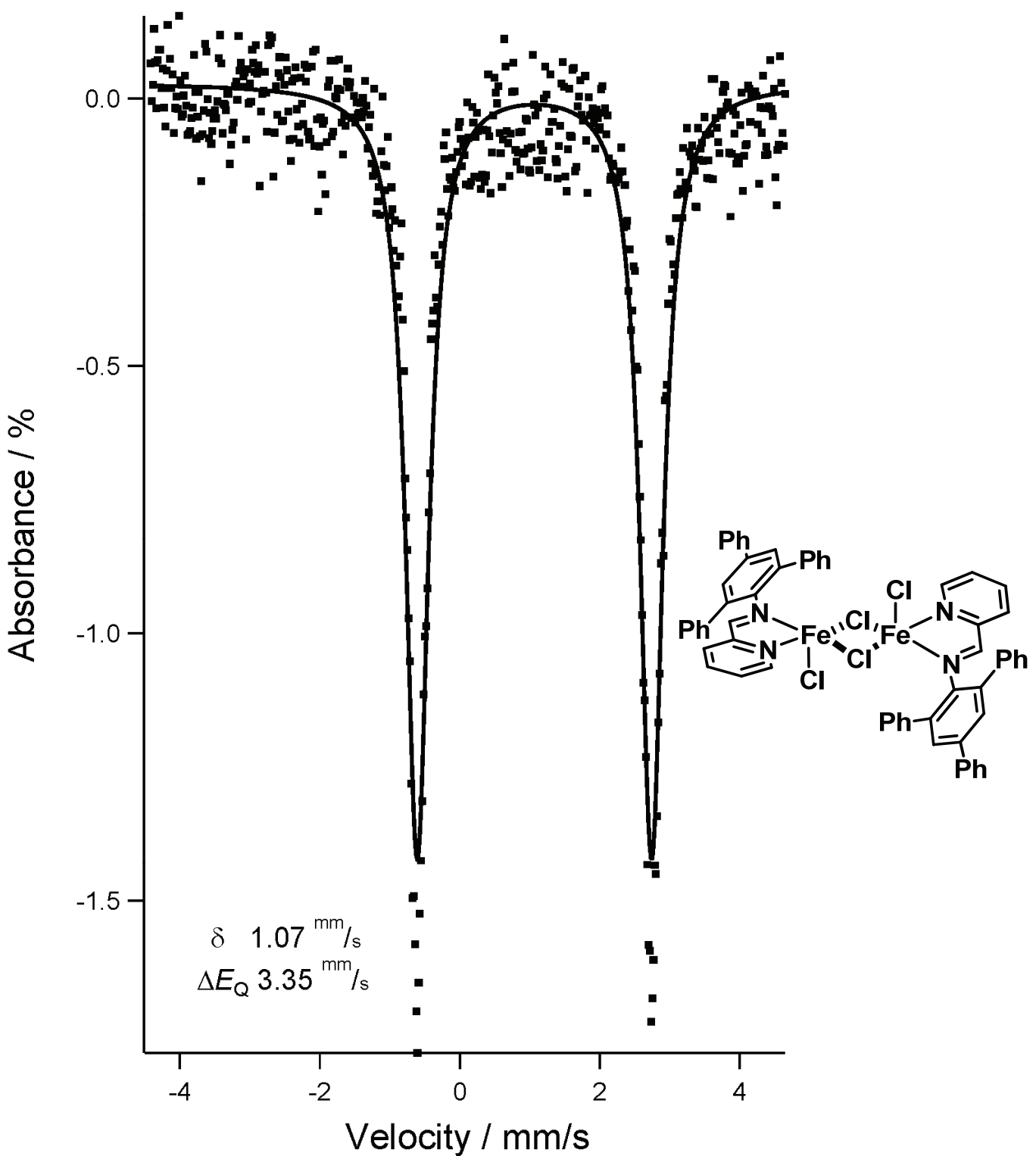

Figure S13. Mössbauer spectrum of (E)-3,5-diphenyl- $N$-(pyridin-2-ylmethylene)biphenyl-2amine iron(II) chloride (2) at $90 \mathrm{~K}$. 


\section{Spectroscopic Data (NMR analysis)}

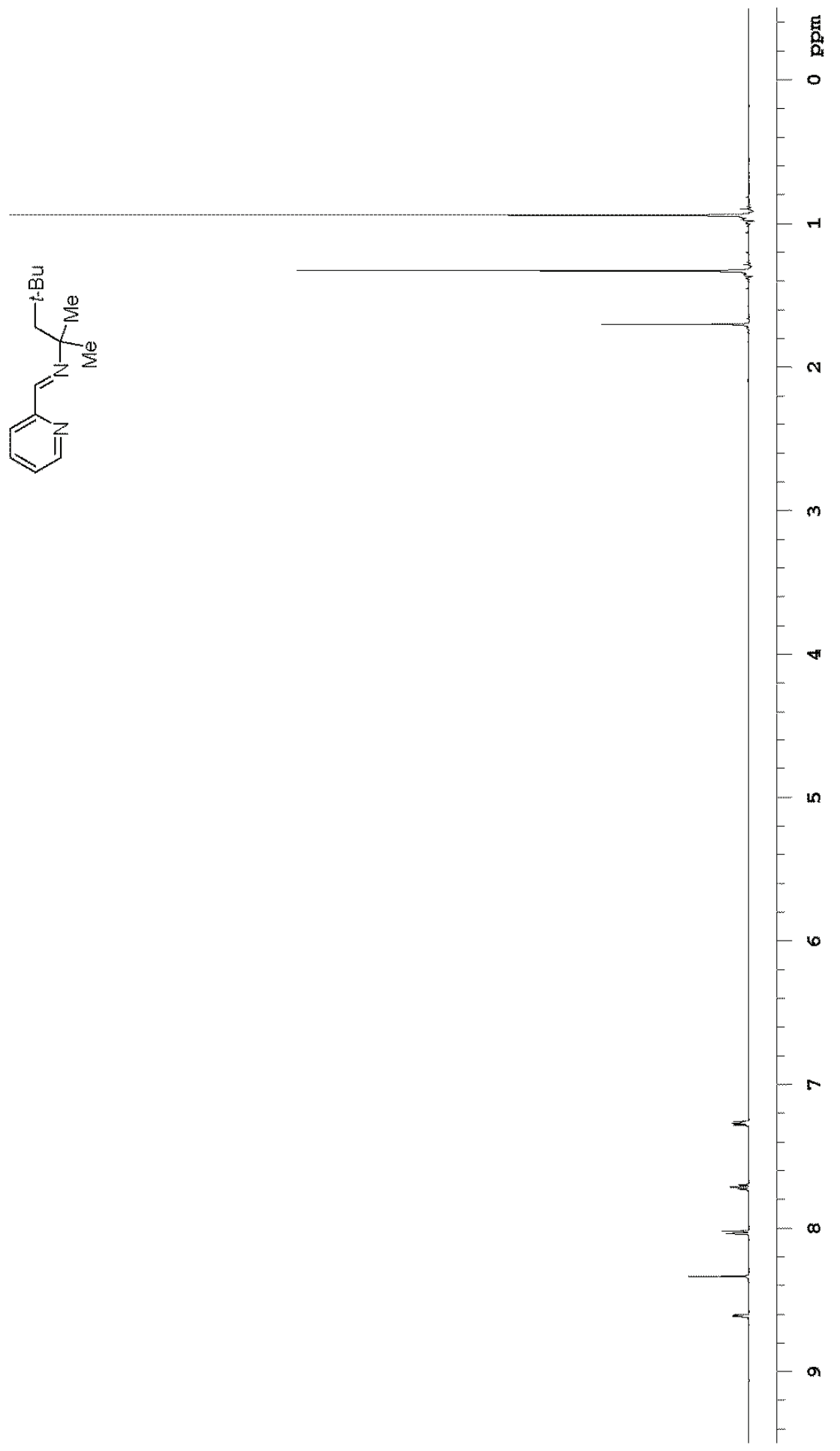

NMR 1: ${ }^{1} \mathrm{H}$ NMR spectrum $\left(500 \mathrm{MHz}, \mathrm{CDCl}_{3}, 25^{\circ} \mathrm{C}\right)$ of $\mathbf{S 1}$ 


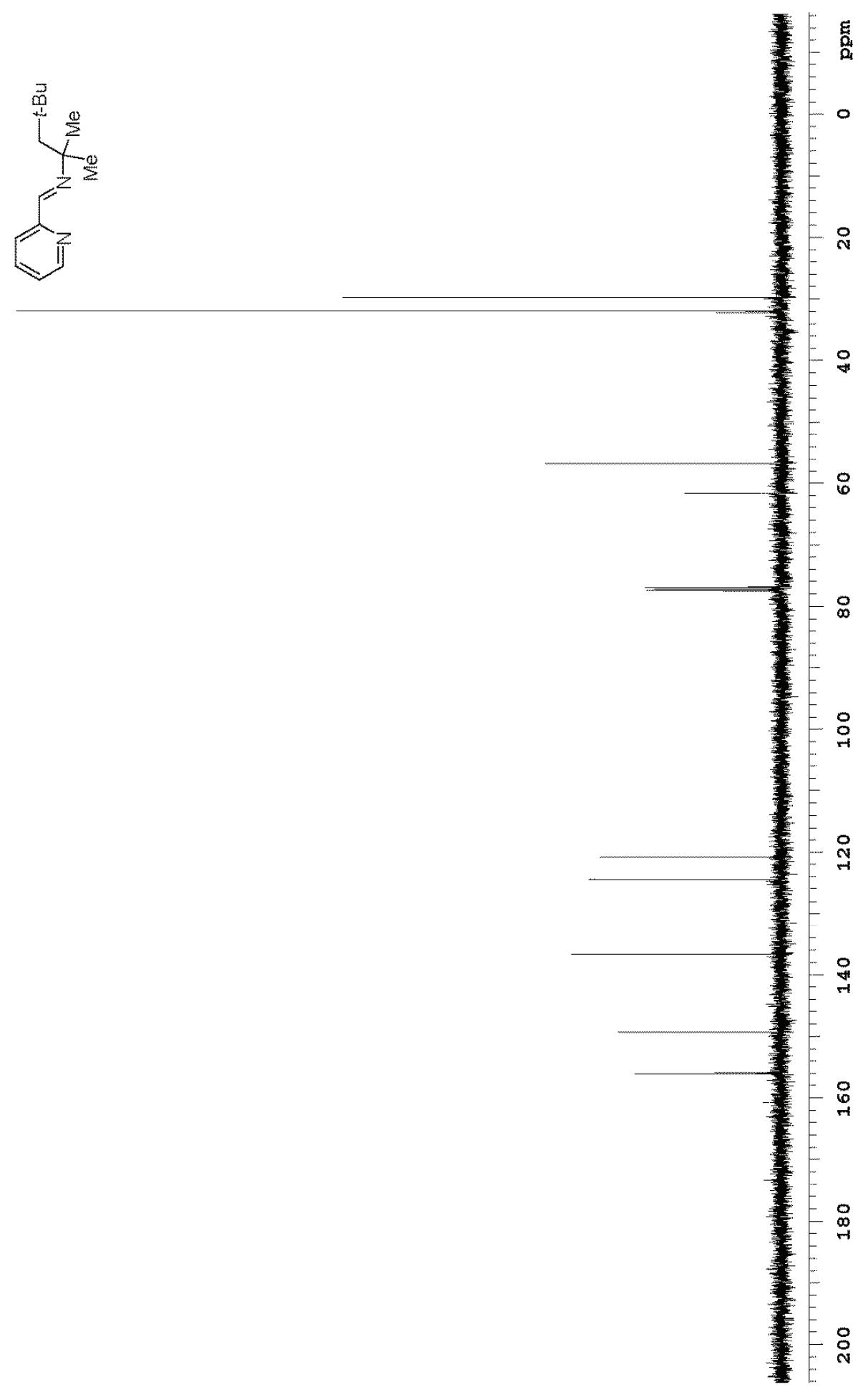

NMR 2: ${ }^{13} \mathrm{C}$ NMR spectrum $\left(125 \mathrm{MHz}, \mathrm{CDCl}_{3}, 25^{\circ} \mathrm{C}\right)$ of $\mathbf{S 1}$ 


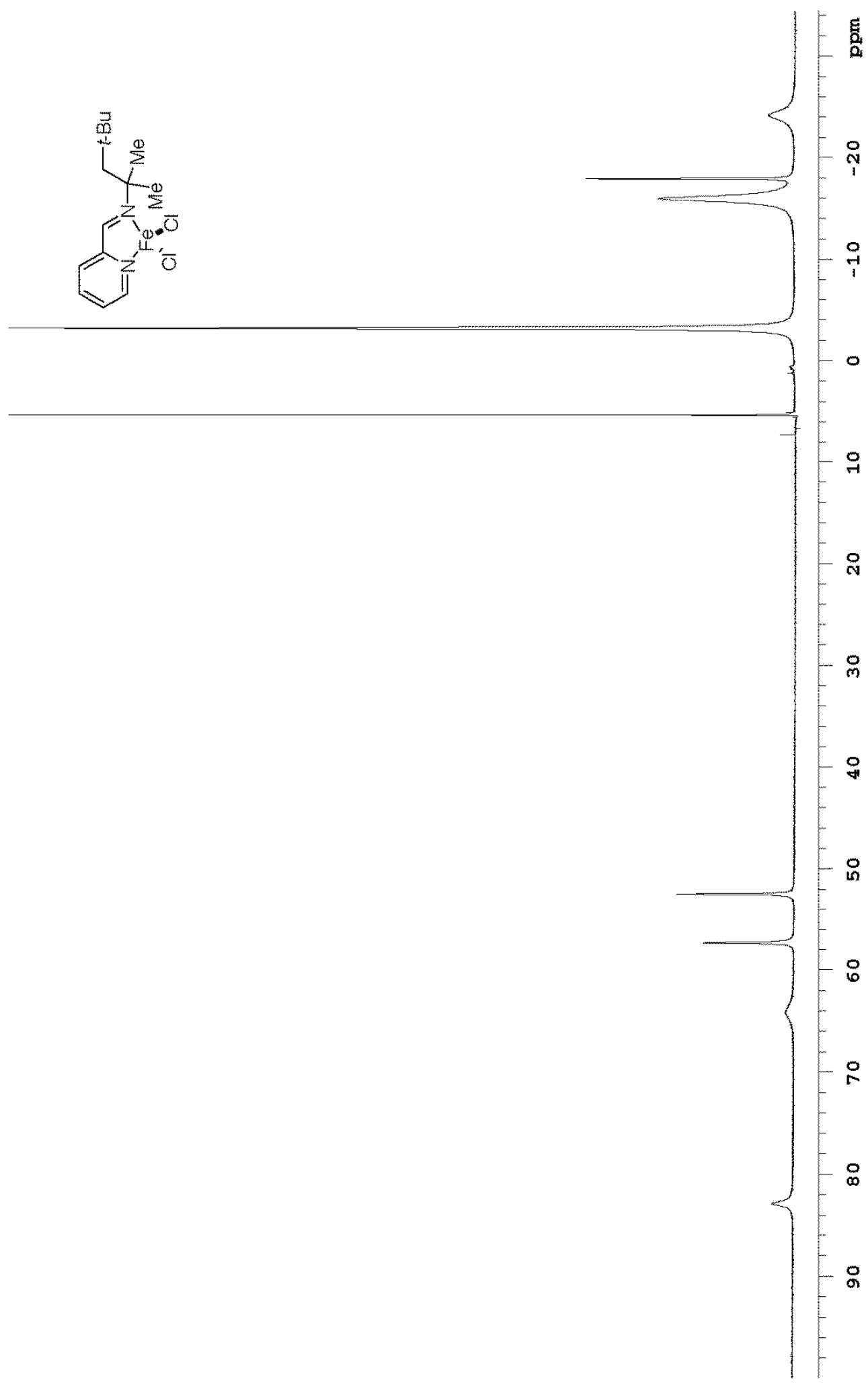

NMR 3: ${ }^{1} \mathrm{H}$ NMR spectrum $\left(500 \mathrm{MHz}, \mathrm{CDCl}_{3}, 25^{\circ} \mathrm{C}\right)$ of $\mathbf{1}$ 


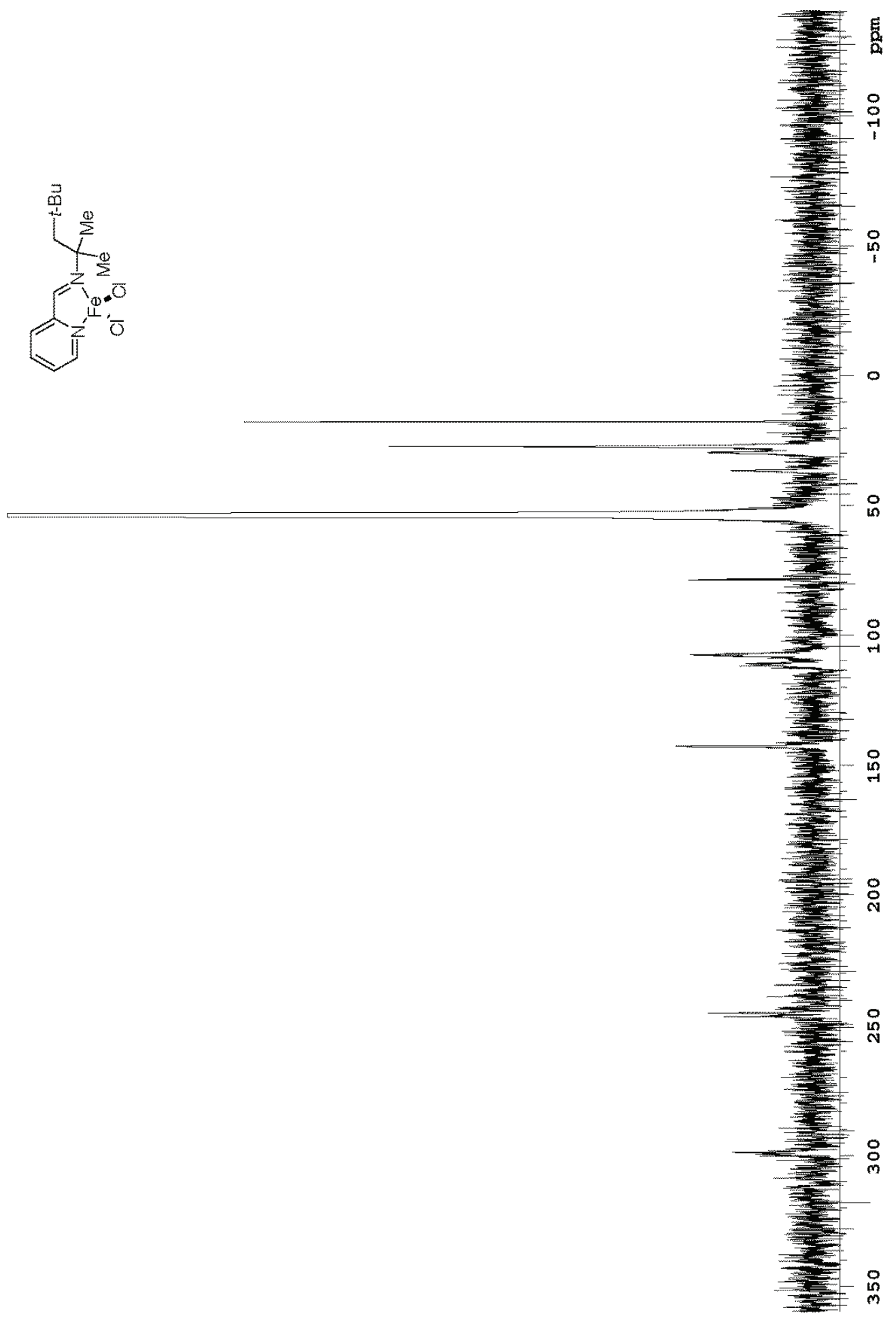

NMR 4: ${ }^{13} \mathrm{C}$ NMR spectrum $\left(125 \mathrm{MHz}, \mathrm{CDCl}_{3}, 25^{\circ} \mathrm{C}\right)$ of $\mathbf{1}$ 


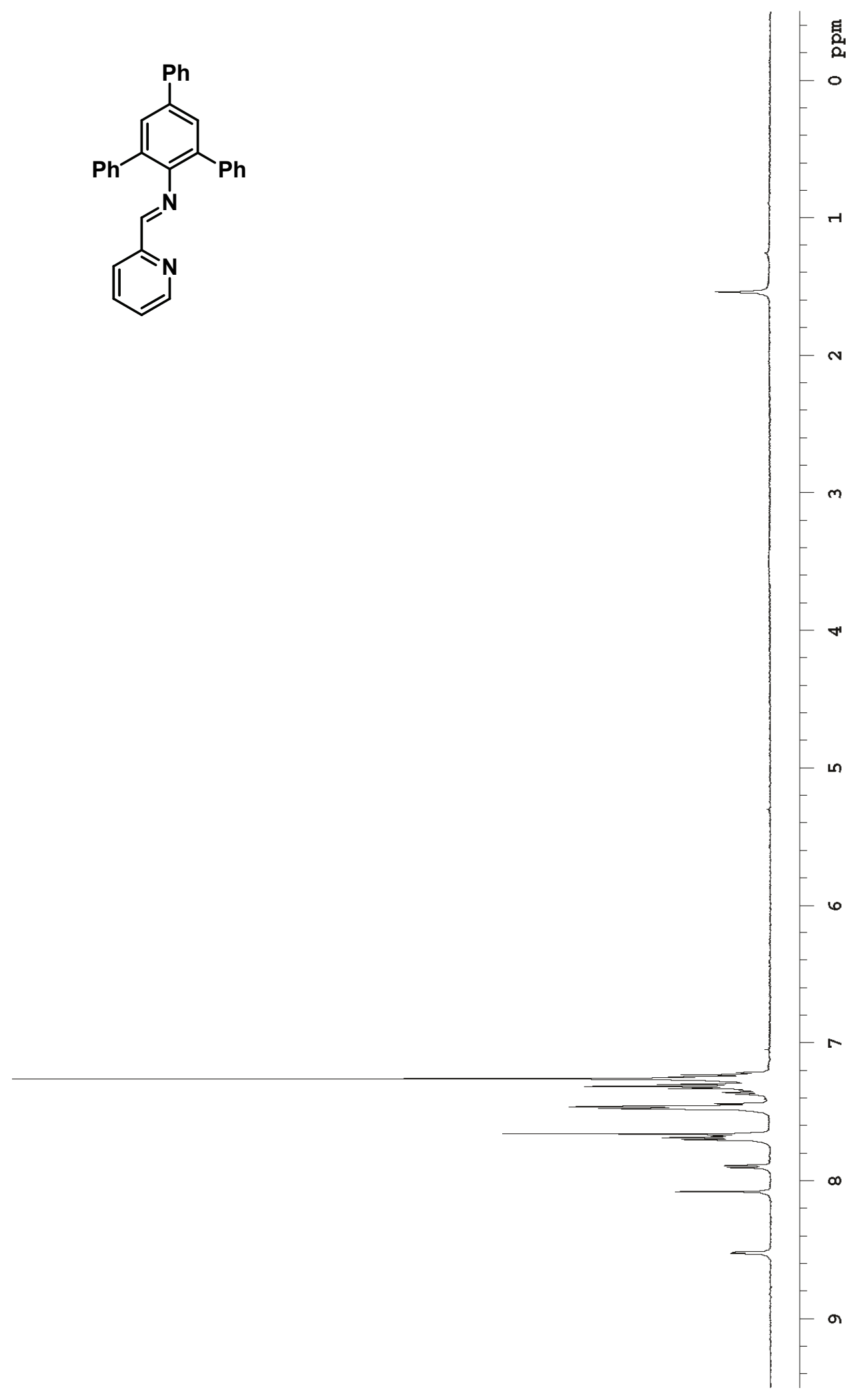

NMR 5: ${ }^{1} \mathrm{H}$ NMR spectrum $\left(500 \mathrm{MHz}, \mathrm{CDCl}_{3}, 25{ }^{\circ} \mathrm{C}\right)$ of $\mathbf{S 2}$ 


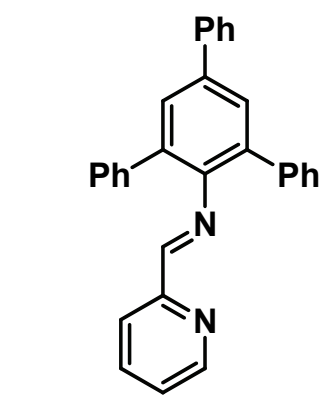

吕

$\circ$

$\stackrel{\circ}{\sim}$

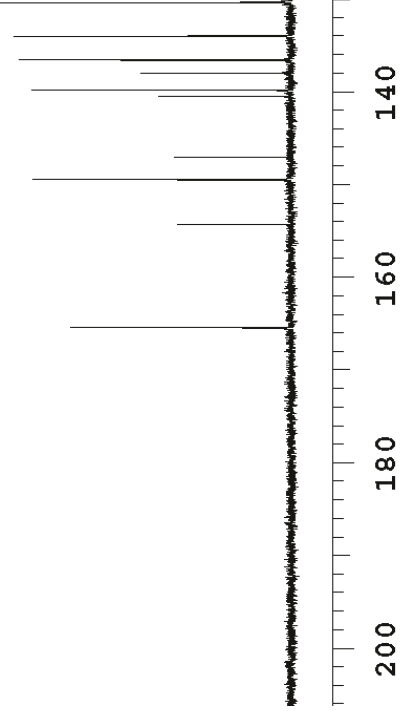

NMR 6: ${ }^{13} \mathrm{C}$ NMR spectrum $\left(125 \mathrm{MHz}, \mathrm{CDCl}_{3}, 25^{\circ} \mathrm{C}\right)$ of $\mathbf{S 2}$ 


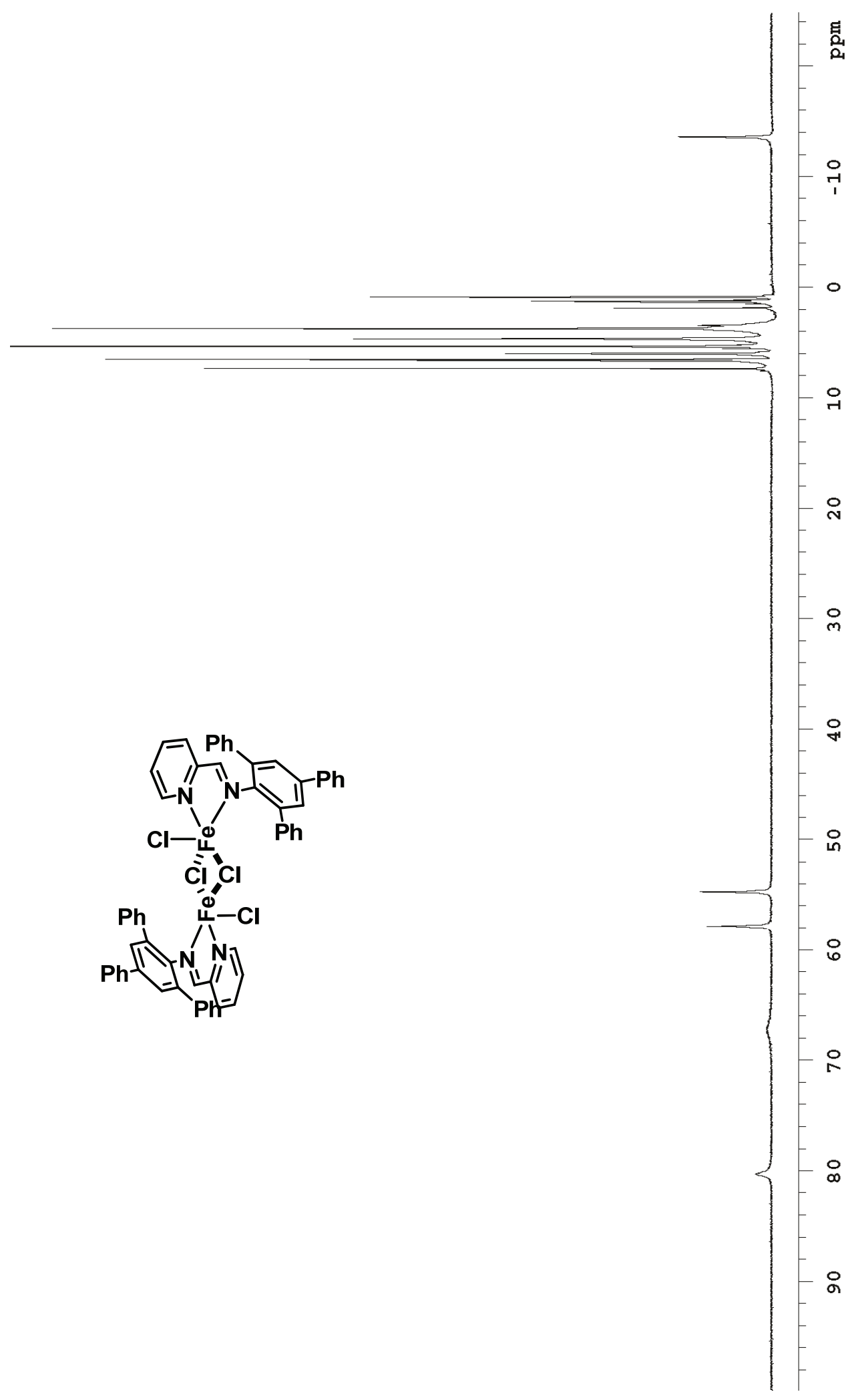

NMR 7: ${ }^{1} \mathrm{H}$ NMR spectrum $\left(500 \mathrm{MHz}, \mathrm{CDCl}_{3}, 25^{\circ} \mathrm{C}\right)$ of 2 


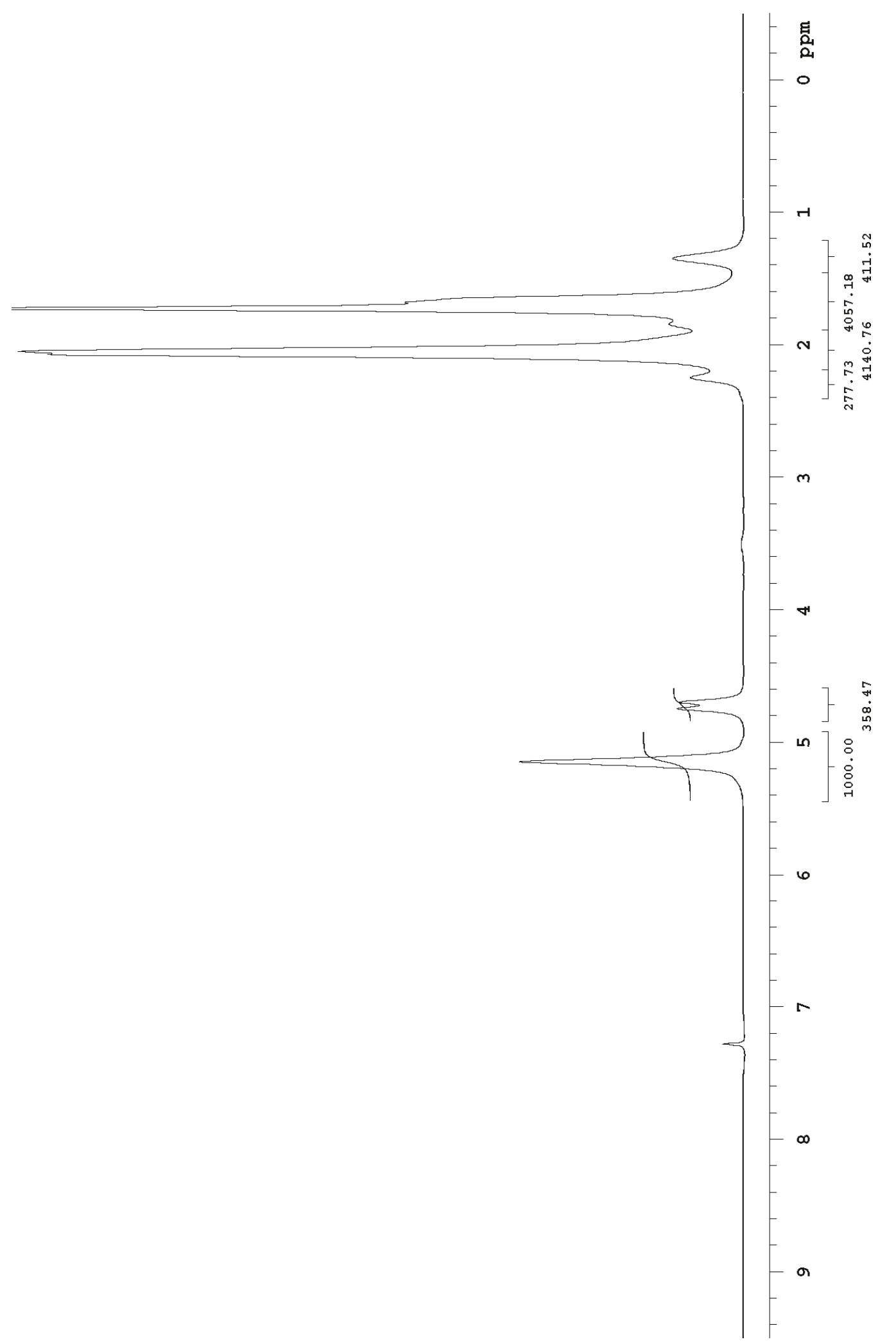

NMR 8: ${ }^{1} \mathrm{H}$ NMR spectrum $\left(500 \mathrm{MHz}, \mathrm{CDCl}_{3}, 25^{\circ} \mathrm{C}\right)$ of cis-1,4-polyisoprene (ex. 5) 


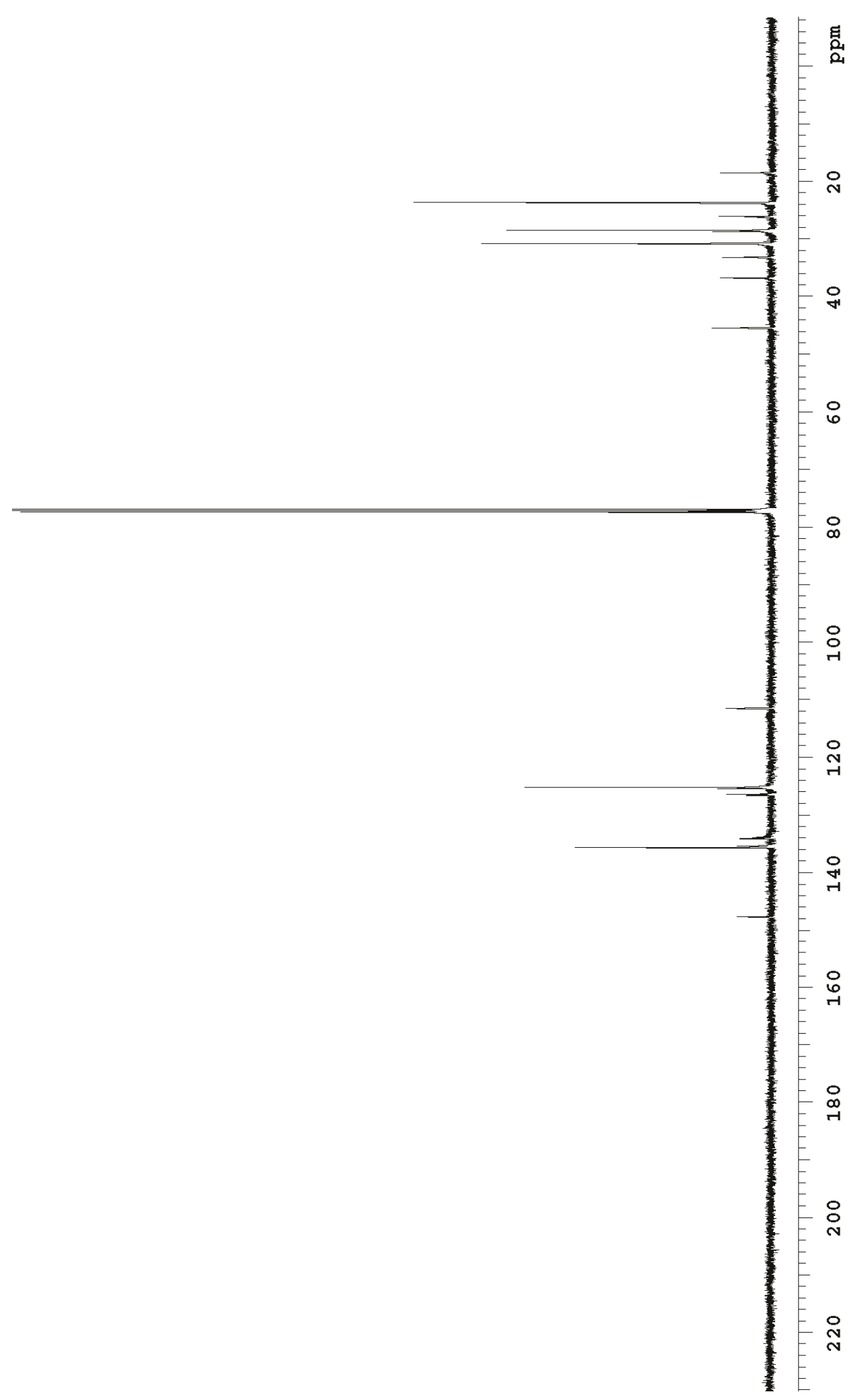

NMR 9: ${ }^{13} \mathrm{C}$ NMR spectrum $\left(125 \mathrm{MHz}, \mathrm{CDCl}_{3}, 25^{\circ} \mathrm{C}\right)$ of cis-1,4-polyisoprene (ex. 5) 


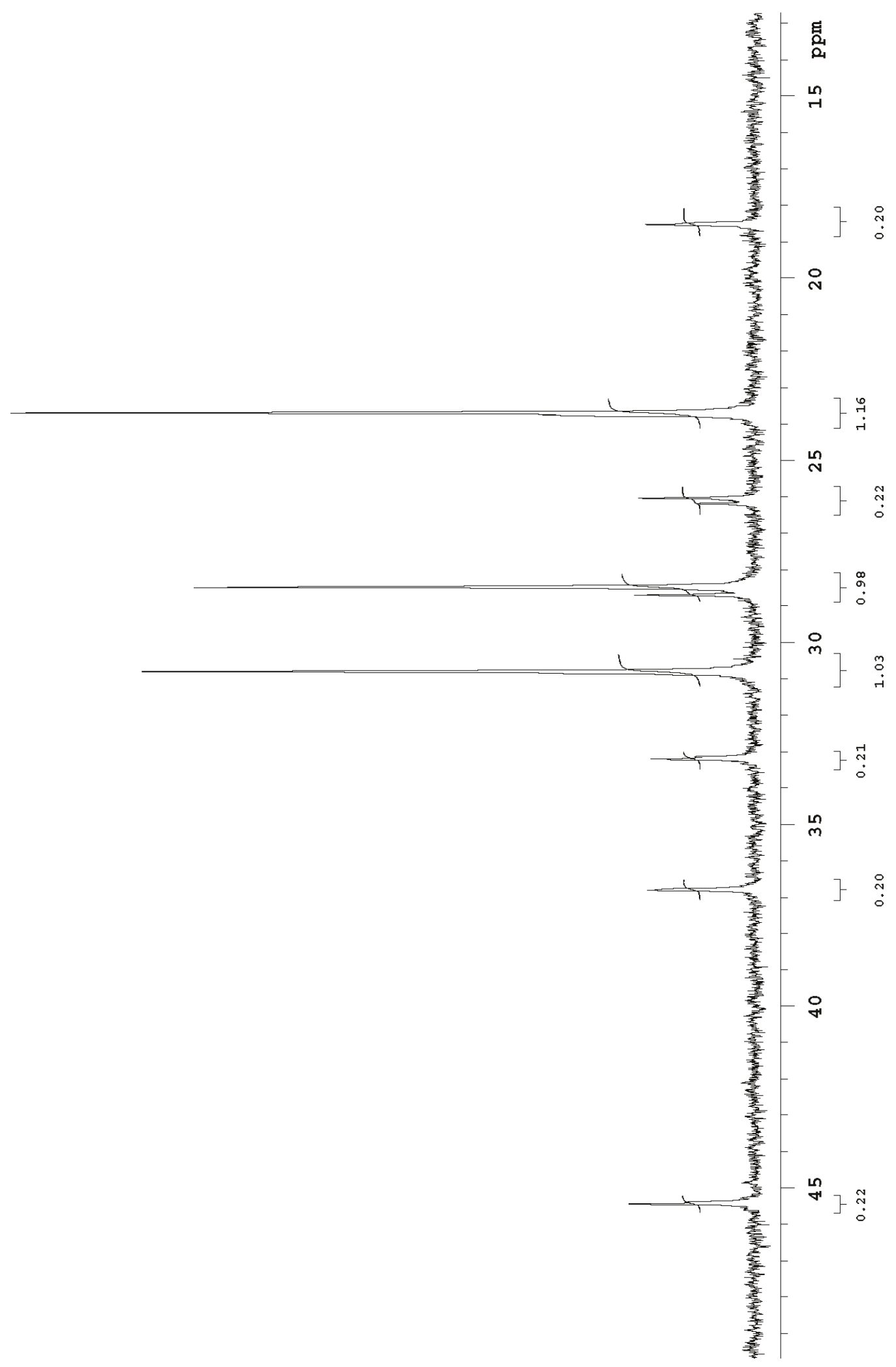

NMR 10: ${ }^{13} \mathrm{C}$ NMR spectrum $\left(125 \mathrm{MHz}, \mathrm{CDCl}_{3}, 25{ }^{\circ} \mathrm{C}\right)$ of cis-1,4-polyisoprene (aliphatic region) 


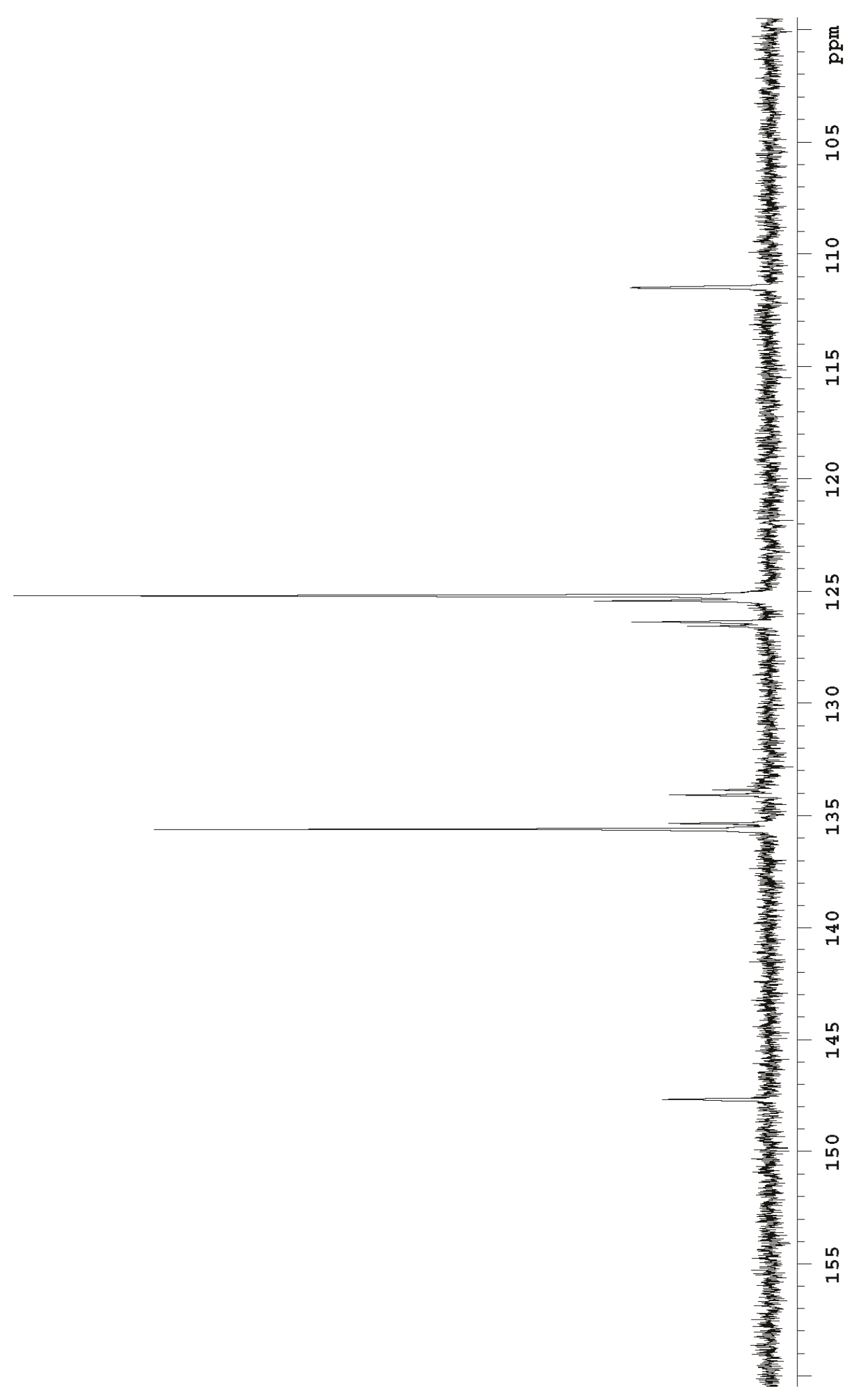

NMR 11: ${ }^{13} \mathrm{C}$ NMR spectrum $\left(125 \mathrm{MHz}, \mathrm{CDCl}_{3}, 25^{\circ} \mathrm{C}\right)$ of cis-1,4-polyisoprene (olefinic region) 


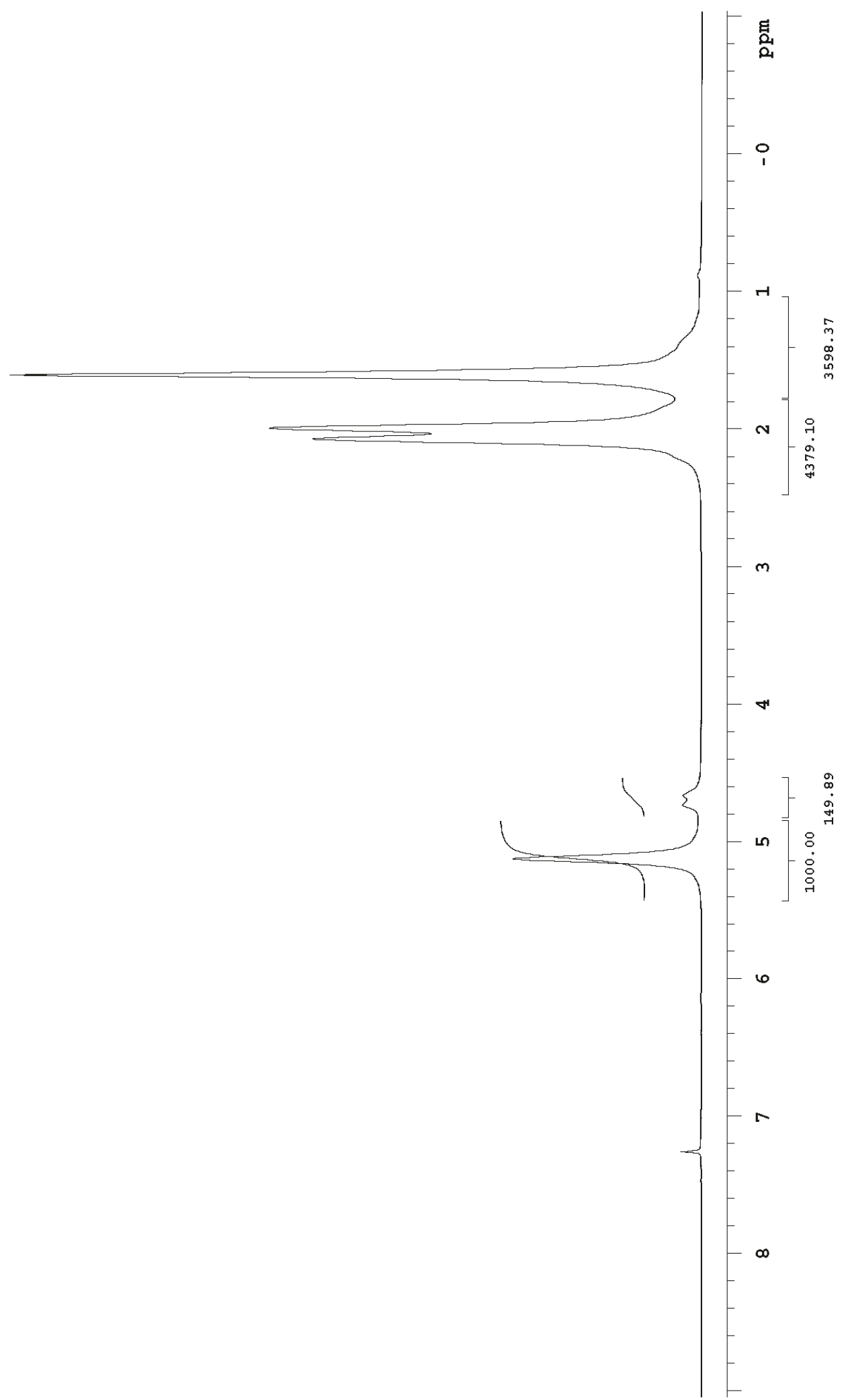

NMR 12: ${ }^{1} \mathrm{H}$ NMR spectrum $\left(500 \mathrm{MHz}, \mathrm{CDCl}_{3}, 25^{\circ} \mathrm{C}\right)$ of trans-1,4-polyisoprene (ex. 2) 


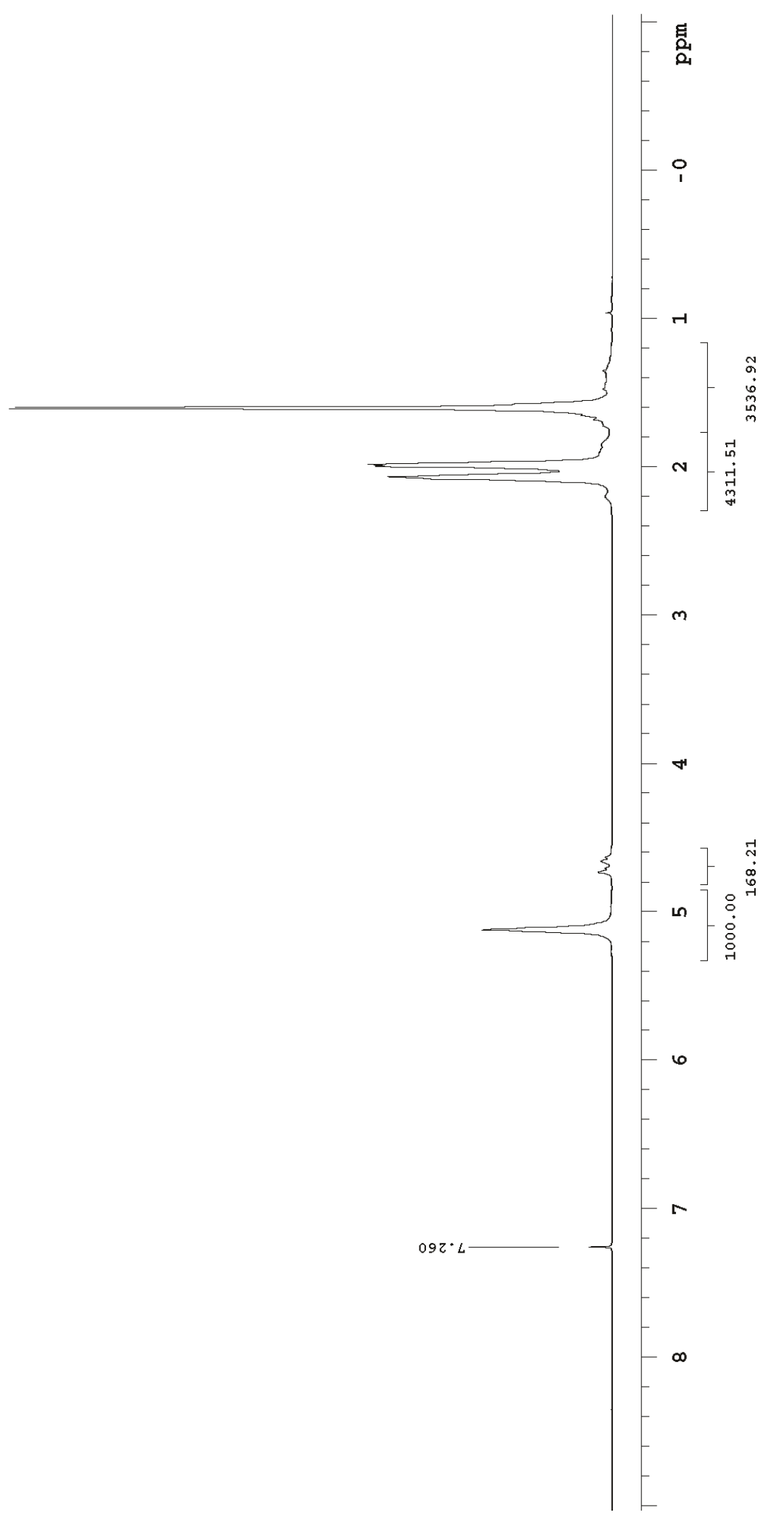

NMR 13: ${ }^{1} \mathrm{H}$ NMR spectrum $\left(500 \mathrm{MHz}, \mathrm{CDCl}_{3}, 25{ }^{\circ} \mathrm{C}\right)$ of trans-1,4-polyisoprene (ex. 1) 


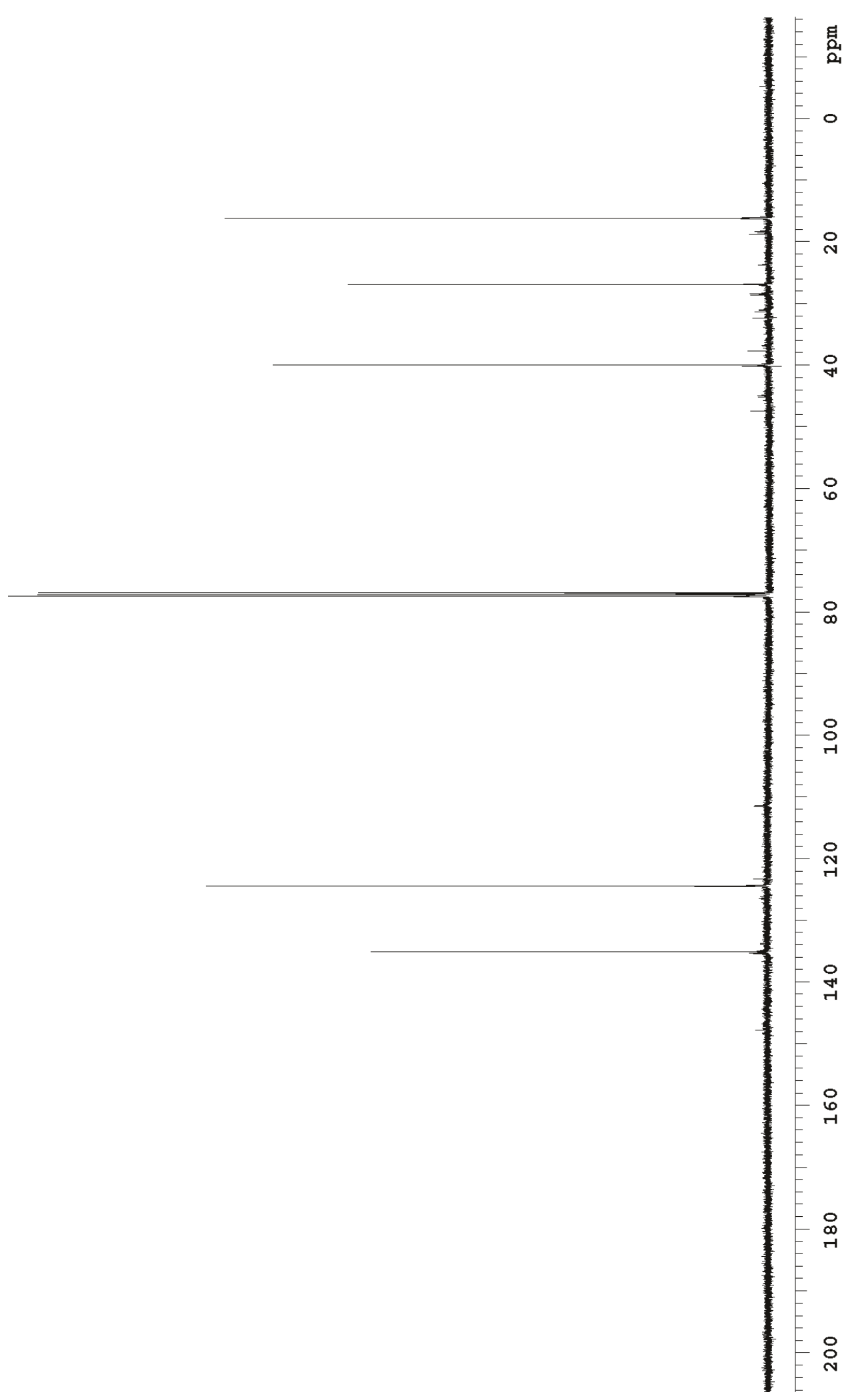

NMR 14: ${ }^{13} \mathrm{C}$ NMR spectrum $\left(125 \mathrm{MHz}, \mathrm{CDCl}_{3}, 25{ }^{\circ} \mathrm{C}\right)$ of trans-1,4-polyisoprene (ex. 2) 


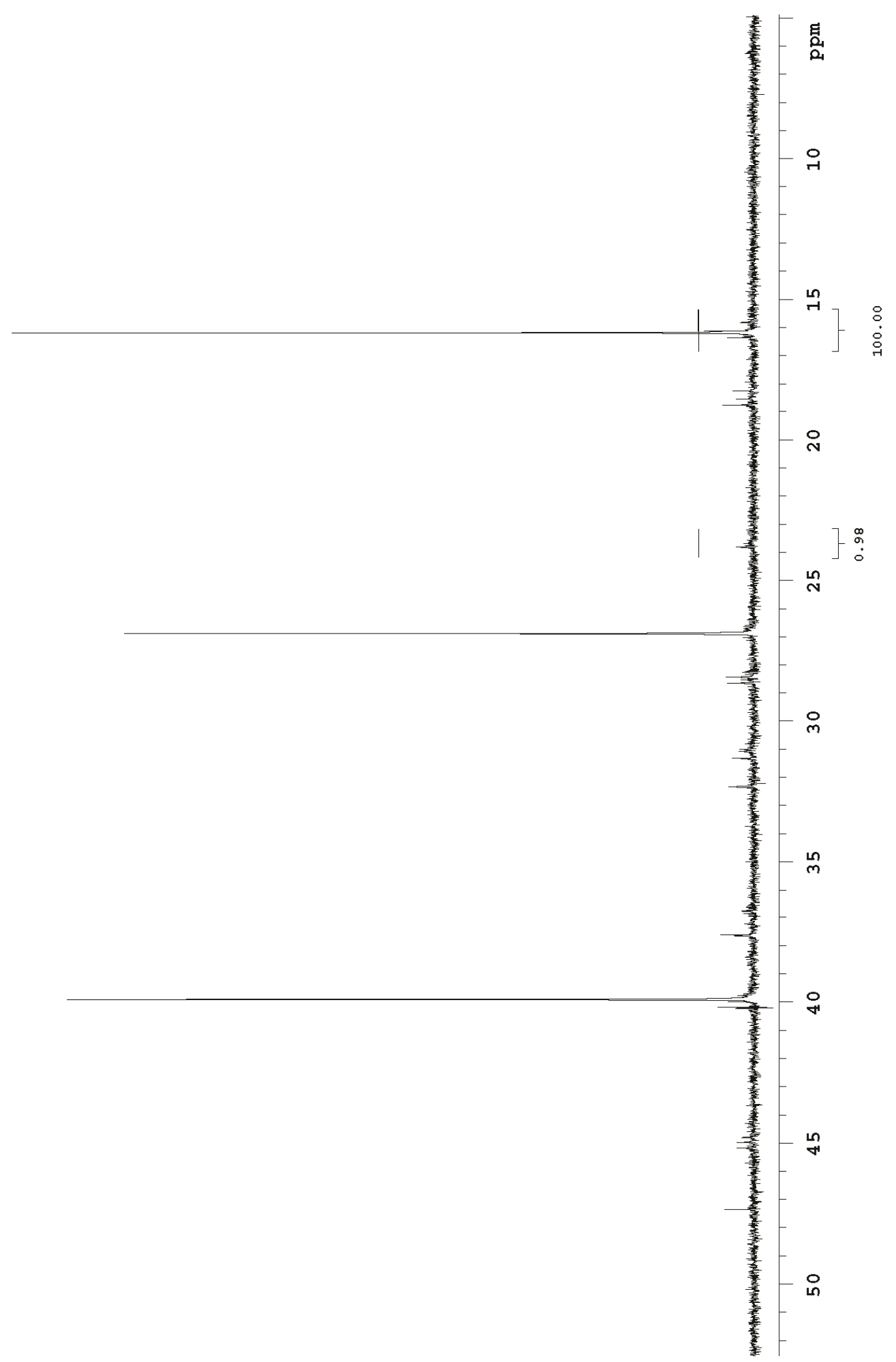

NMR 15: ${ }^{13} \mathrm{C}$ NMR spectrum (125 MHz, $\mathrm{CDCl}_{3}, 25^{\circ} \mathrm{C}$ ) of trans-1,4-polyisoprene (aliphatic region) 


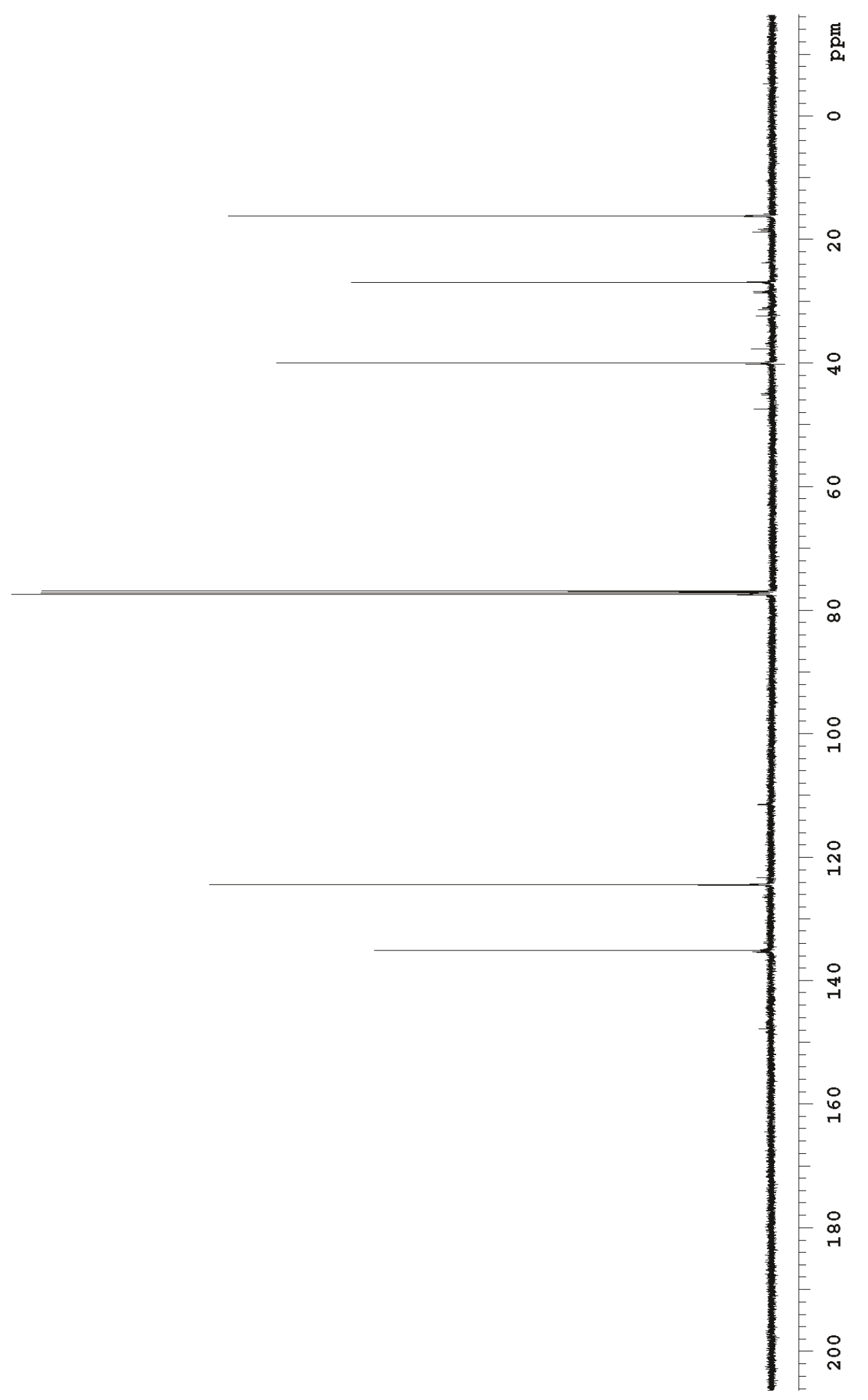

NMR 16: ${ }^{13} \mathrm{C}$ NMR spectrum $\left(125 \mathrm{MHz}, \mathrm{CDCl}_{3}, 25^{\circ} \mathrm{C}\right)$ of trans-1,4-polyisoprene (full) 


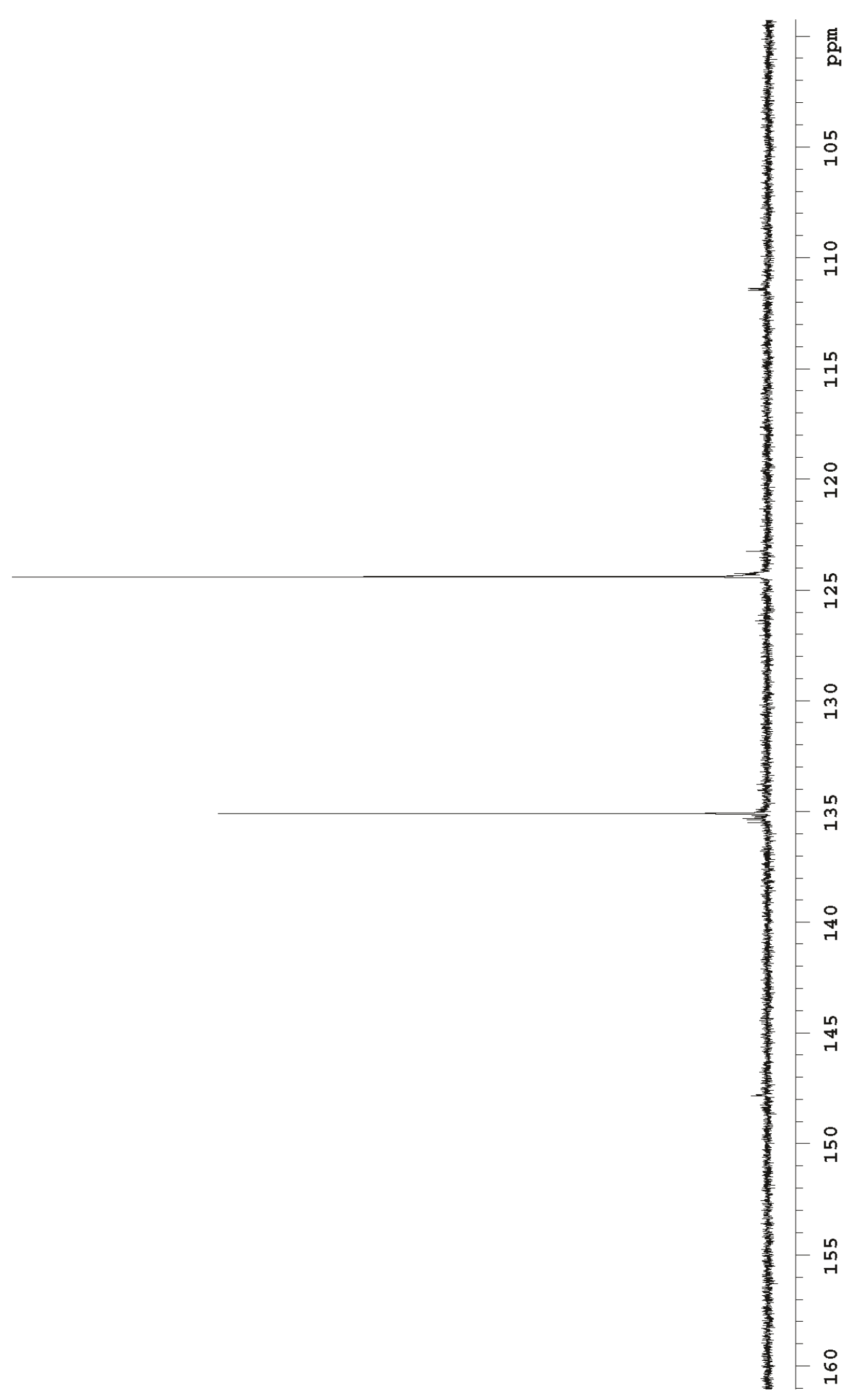

NMR 17: ${ }^{13} \mathrm{C}$ NMR spectrum (125 MHz, $\left.\mathrm{CDCl}_{3}, 25{ }^{\circ} \mathrm{C}\right)$ of trans-1,4-polyisoprene (olefinic region) 


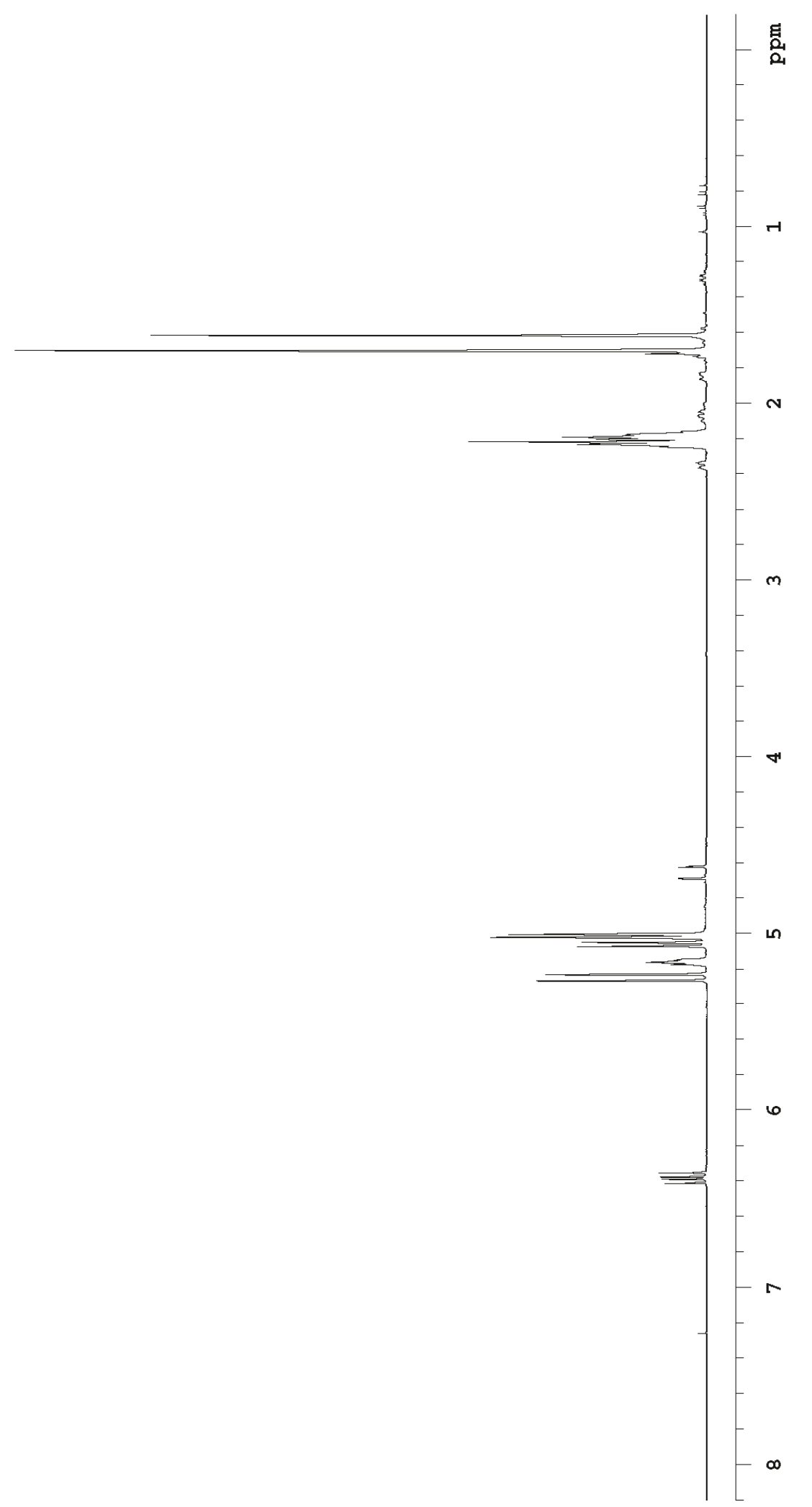

NMR 18: ${ }^{1} \mathrm{H}$ NMR spectrum $\left(500 \mathrm{MHz}, \mathrm{CDCl}_{3}, 25^{\circ} \mathrm{C}\right)$ of $\boldsymbol{\beta}$-myrcene 


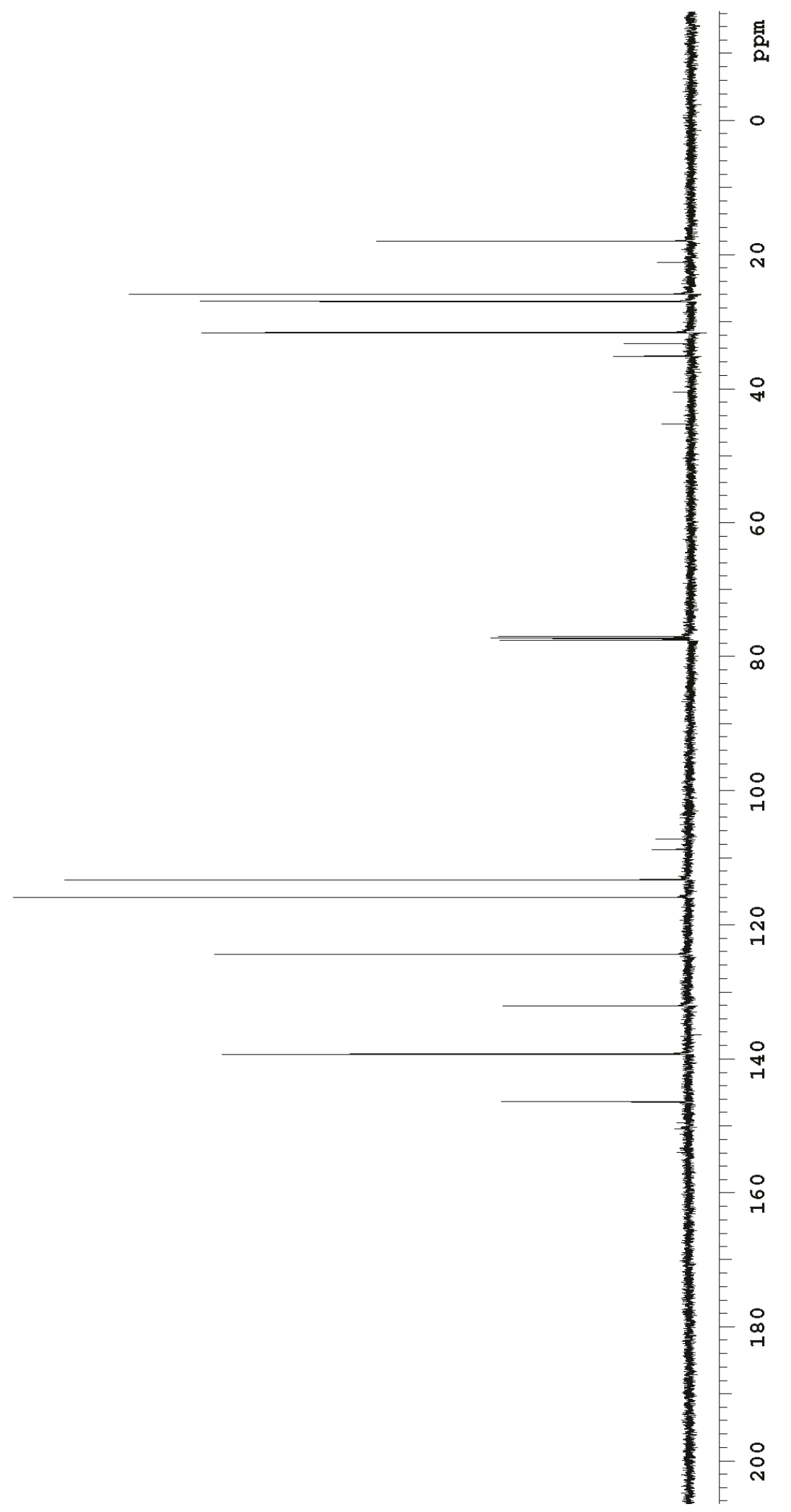

NMR 19: ${ }^{13} \mathrm{C}$ NMR spectrum $\left(125 \mathrm{MHz}, \mathrm{CDCl}_{3}, 25^{\circ} \mathrm{C}\right)$ of $\boldsymbol{\beta}$-myrcene 


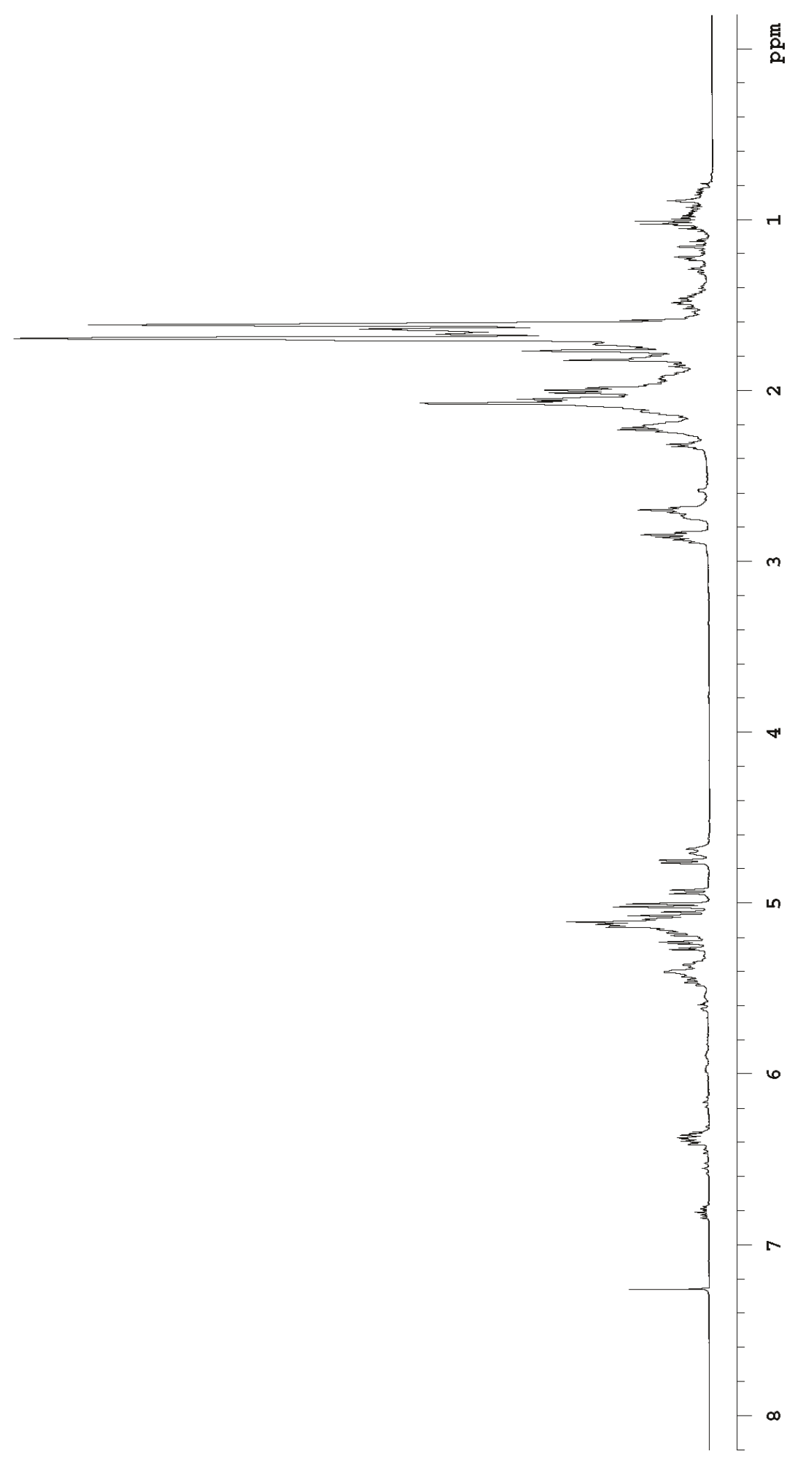

NMR 20: ${ }^{1} \mathrm{H}$ NMR spectrum $\left(500 \mathrm{MHz}, \mathrm{CDCl}_{3}, 25^{\circ} \mathrm{C}\right)$ of farnesene (mixture) 


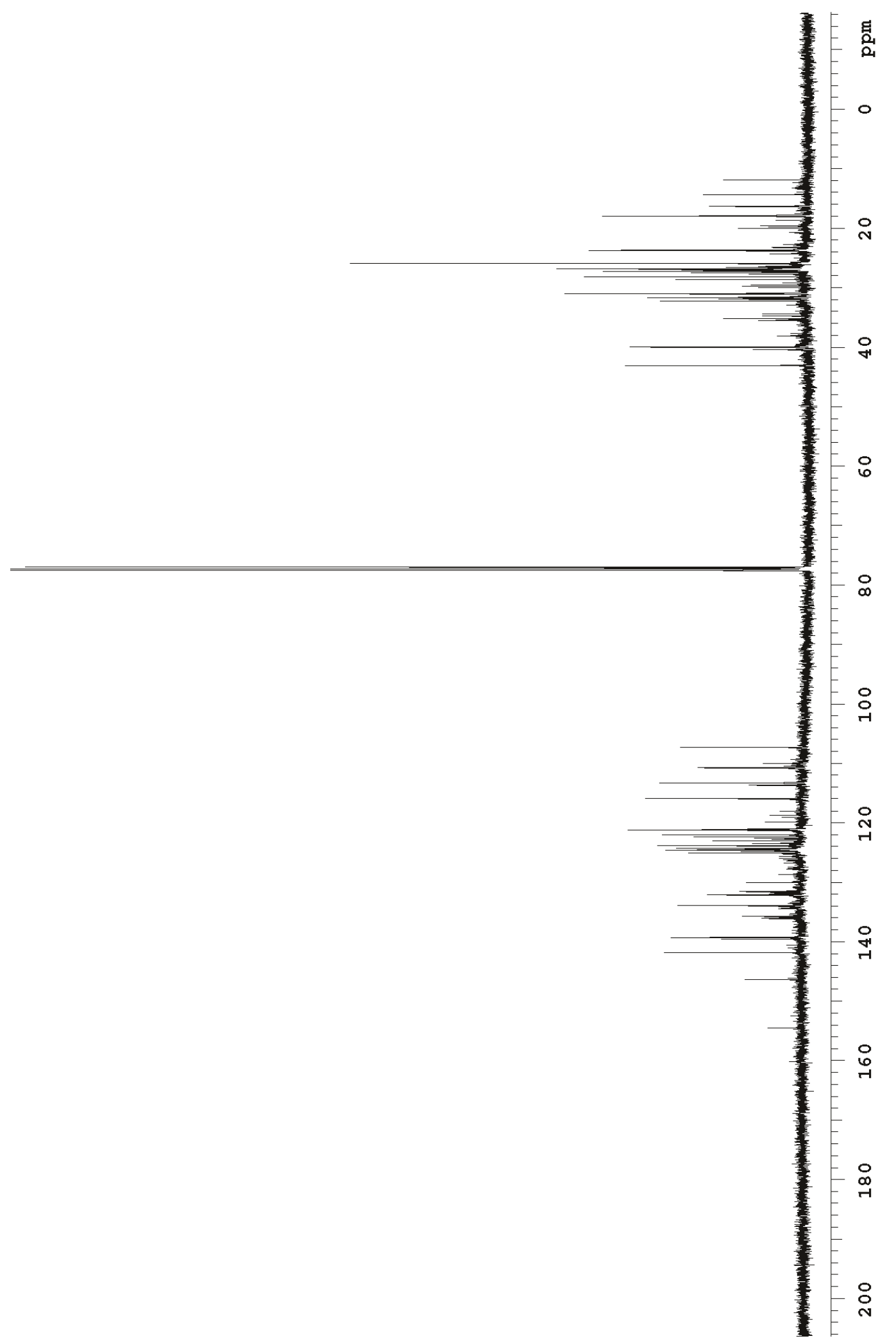

NMR 21: ${ }^{13} \mathrm{C}$ NMR spectrum $\left(125 \mathrm{MHz}, \mathrm{CDCl}_{3}, 25^{\circ} \mathrm{C}\right)$ of farnesene (mixture) 


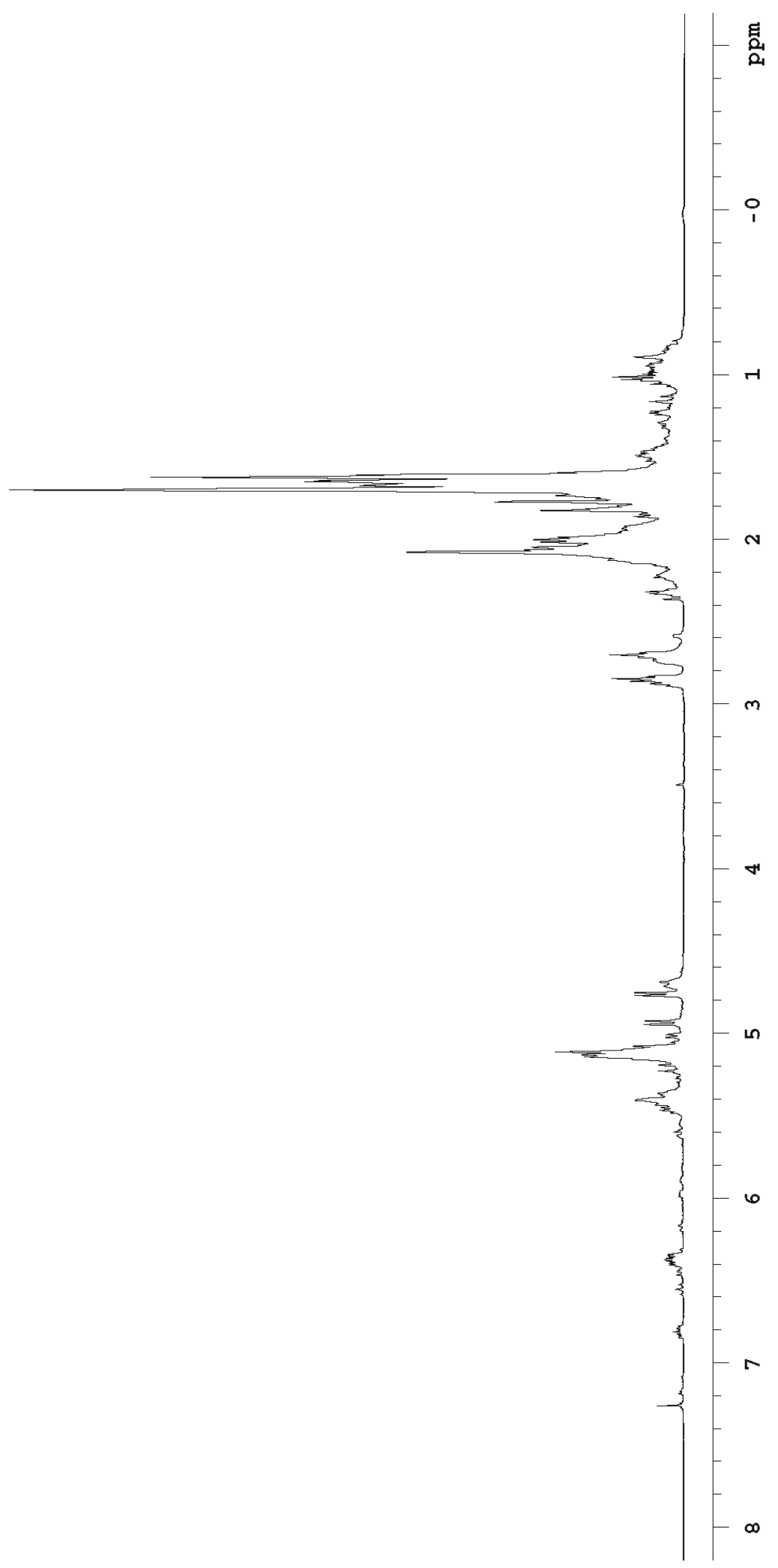

NMR 22: ${ }^{1} \mathrm{H}$ NMR spectrum (500 MHz, $\mathrm{CDCl}_{3}, 25^{\circ} \mathrm{C}$ ) of farnesene ( $\boldsymbol{\alpha}$-isomer) (ex. 10) 


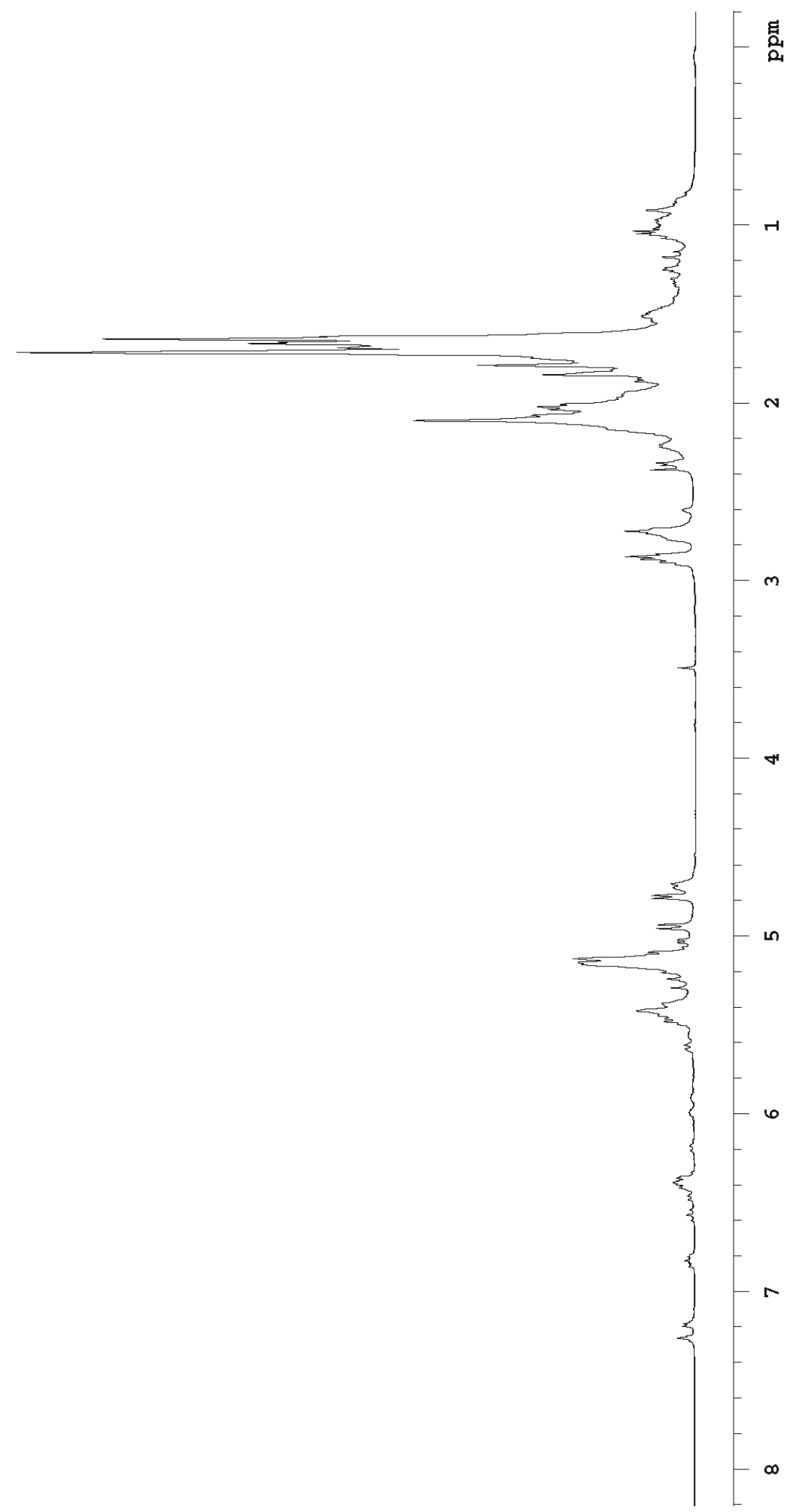

NMR 23: ${ }^{1} \mathrm{H}$ NMR spectrum $\left(500 \mathrm{MHz}, \mathrm{CDCl}_{3}, 25^{\circ} \mathrm{C}\right.$ ) of farnesene ( $\boldsymbol{\alpha}$-isomer) (ex. 9) 


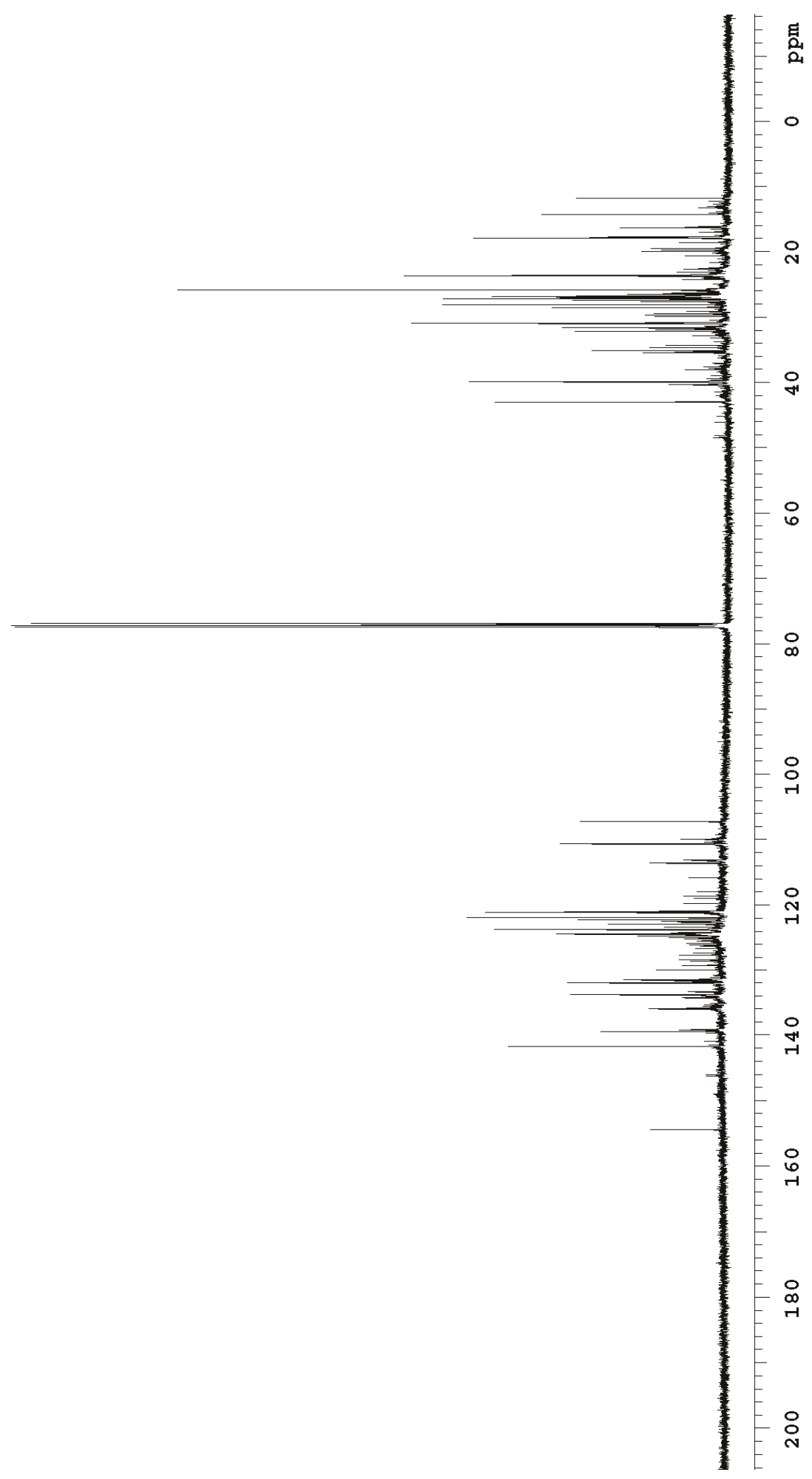

NMR 24: ${ }^{13} \mathrm{C}$ NMR spectrum $\left(125 \mathrm{MHz}, \mathrm{CDCl}_{3}, 25{ }^{\circ} \mathrm{C}\right.$ ) of farnesene ( $\alpha$-isomer) 


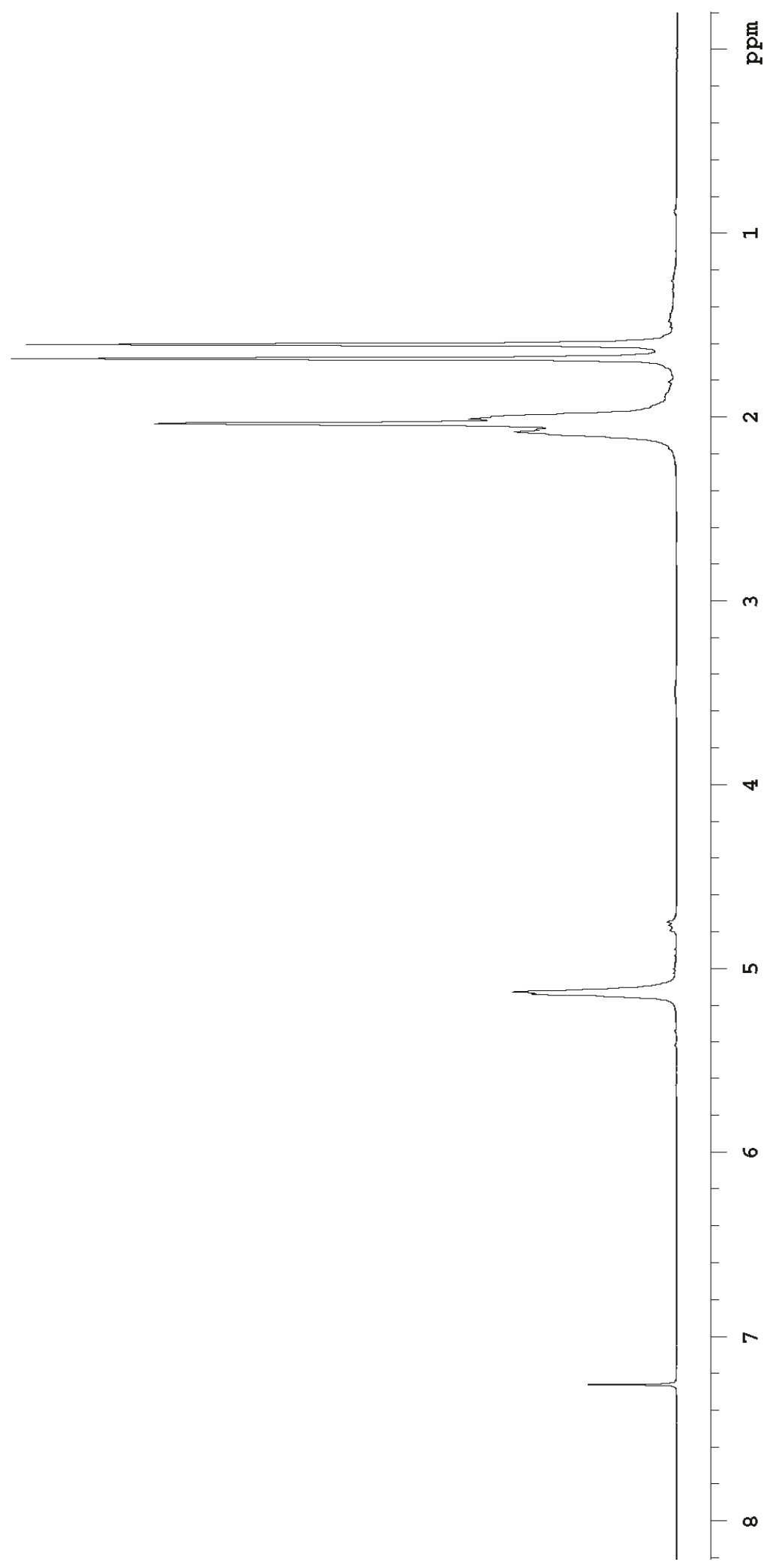

NMR 25: ${ }^{1} \mathrm{H}$ NMR spectrum $\left(500 \mathrm{MHz}, \mathrm{CDCl}_{3}, 25^{\circ} \mathrm{C}\right)$ of trans-1,4-poly- $\boldsymbol{\beta}$-myrcene (ex. 9) 


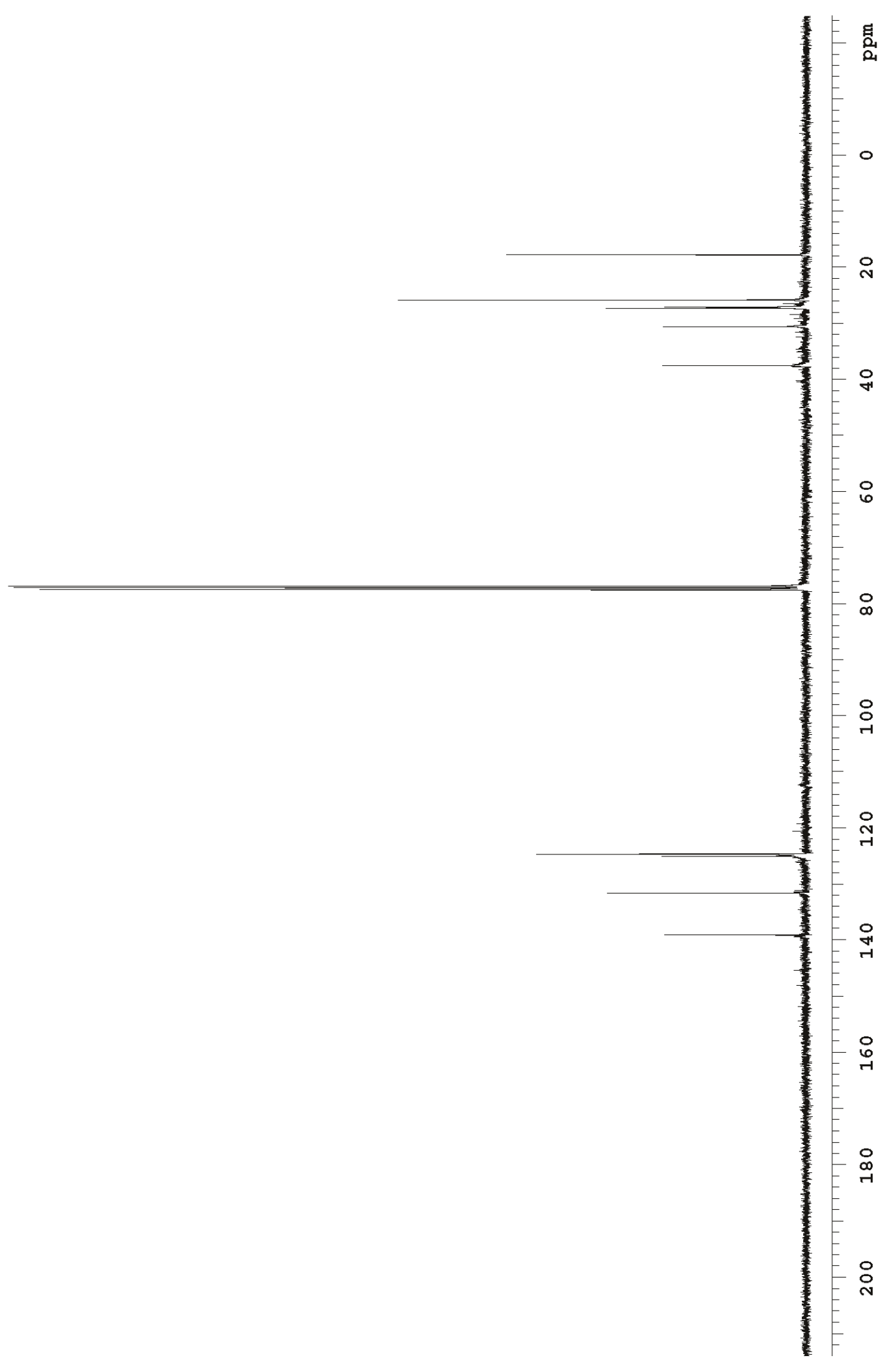

NMR 26: ${ }^{13} \mathrm{C}$ NMR spectrum (125 MHz, $\left.\mathrm{CDCl}_{3}, 25{ }^{\circ} \mathrm{C}\right)$ of trans-1,4-poly- $\boldsymbol{\beta}$-myrcene (ex. 9) 


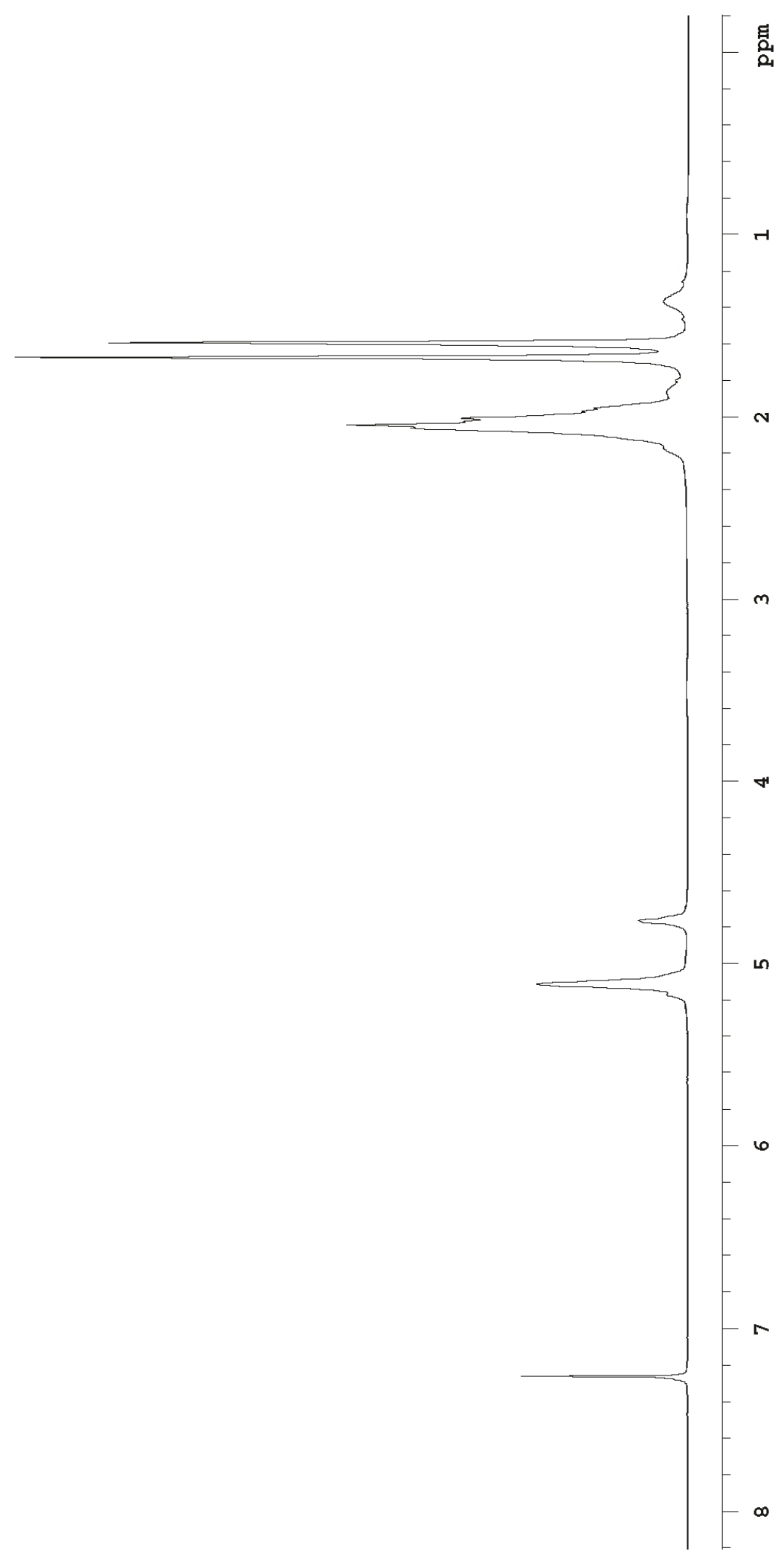

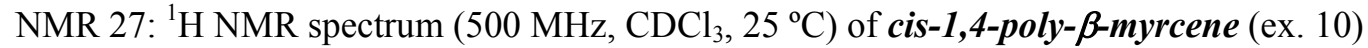




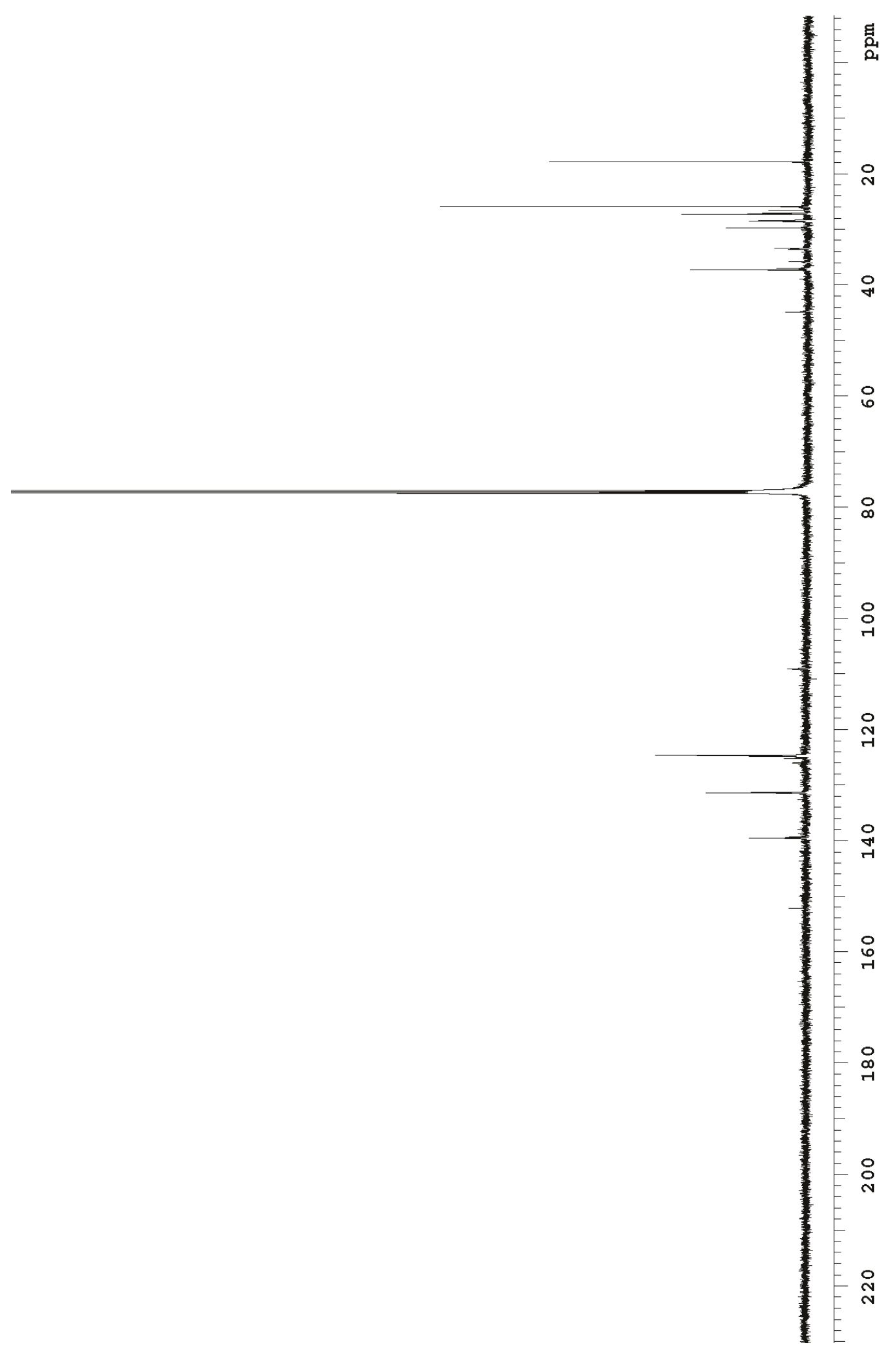

NMR 28: ${ }^{13} \mathrm{C}$ NMR spectrum $\left(125 \mathrm{MHz}, \mathrm{CDCl}_{3}, 25{ }^{\circ} \mathrm{C}\right)$ of $\boldsymbol{c i s - 1 , 4 - p o l y - \beta}$-myrcene (ex. 10) 


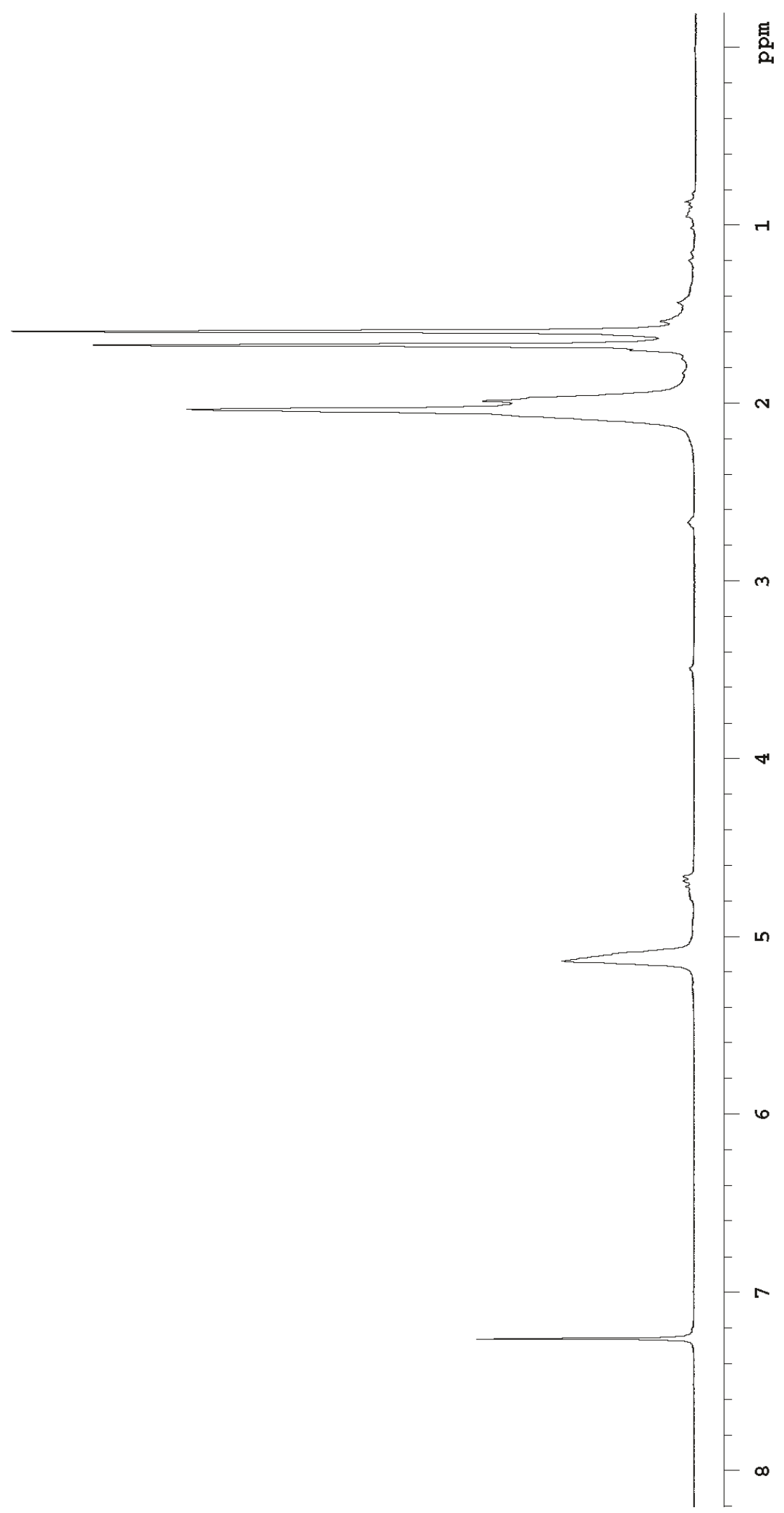

NMR 29: ${ }^{1} \mathrm{H}$ NMR spectrum $\left(500 \mathrm{MHz}, \mathrm{CDCl}_{3}, 25^{\circ} \mathrm{C}\right)$ of trans-1,4-poly- $\boldsymbol{\beta}$-farnesene (ex. 11) 


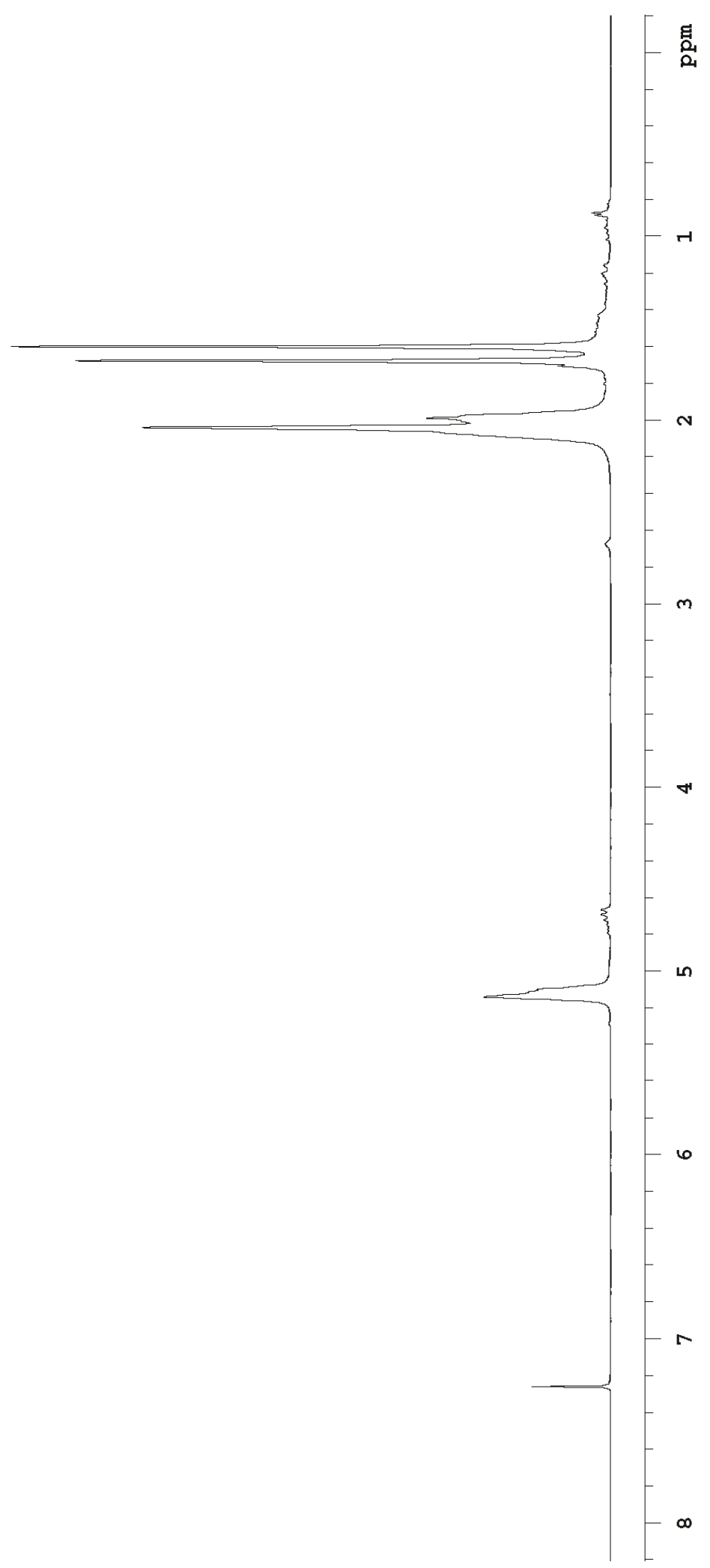

NMR 30: ${ }^{1} \mathrm{H}$ NMR spectrum $\left(500 \mathrm{MHz}, \mathrm{CDCl}_{3}, 25^{\circ} \mathrm{C}\right)$ of trans-1,4-poly- $\boldsymbol{\beta}$-farnesene (ex. 11) 


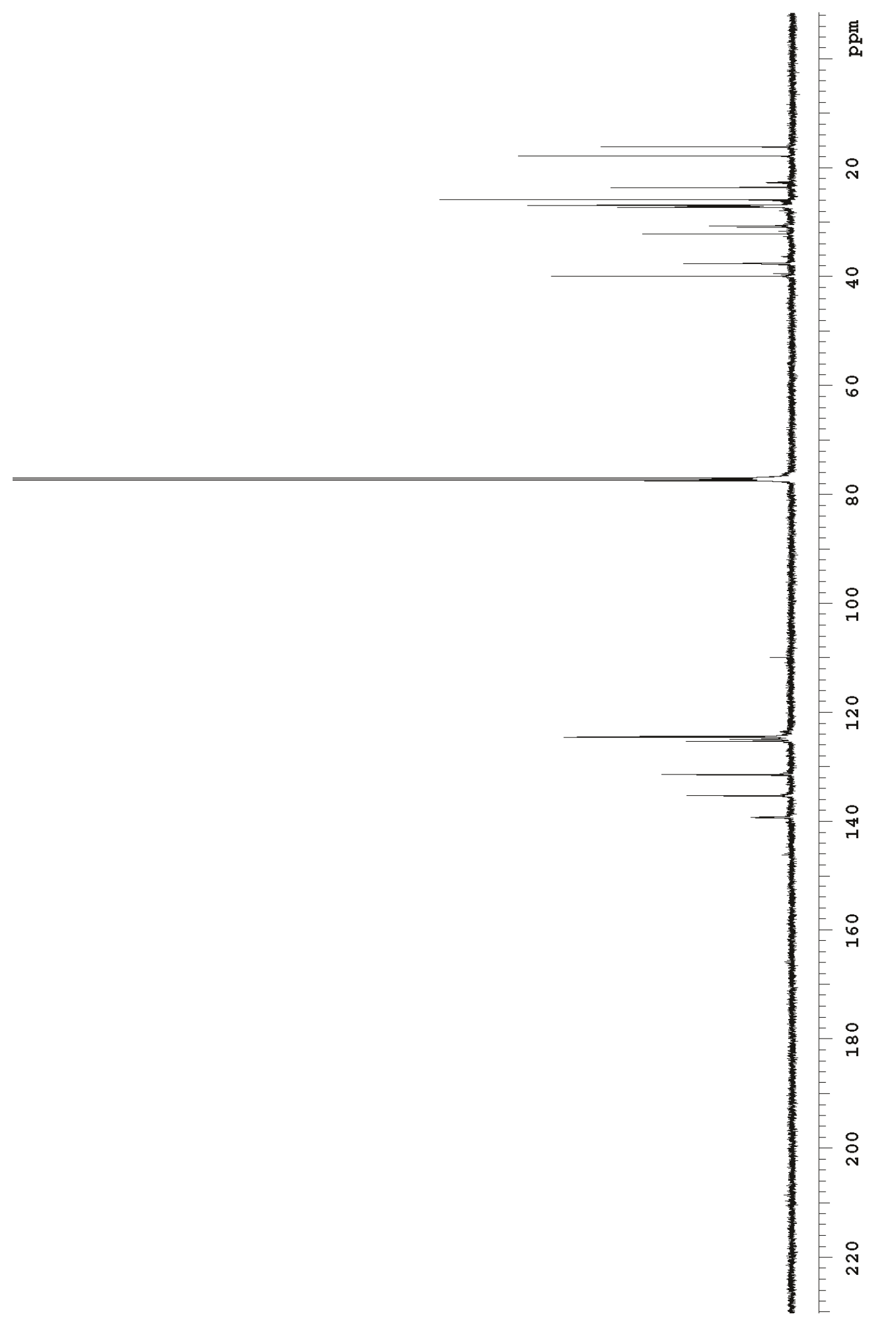

NMR 31: ${ }^{13} \mathrm{C}$ NMR spectrum $\left(125 \mathrm{MHz}, \mathrm{CDCl}_{3}, 25^{\circ} \mathrm{C}\right)$ of trans-1,4-poly- $\boldsymbol{\beta}$-farnesene (ex. 11) 


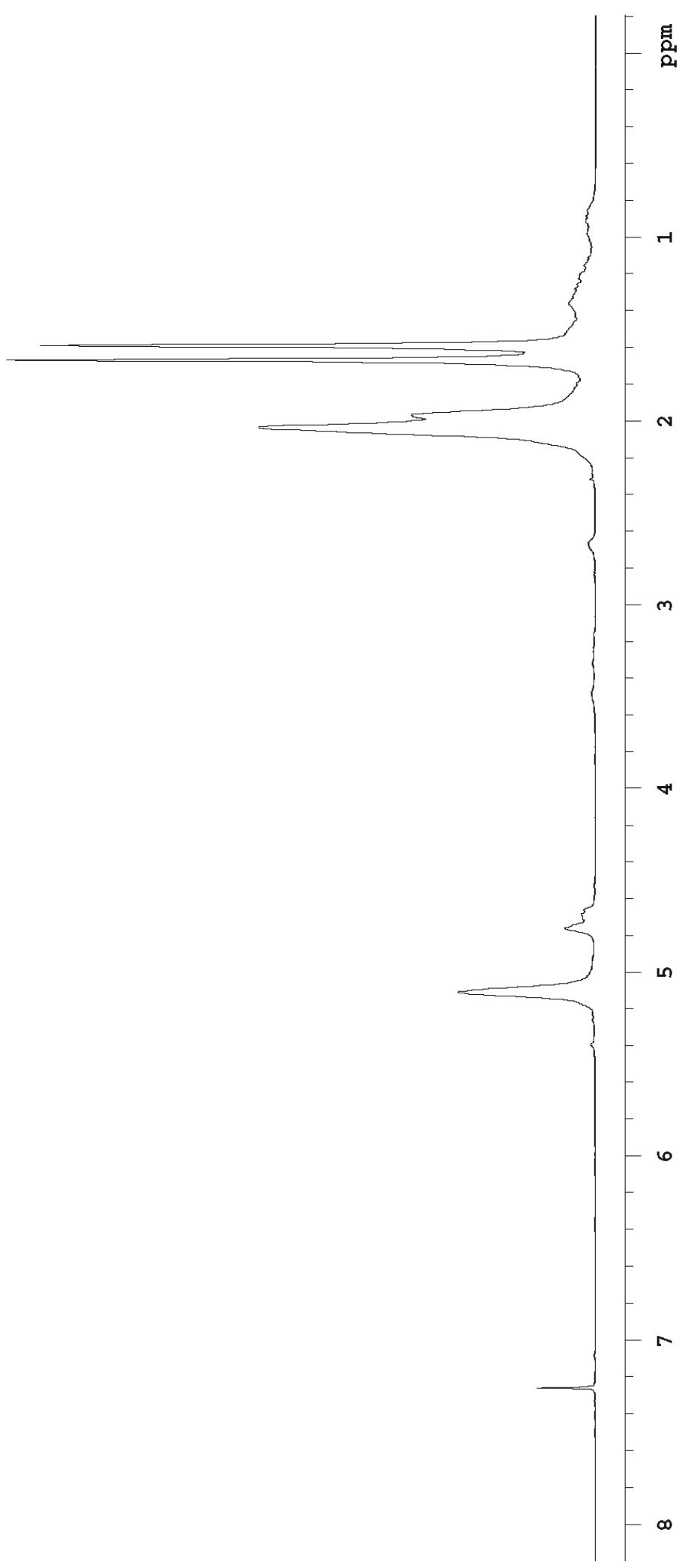

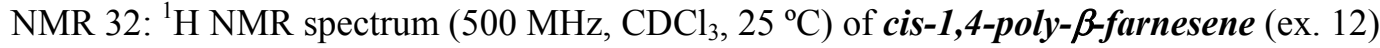




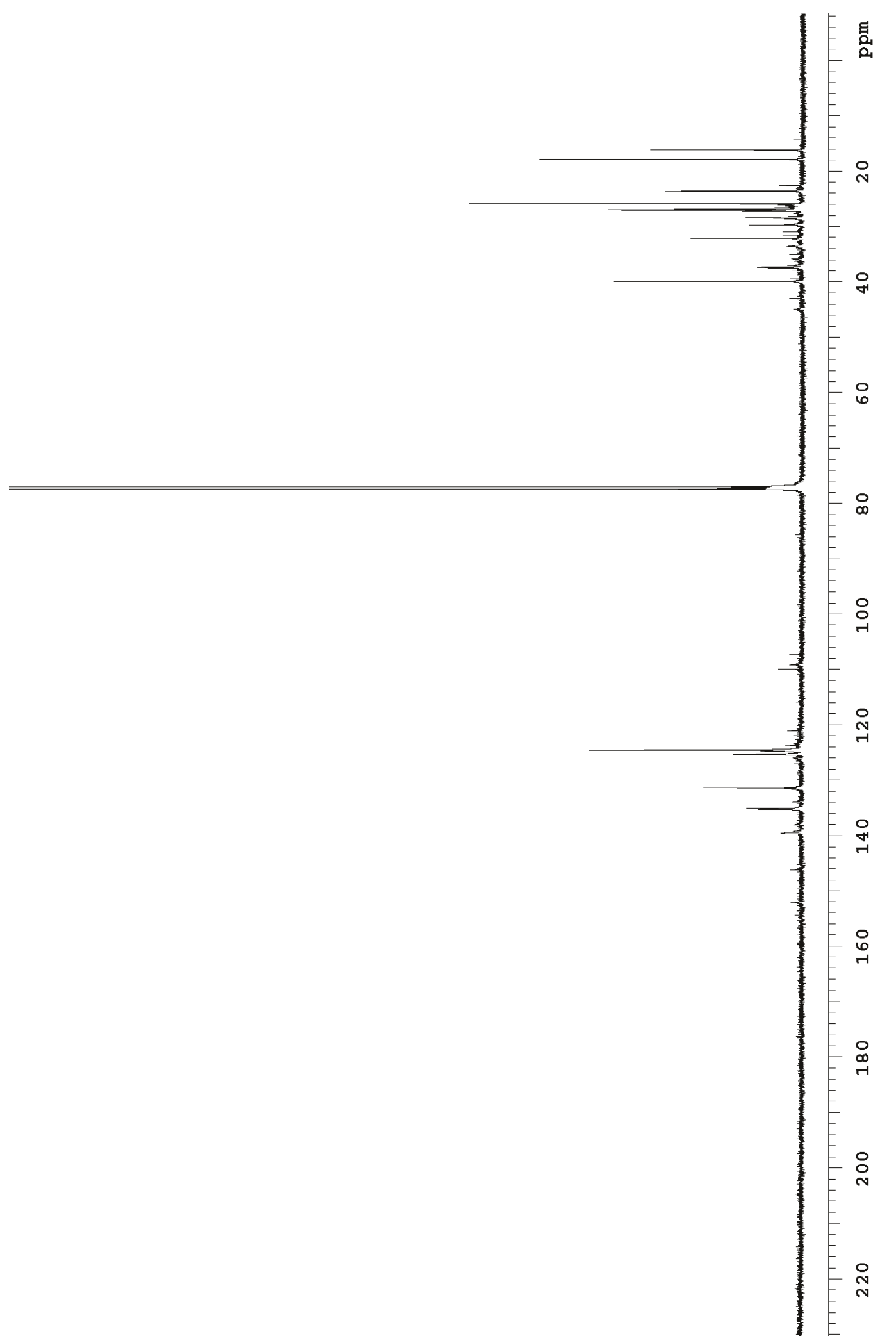

NMR 33: ${ }^{13} \mathrm{C}$ NMR spectrum $\left(125 \mathrm{MHz}, \mathrm{CDCl}_{3}, 25^{\circ} \mathrm{C}\right.$ ) of cis-1,4-poly- $\beta$-farnesene (ex. 12) 


\section{References}

1) Shriver, D. F.; Drezdon, M. A. Inert-Atmosphere Glove Boxes. The Manipulation of AirSensitive Compounds, 2nd ed.; John Wiley \& Sons: New York, 1986; pp. 45-67.

2) Pangborn, A. B.; Giardello, M. A.; Grubbs, R. H.; Rosen, R. K.; Timmers, F. J. Organometallics 1996, 15, 1518-1520.

3) Still, W. C.; Kahn, M.; Mitra, A. J. Org. Chem. 1978, 43, 2923-2925.

4) Armarego, W. L. F.; Chai, C. L. L. Purification of Laboratory Chemicals, 5th ed.; Butterworth Henemann: Amsterdam, 2003; pp. 29-30.

5) Evans, D. F. J. Chem. Soc. 1959, 2003-2005.

6) W. Gao, D. Cui J. Am. Chem. Soc. 2008, 130, 4984-4991

7) D. Cui et al. Organometallics 2010, 29, 2186-2193

8) K. Lv, D. Cui Organometallics 2010, 29, 2987-2993

9) S. Zhang, Z. Hou, X. Li et al. Organometallics 2011, 30, 160-170

10) S. V. Kostjuk et al Macromolecules 2011, 44, 1372-1384

11) Peruch et al. J. Polym. Sci. Part A: Polym. Chem. 2011, 49, 4948-4954

12) Peruch et al. Polym. Int. 2012, 61, 149-156 